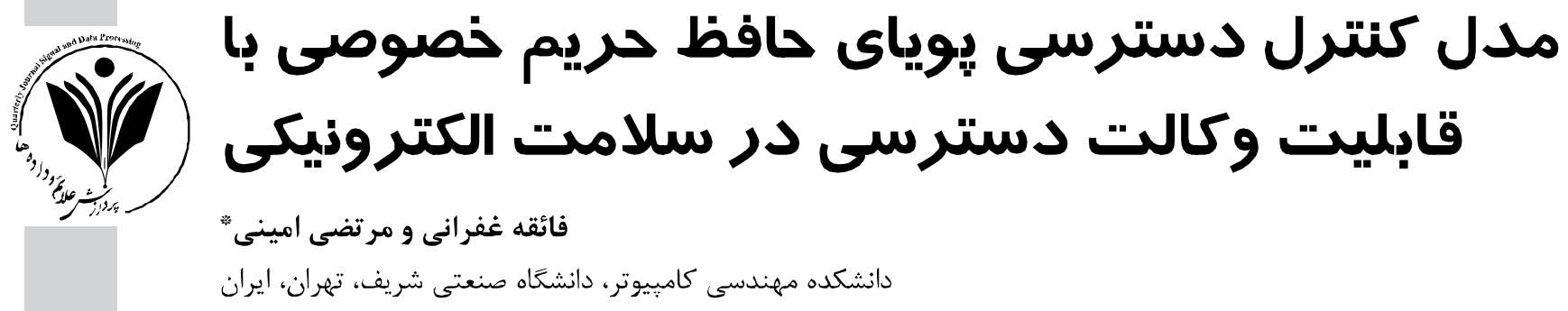

$$
\begin{aligned}
& \text { جكبده } \\
& \text { كسترش استفاده از فناورى اطلاعات و بهطور خاص اينترنت اشيا در حوزه سلامت الكترونيكى، مسائل مختلفى را بههمراه دارد كه از }
\end{aligned}
$$

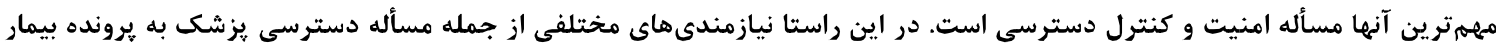

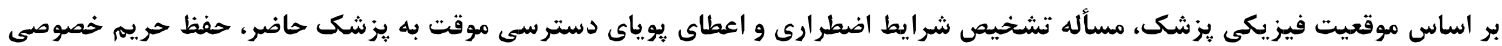

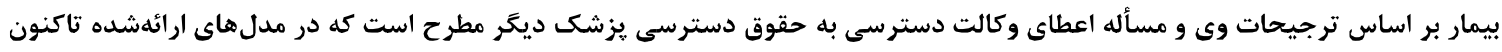

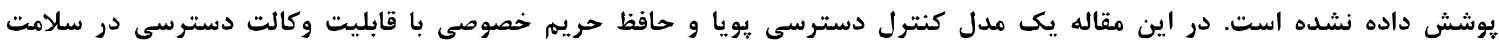

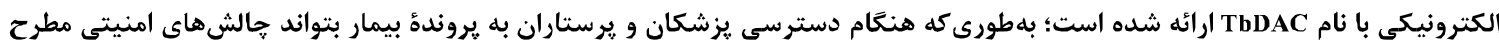

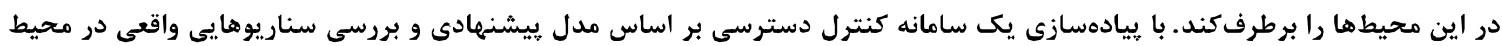

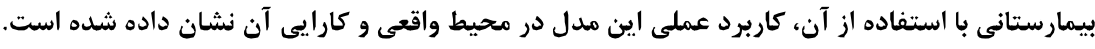

$$
\begin{aligned}
& \text { وازَّان كليدى: سلامت الكترونيكى، اينترنت اشيا، كنترل دسترسى يويا، حفظ حريم خصوصى، وكالت دسترسى }
\end{aligned}
$$

\title{
Privacy Preserving Dynamic Access Control Model with Access Delegation for eHealth
}

\author{
Faegheh Ghofrani \& Morteza Amini* \\ Department of Computer Engineering, Sharif University of Technology, Tehran, Iran
}

\begin{abstract}
eHealth is the concept of using the stored digital data to achieve clinical, educational, and administrative goals and meet the needs of patients, experts, and medical care providers. Expansion of the utilization of information technology and in particular, the Internet of Things (IoT) in eHealth, raises various challenges, where the most important one is security and access control. In this regard, different security requirements have been defined; such as the physician's access to the patient's EHR (electronic health record) based on the physician's physical location, detection of emergency conditions and dynamically granting access to the existing physician or nurse, preserving patients' privacy based on their preferences, and delegation of duties and related permissions. In security and access control models presented in the literature, we cannot find a model satisfying all these requirements altogether. To fill this gap, in this paper, we present a privacy preserving dynamic access control model with access delegation capability in eHealth (called TbDAC). The proposed model is able to tackle the security challenges of these environments when the physicians and nurses access the patients' EHR. The model also includes the data structures, procedures, and the mechanisms necessary for providing the access delegation capability.

The proposed access control model in this paper is in fact a family of models named TbDAC for access control in eHealth considering the usual hospital procedures. In the core model (called $\mathrm{TbDAC}_{0}$ ), two

* Corresponding author

* نويسندة عهدهدار مكاتبات


primitive concepts including team and role are employed for access control in hospitals. In this model, a set of permission-types is assigned to each role and a medical team (including a set of hospital staff with their roles) is assigned to each patient. In fact the role of a person in a team determines his/her permissions on the health information of the patient. Since patients' vital information is collected from some IoT sensors, a dynamic access control using a set of dynamic and context-aware access rules is considered in this model. Detecting emergency conditions and providing proper permissions for the nearest physicians and nurses (using location information) is a key feature in this model.

Since health information is one of the most sensitive individuals' personal information, the core model has been enhanced to be a privacy preserving access control model (named TbDAC $_{1}$. To this aim, the purpose of information usage and the privacy preferences of the patients are considered in the access control enforcement procedure.

Delegation of duties is a necessity in medical care. Thus, we added access delegation capability to the core model and proposed the third member of the model family, which is named TbDAC 2 . The complete model that considers all security requirements of these environments including emergency conditions, privacy, and delegation is the last member of this family, named $\mathrm{TbDAC}_{3}$. In each one of the presented models, the therapeutic process carried out in the hospitals, the relational model, and the entities used in the model are precisely and formally defined. Furthermore in each model, the access control process and the dynamic access rules for different situations are defined.

Evaluation of the proposed model is carried out using three approaches; comparing the model with the models proposed in related research, assessing the real-world scenarios in a case study, and designing and implementing a prototype of an access control system based on the proposed model for mobile Android devices. The evaluations show the considerable capabilities of the model in satisfying the security requirements in comparison to the existing models which proposed in related research and also its applicability in practice for different simple and complicated access scenarios.

Keywords: eHealth, IoT, Dynamic Access Control, Privacy, Access Delegation

$$
\begin{aligned}
& \text { در سالهاى اخير با كاربرد وسيع اينترت اشيا (IoT') } \\
& \text { در سلامت الكترونيكىى مواجه هستيهم وازٔه اينترنت اشيا } \\
& \text { نخستينبار توسط كوين اشتون [3] در سال } 999 \text { الدر زمينه } \\
& \text { مديريت زنجيرء تأمين مطرح، اما بهمرور تعاريف وسيعترى از }
\end{aligned}
$$

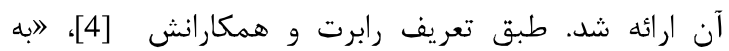

$$
\begin{aligned}
& \text { شبكةاى از تجهيزات دريافت داده مانند RFID، حس حرهاى } \\
& \text { مادون قرمز، سامانههاى موقعيتياب جهانى(GPS)، } \\
& \text { يويشرهاى ليزرى و ديخر ابزار سنجش اطلاعات كله بر مرون }
\end{aligned}
$$

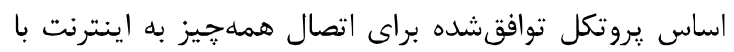

$$
\begin{aligned}
& \text { يكديخر ادغام مىشوند، اينترنت اشيا مى گوييهم. هدف از ارائٔ } \\
& \text { اين مجموعه رسيدن به مديريت و شناسايى آسان اين }
\end{aligned}
$$

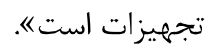

$$
\begin{aligned}
& \text { با كاربرد اينترنت اشيا در سلامت الكترونيكى، }
\end{aligned}
$$

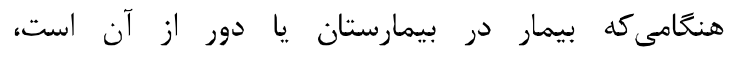

$$
\begin{aligned}
& \text { حسگرهاى متصل به بدن بيمار اطلاعات سلامت وى از بيدمان } \\
& \text { جمله ضربان قلب، فشار خون و تنفس را اندازهزيرى كرده و } \\
& \text { از طريق دستكاههايى همجون تلفن همراه به شبكه ارسال } \\
& \text { مى كنند [5]. اين اطلاعات بايد بهصورت امن به یايخاه داده }
\end{aligned}
$$

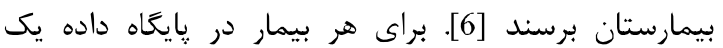

$$
\begin{aligned}
& \text { يرونده الكترونيكى سلامت (EHR) ايجاد مىشود كه طبق }
\end{aligned}
$$

${ }^{1}$ Internet of things

${ }^{2}$ Electronic Health Records

$$
\begin{aligned}
& \text { - - مقلد } \\
& \text { وازٔة سلامت الكترونيكى كه از سال ... . عموميت يافته. } \\
& \text { مفهوم جديدى است كد به استفاده از فناورى اطلاعات و } \\
& \text { ارتباطات در حيطهُ بهداشت اطلاق مىشود. طبق تعريف } \\
& \text { سازمان جهانى بهداشت [1]، سلامت الكترونيكى به معناى } \\
& \text { انتقال منابع سلامت و مراقبتهاى بهداشتى از طريق وسايل } \\
& \text { الكترونيكى و شامل سه حوزه اصلى است: ( () ارائه اطلاعات } \\
& \text { يزشكى به فرد متخصص از طريق اينترنت و ارتباطات راه دور } \\
& \text { (r) استفاده از فناورى اطلاعات و تجارت الكترونيكى براى } \\
& \text { (r) بهبود خدمات يزشكى از طريق آموزش افراد مرتبط ل) } \\
& \text { استفاده از تجارت الكترونيكى و كسبوكار الكترونيكى در }
\end{aligned}
$$

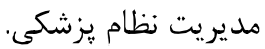

$$
\begin{aligned}
& \text { استفاده از سامانهاى الكترونيكى سلامت داراى } \\
& \text { مزيتهايى از جمله افزايش كيفيت سلامت و ايمنى بيماران، } \\
& \text { كاهش خطاى يزشكى، كاهش زمان دسترسى به اطلاعات } \\
& \text { مورد نظر و كاهش هزينه است؛ همجٍنين ثزشك مىتواند از } \\
& \text { تداخلها يا حساسيتهاى دارويى هنغام تجويز دارو [2] } \\
& \text { مطلع شود؛ بلعلاوه سامانههاى الكترونيكى سلامت، } \\
& \text { جمع آورى و به اشتراكگذارى دادههاى بالينى الكترونيكى } \\
& \text { بين سازمانهاى مختلف مراقبتهاى بهداشتى را بهسادگى } \\
& \text { امكانيذير مىسازند. }
\end{aligned}
$$


r- نيازمندىهاى سازمانى در كنترل دسترسى

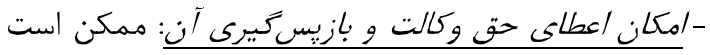

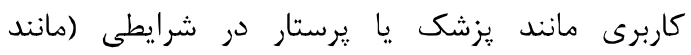

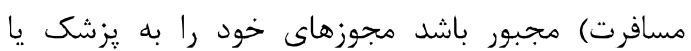

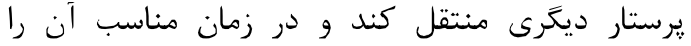
بازيس كيرد [12].

- دسترسى در موارد اضطرارى (اورزانس): مدل و سازوكار كنترل دسترسى بايد بهصورت بويا بهَّونهاى عمل كند

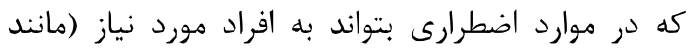

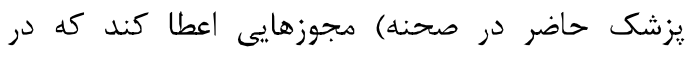
شرايط عادى، آن مجوزها را ندارند [13].

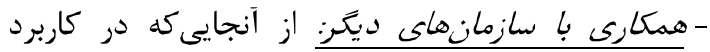

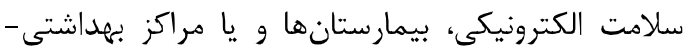
درمانى با سازمانهاى ديخر از جمله سازمانهاى بـان بيمها،

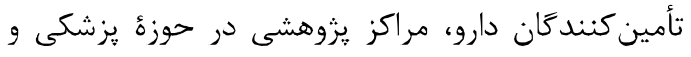

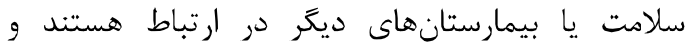

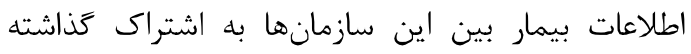

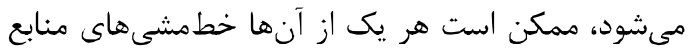

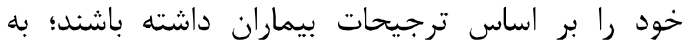

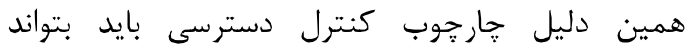
سازكارى بين اين خطمشىها را براى همكارى بهتر

فراهم كند [14].

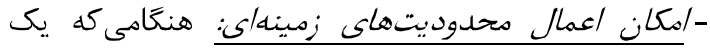
يزشك يا يرستار درخواست دسترسى به اطلاعات بيماران

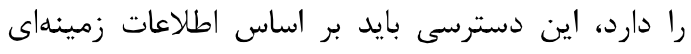
مانند زمان و مكان درخواست كننده، به شكل يويا قابل

كنترل باشد [15].

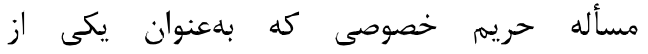
نيازمندى هاى مهم بيماران در كنترل دسترسى به آن آن اشاره

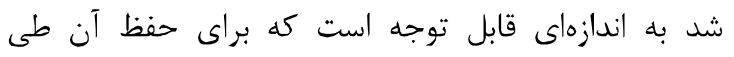

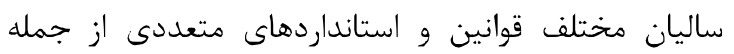
استاندارد HIPAA تدوين شده است. برخى از اصول اساسى كه براى سامانههاى حافظ حريم خصوصى بيان شده عبارتاند از: توان

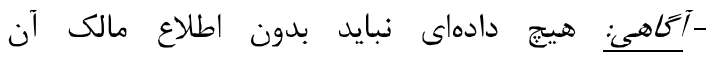

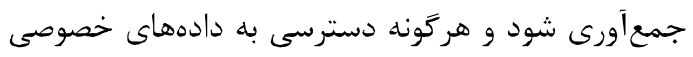
بايد به اطلاع آنها برسد.

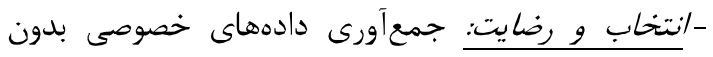

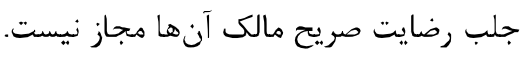

تعريف لاكويديس [7]، EHR عبارت است از لاطلاعات

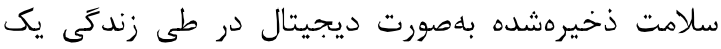

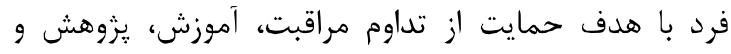

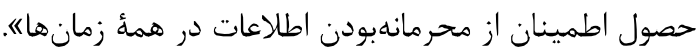

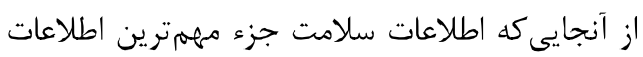

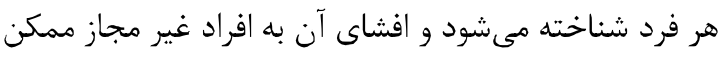

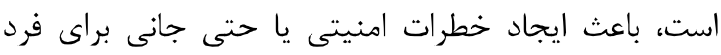

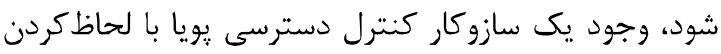
ملاحظات حريم خصوصى بيماران امرى ضرورى است.

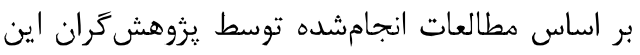

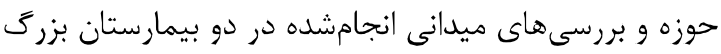

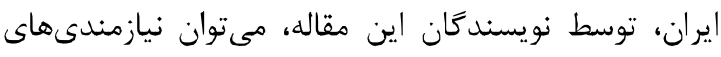

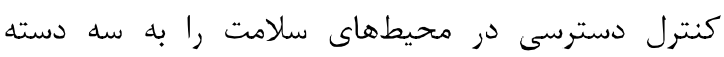

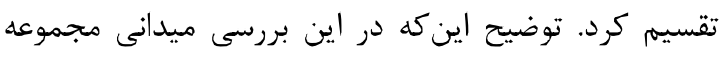

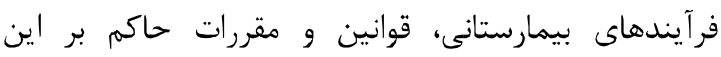
بيمارستانها (مطابق شيوهنامههاى ابلاغى وزارت بهداشت،

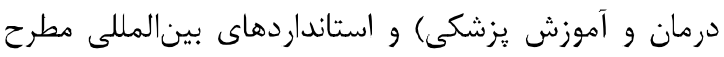

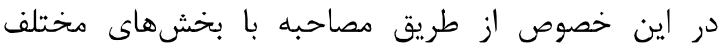
بيمارستانى استخراج و مورد بررسى و تحليل قرار كرفت إن. 1 - نيازمندى هاى عمومى كنترل دسترسى

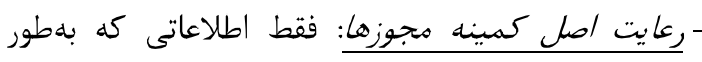

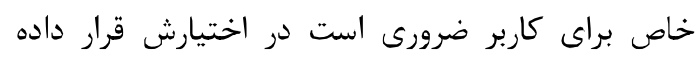
شود و ساير اطلاعات از ديد كاربر ينهان شود [8].

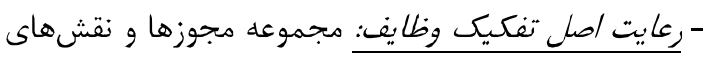
دادهده به يك فرد نبايد طورى باشد كه منجر به تضعيف خطمشىهاى مركز بهداشتى-درمانى شود يا بادي حريم خصوصى بيمار را به مخاطره بياندازد [9].

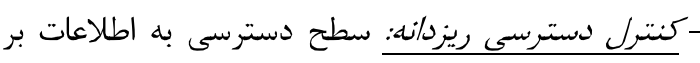
روى منابع بهصورت جزئى مشخص شود [10].

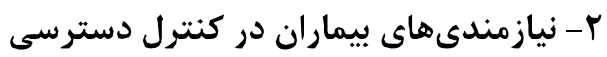

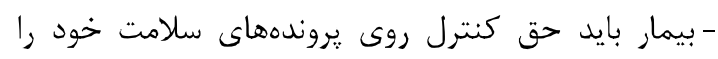

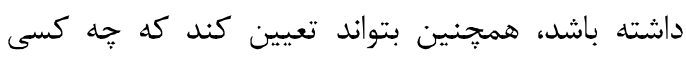
حق استفاده از اطلاعاتش را دارد [11].

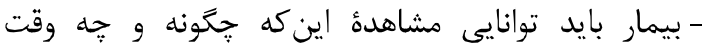

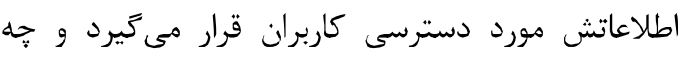

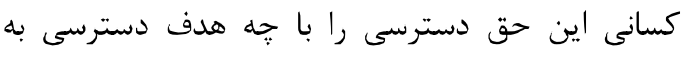
آنها مى دهند، داشته باشد [11] 
رفع نيازمندىهاى كنترل دسترسى در محيط سلامت

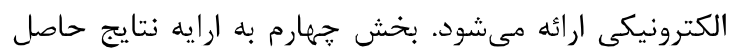

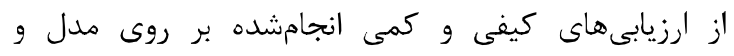

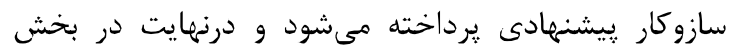

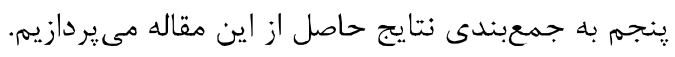

\section{r - كارهاى ييشين}

مدلها و سازوكارهاى مختلفى جهت كنترل دسترسى در محيطهاى سلامت الكترونيكى ارائه شده است كده هـ هر كدام

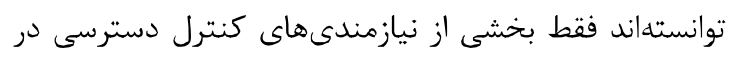

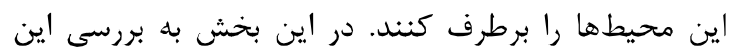
مدلها ير داخته شده است. ابتدا سه مدل كنترل دسترسى اختيارى، اجبارى و و

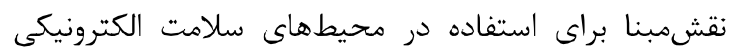

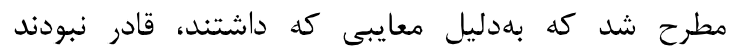

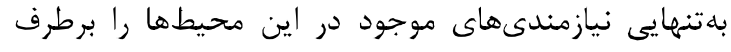

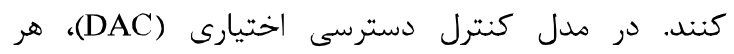
كاربرى كه مسئول جمع آورى اطلاعات است، مالك اطلاعات يا منابع موردنظر مىشود؛ درصورتى كه در كاربرد سلامت

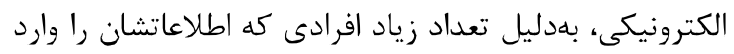
مى كنند، هيج كس نمىتواند ادعا كند كه مالك اين اطلاعات

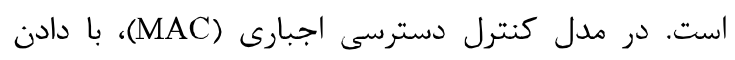

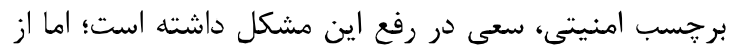

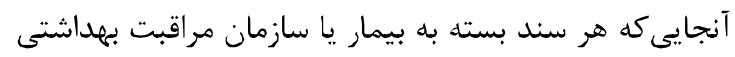

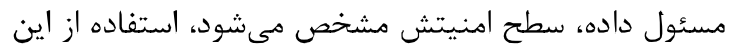

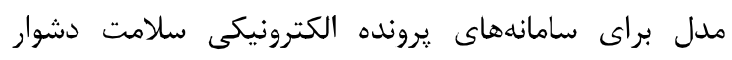

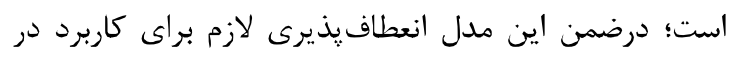

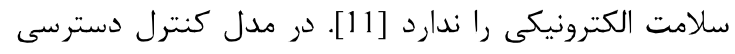

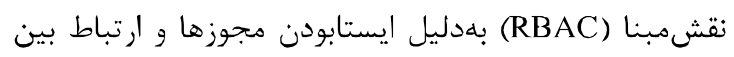

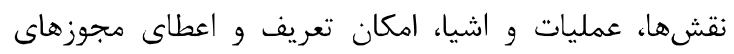
يويا را (كه در كاربرد سلامت الكترونيكى به آنهات آنها بسيار نيازمنديم) ندارد. مدل كندر (ABAC)

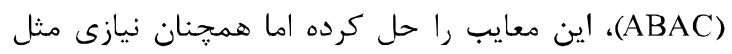

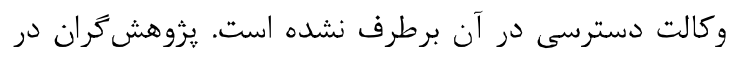

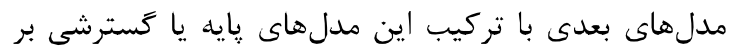
مدل نقشمبنا سعى كردند يكى مدل كنترل دسترسى ارئ مدائه

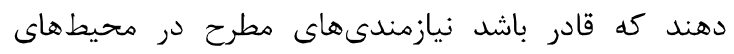
سلامت الكترونيكى را برطرف سازد.
-مجاورت و محلىيودن: دادها و اطلاعات از مرزهاى فيزيكى يك مكان مورد اعتماد خارج نشوند. -الزامات /منيتى: حفاظت از حريم خصوصى مستلزم ايجاد يك بستر امن براى دادههاى خصوصى است، مانند إنداني رمزكذارى دادها.

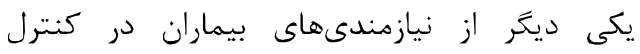

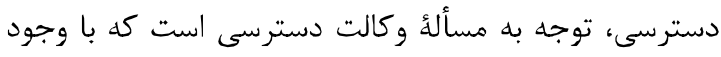

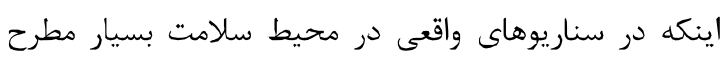
است، اما در محيط يزوهشى كمتر به آن توجه شده است.

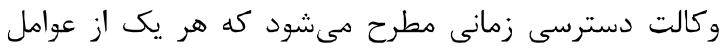

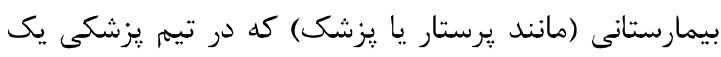

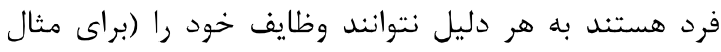

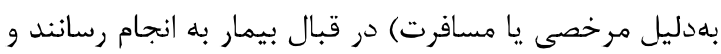

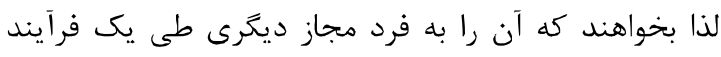

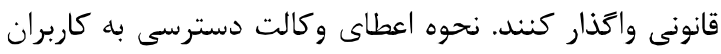

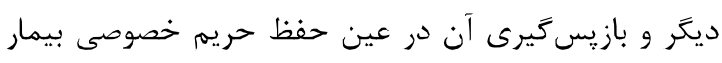

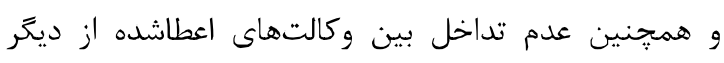
جزيياتى است كه در وكالت دسترسى لازم است، مدنظر قرار كيرند. در سالهاى اخير مدلها و سازوكارهاى كنترل دسترسى مختلفى با هدف رفع اين نيازمندى احها ارائه شده

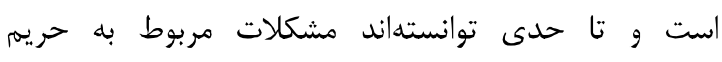

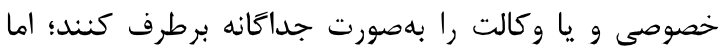

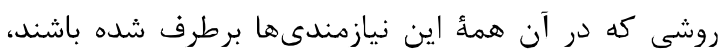

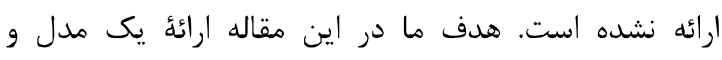

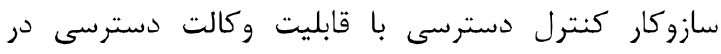

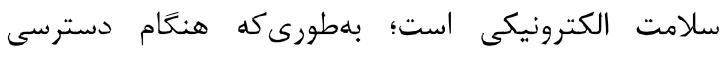

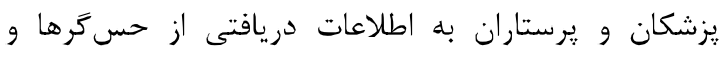

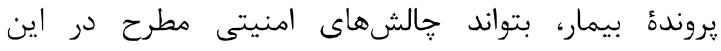

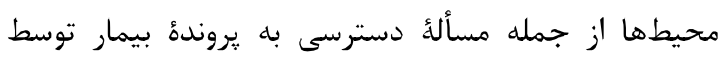

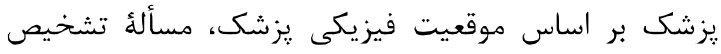

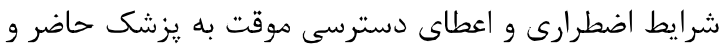

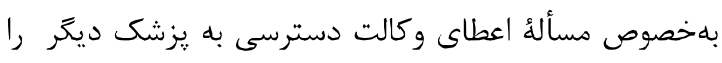

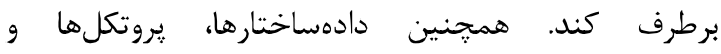
سازوكارهاى لازم را براى برخوردارى از قابليت وكالت دسترسى نيز داشته باشد.

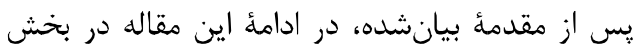

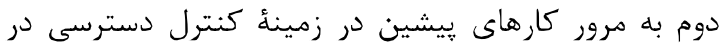

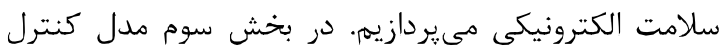

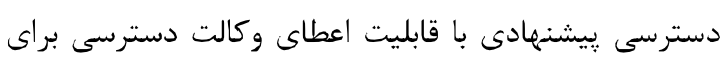


خصوصى از آنها استفاده مىشود. در مدلى ديكر يانى ها هو

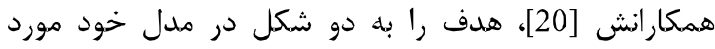
استفاده قرار دادند. هدف مالك داده و هدف هدف دسترسى كه

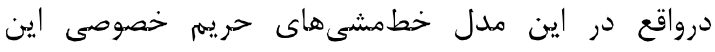

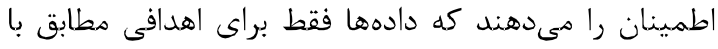
اهداف تعيينشده توسط مالك داده مورد دسترسى قرار ادهار

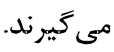

سيكورانزا9 و همكارش [11]، با استفاده از مدل

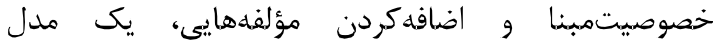

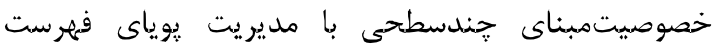
كاربران ارائه داده است. هدف مدل ارايهشده در اين مقاله،

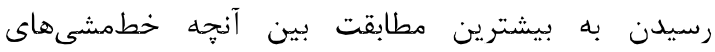
دسترسى به ما اجازه مي دهند تا تعريف كنيهم و آنجه بيماران

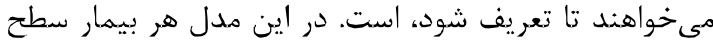

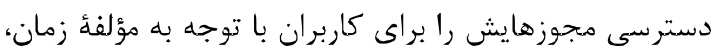
شرايط و اهداف دسترسى آن كارير تعيين مى كند. اين اين آندان

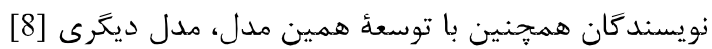

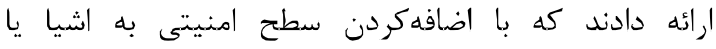

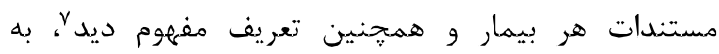
بيماران اجازه مىدهد كه براى هر كاربر يك دئ ديد تعريف

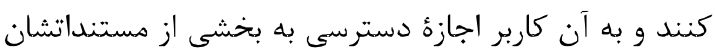

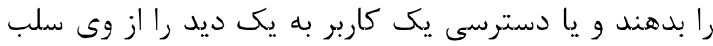

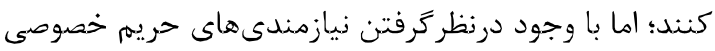

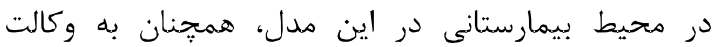
دسترسى و كنترل دسترسى در شرايط اضطرارى در اين

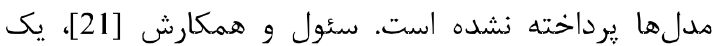
هدل كنترل دسترسى مبتنى بر ابر براى ركوردهاى سلاهت

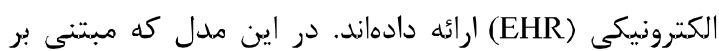
ويزگى است، براى حفظ حريم خصوصى از روشهاى رمزنگارى و امضاى ديجيتال XML استفاده شده، اما در اين روش به مسأله وكالت دسترسى يرداخته نشده است. عبدالمجيد [22]، يك مدل كمنامسازى جديد براى حفظ حريم خصوصى دادههاى بروندههاى سلامت الكترونيكى ارائه

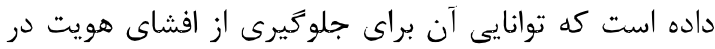

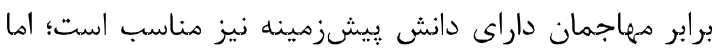

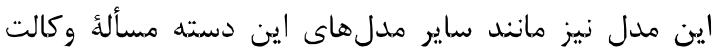

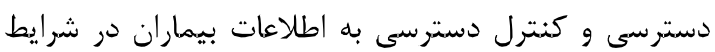

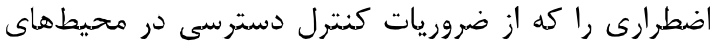

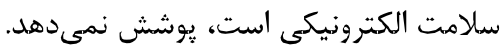

${ }^{5}$ Yang

${ }^{6}$ Sicuranza

${ }^{7}$ View
I- - - مدلهاى كنترل دسترسى آكاه از زمينه جرجيديس' و همكارانش [16]، از تركيب مدل RBAC و

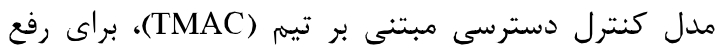
نيازمندىهاى زمينهاى استفاده كردند. مؤلفئ تيم هماندا تئد

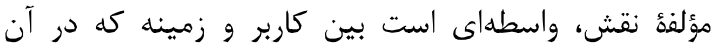
كاربران و نقشها مي توانند در يك نشست، به به عنصر تيهم

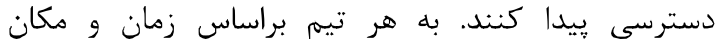

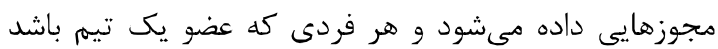
مىتواند به مجوزهاى همان تيم دسترسى وييدا كند. در اين

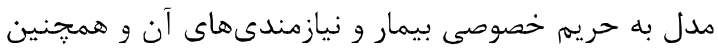
كنترل دسترسى به اطلاعات بيماران در شرايط اضطرارى و و ندارئ وكالت دسترسى يرداخته نشده است.

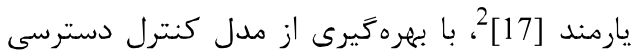

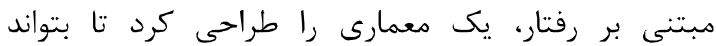

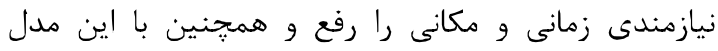

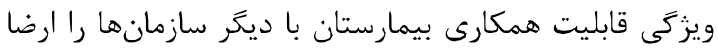

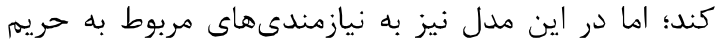
خصوصى و وكالت دسترسى توجه نشده است. جورجيكاكيس [18]3، با كسترش دادن مدلى با عندان STEM-RBAC توانست سه نيازمندى محدوديت مكاني،

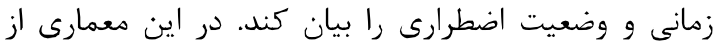
مؤلفههايى مانند مؤلفهُ نظارت بر موارد اضطرارى و مؤلفئه نظارت امنيت استفاده شده و براى هر يك از اين مؤلفهها الكوريته تصميمكيرى بهصورت صورى بيان شده است. در

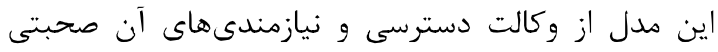
نشده است.

\section{r-Y - مدلهاى مرتبط با نيازمندىها و حريم \\ خصوصى بيمار}

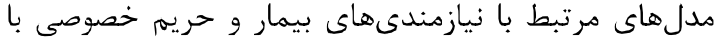

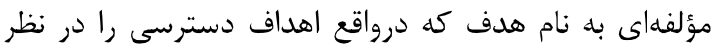

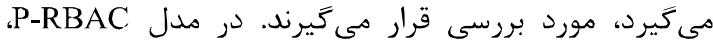

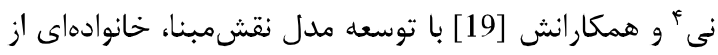
مدلهاى آكاه به حريم خصوصى ارائه دادند تا بتوانند بلهطور

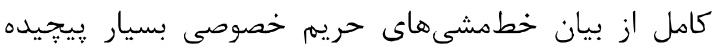

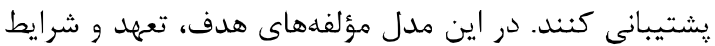
اضافه شده است كه براى تعريف مجوزهاى حافظ حريم

\footnotetext{
' Georgiadis

${ }^{2}$ Yarmand

${ }^{3}$ Georgakakis

${ }^{4} \mathrm{Ni}$
} 
هنگامى كه بيمار در شرايط اضطرارى است، برطرف كند و

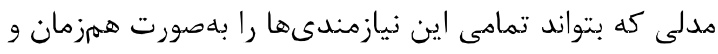

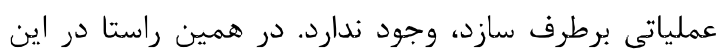

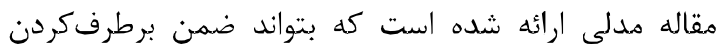

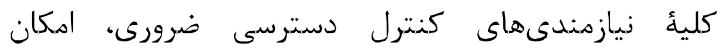

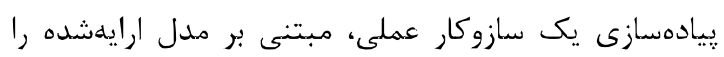

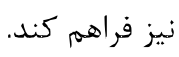

\section{r- مدل كنترل دسترسى ييشنهيادى}

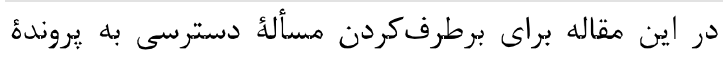
بيمار توسط يزشك براساس موقعيت فيزيكى بز بركى، مسأله

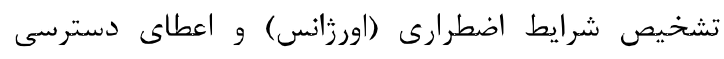

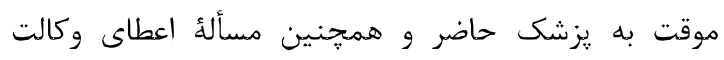

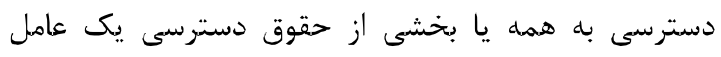

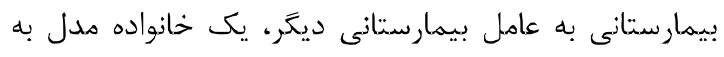

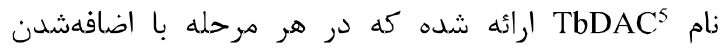

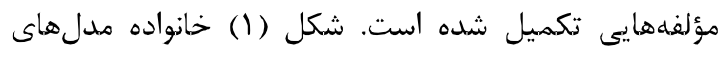

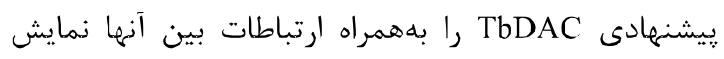

در هر كدام از مدل هاى ارائهشده ابتدا فرآيند درمانى

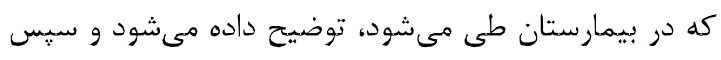

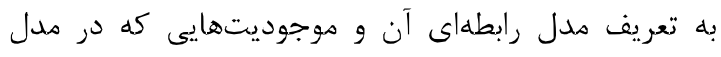

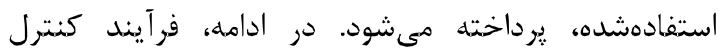

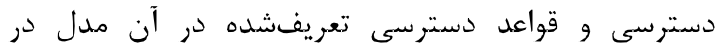

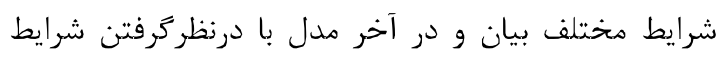

اضطرارى تكميل مىشود.

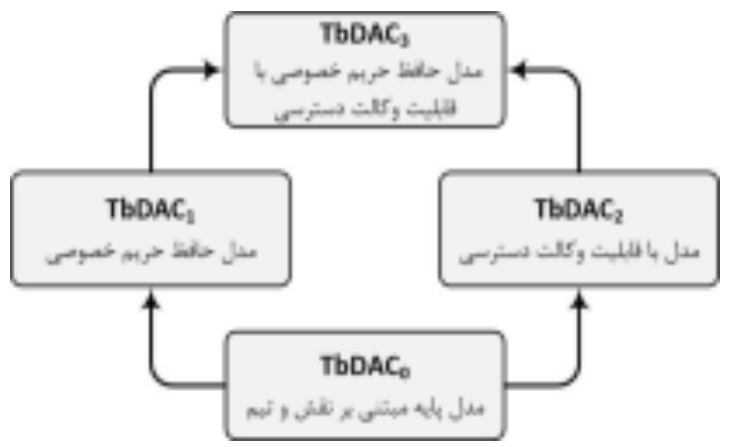

(شكل - (): خانواده مدل هاى كنترل دسترسى بيشنهرادى TbDAC

(Figure-1): Proposed TbD $\Lambda C$ access control model family

${ }^{5}$ Team-based Delegation Access Control r-r - مدل هاى مرتبط با سلامت الكترونيكى

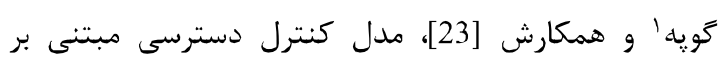

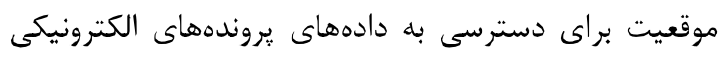

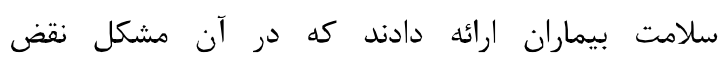

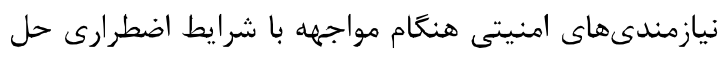

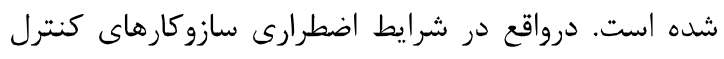

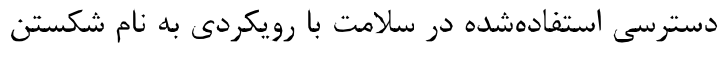

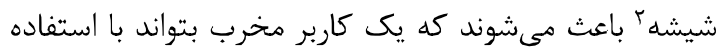

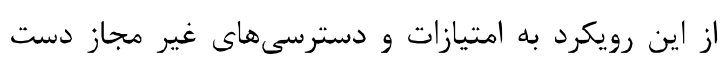

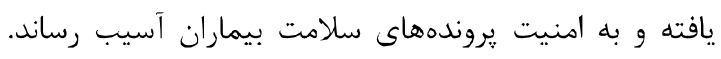

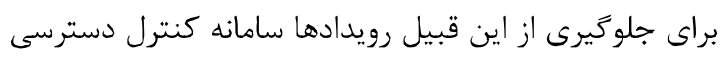

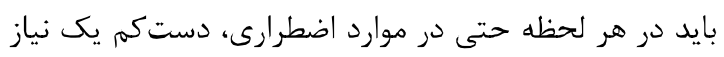

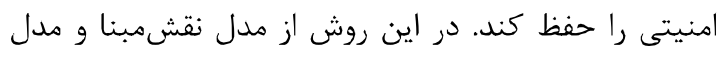

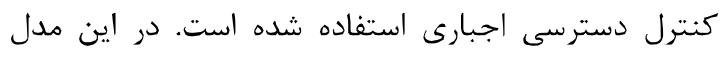

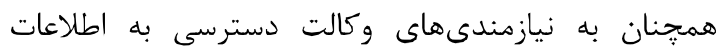

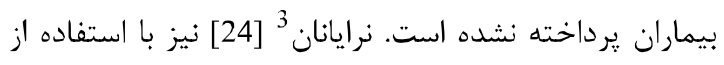
مدل كنترل دسترسى مبتنى بر وظايف (TBAC) به ارضاى بردي

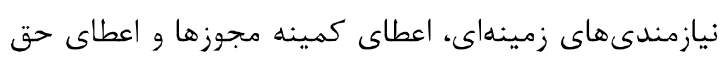

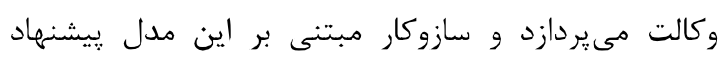

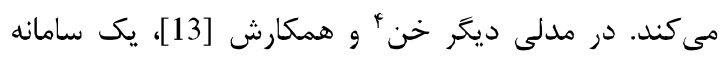

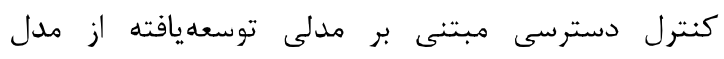
نقشمبناى RBAC براى كاربرد سلامت الكترونيكى ارائه دادند كه در آن شرايط اضطرارى بلهعنوان زمينه و خصوصيت

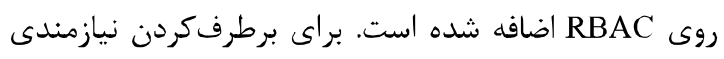

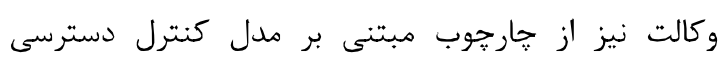

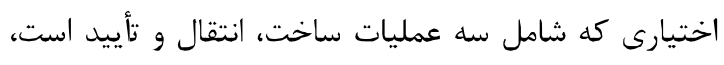

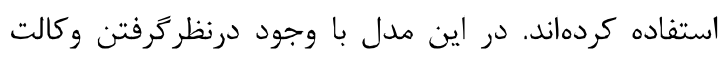

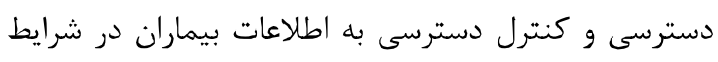

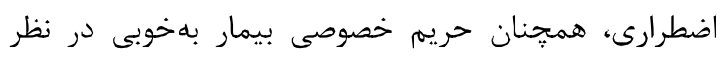
كرفته نشده است.

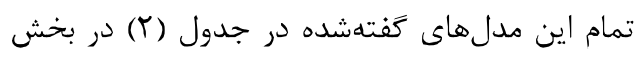

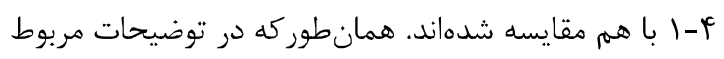

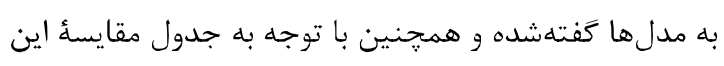

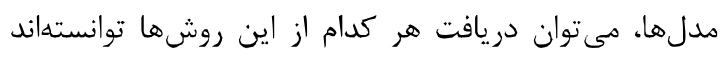

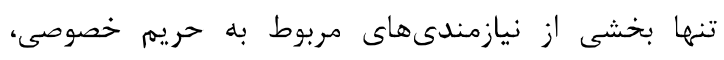

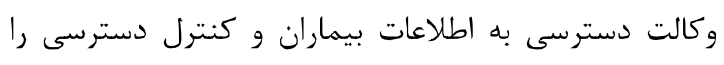

1 Gope

${ }^{2}$ Break the glass

${ }^{3}$ Narayanan

${ }^{4}$ Khan 
از زمان ورود تا آن لحظه شامل آزمايشها و تجويزها به

ו- T- مدل هستة

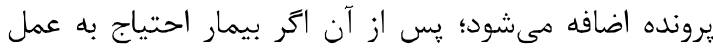

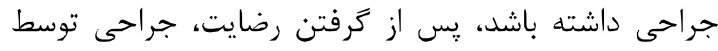
يزشك انجام مىشود؛ اگر نياز به عمل نيز وجود نداشته باشد، بيمار به بخش مربوطه منتقل شده و در آنجا بسترى مىشود.

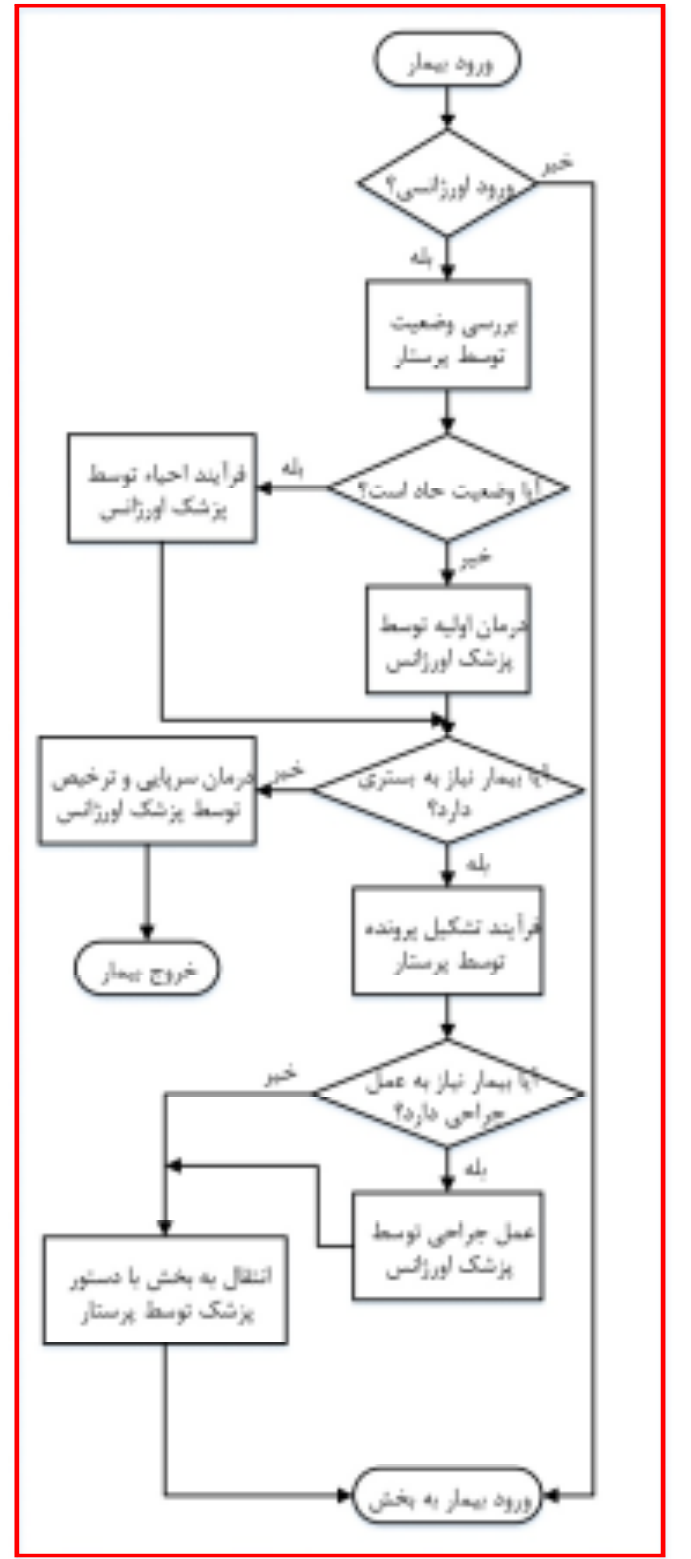

(شكل-r): روند ورود و درمان بيماران در اورزانس

(Figure-2): Patient entrance and treatment process in hospital Emergency room

فرآيند انتقال بيمار از اورزانس به بخش (شكل ب) نيز بهاينترتيب است كه يزشك اورزانس دستور انتقال را صادر و يرستار مسئول شيفت با بررسى :برونده و هماهنكى با واحد
مدل هسته شامل مدلى ساده براى كنترل دسترسى در

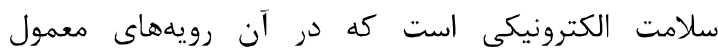

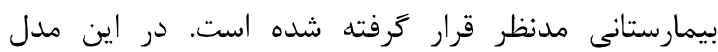

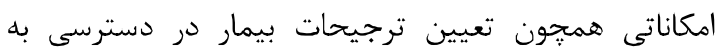

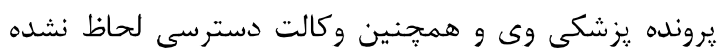

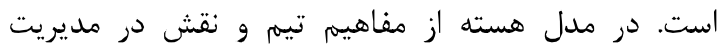
دسترسىها بهره گرفته شده است.

$$
\text { |-1- - - فر آيندهاى درمانى }
$$

با توجه به تأثير فرآيندهاى درهانى در تبيدين فرآيندهاى مديريت كنترل دسترسى لازم است ابتدا اين فرآيندها تشريح شوند.

فرآيندهاى درمانى با ورود بيماران به بيمارستان آغاز

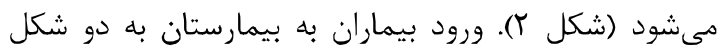

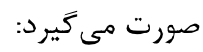
- بيمارانى كه از قبل به درمانكاه مراجعه كرده و با با. هماهنتَى يزشك بيمارستان و بان دريافت درخواست

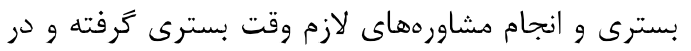
روز تعيينشده به يذيرش مراجعه و تشكيل يرونده

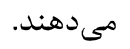

- بيماران اورزانسى كه بهصورت اضطرارى وارد بخش اورزانس شده و بهطورموقت در اين بخش بسترى و بعد از

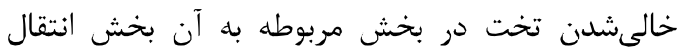

$$
\text { داده مىشوند. }
$$

بيمارانى كه از طريق اورثانس وارد بيمارستان مىشوند ابتدا توسط سريرستار در يكى از تختهاى خالى ترى

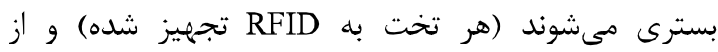
آنجايى كه هر :رستار مسئول رسيدگى به به بيماران مجموعهاى از تختهاى مشخص است، يس از بسترىشدن بيمار، يرستار

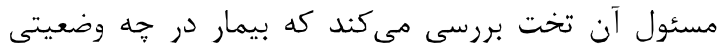

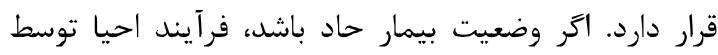
يزشك اورزانس براى او انجام، در غير اين صورت يس از

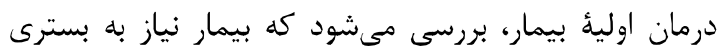

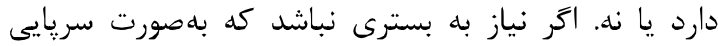

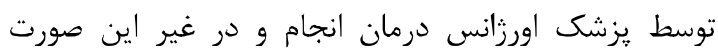

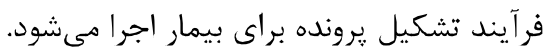
در فرآيند تشكيل يرونده كافى است يرونده سلامت بيمار كه از قبل وجود دارد، بلروز شود؛ يعنى روند درمان او 


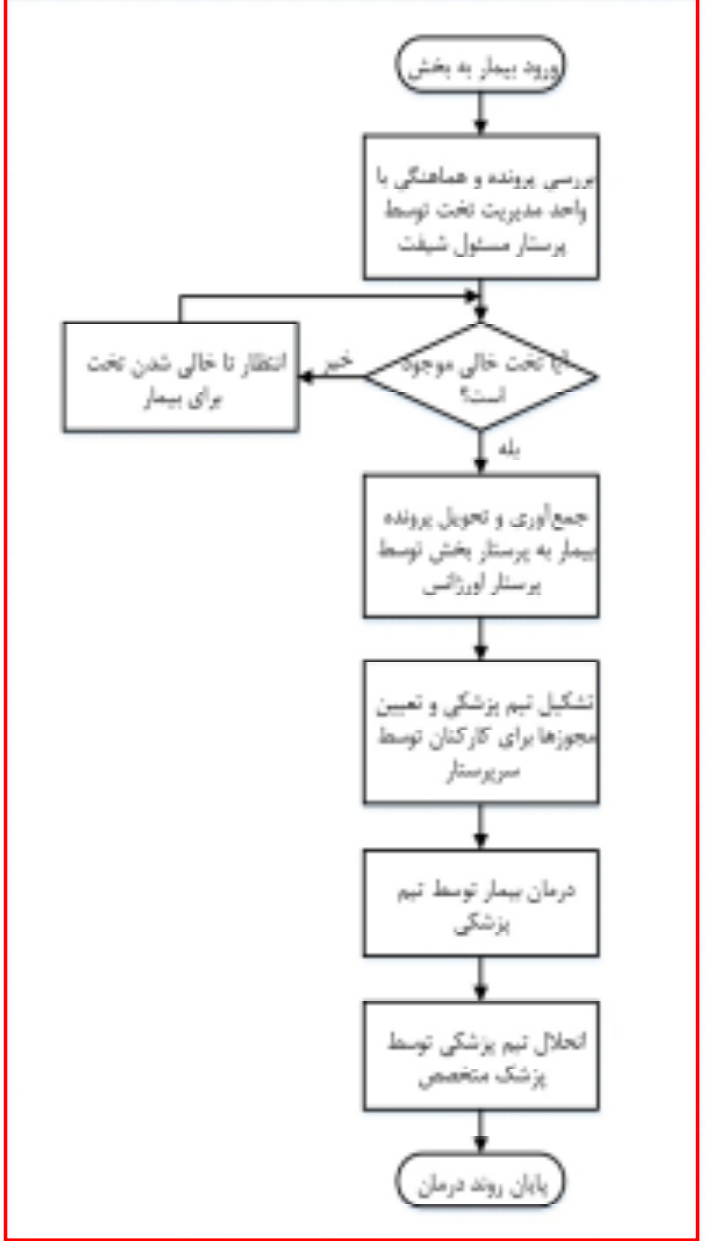

(شكل - Y): فر آيند درمان بيمار در بخشهاى بيمارستانى

(Figure-3): Patient treatment process in hospital departments

TbDAC

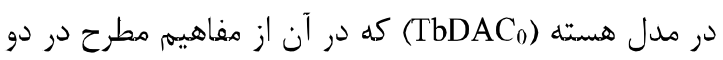

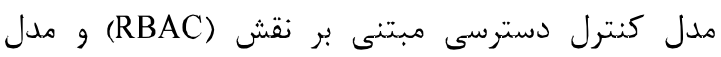

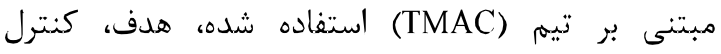
دسترسى در محيط بيمارستان با توجه به الكترونيكى شدن يروندة بيماران است. در اين مدل، كه در شكل (4) نشان

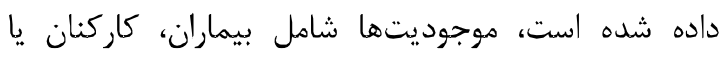

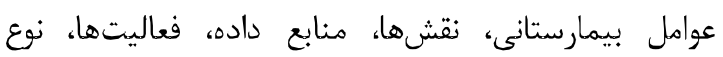

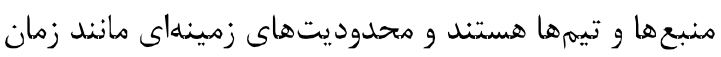

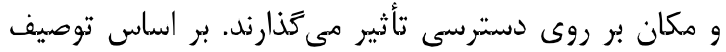
كلى ارائهشده از شرايط حاكم در هحيط بيمارستان و و

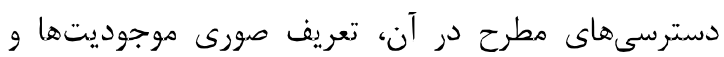
روابط بين آنها در مدل كنترل دسترسى ارايهشده، در ادامه دهري

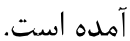

مديريت تخت جهت گرفتن تخت خالى براى انتقال بيمار

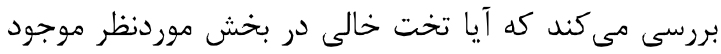

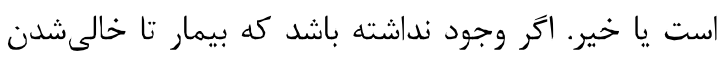
تخت در اورزانس مىماند؛ اما اگر تخت خالى وجود داشت، يرستار هرونده بيمار را همراه بيمار به رزيدنت يا برستار

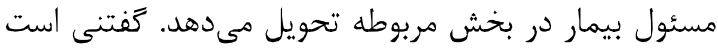
تمامى اين فرآيندها تحت نظارت و دستور سريرستار انجام مى كيرد.

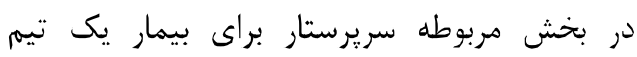

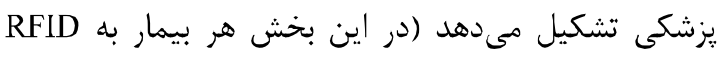
مجهز شده است) و مجوزهاى لازم را براى هركدام از افراد

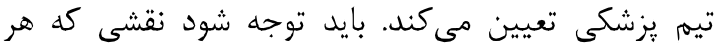

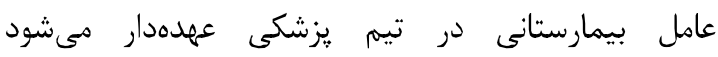
زيرمجموعهاى از نقشهاى مجاز او باشد.

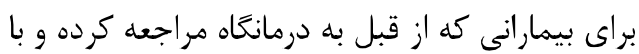
هماهنكى با يزشك خود وقت بسترى مى گيرند، در روز

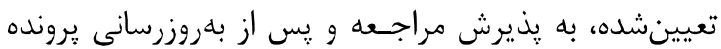

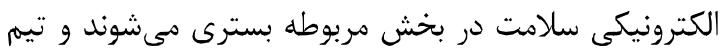
يزشكى براى آنها تشكيل مىشود.

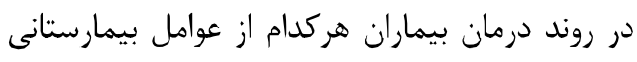

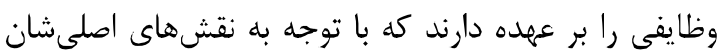

$$
\text { عهدهدار اين وظايف مىشوند. }
$$
- سريرستار وظيفه دارد ترجيحات خصوصى بيماران را ثبت

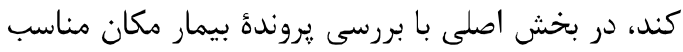

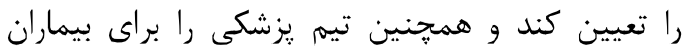

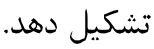
- يزشك اورزانس وظيفه درمان اولية بيمار، عمل جراحى داري

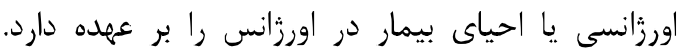
همجنين دستور انتقال بيمار از اورزانس به بخش مربوطه

$$
\text { توسط يزشك اورزانس صورت مى }
$$

يزشك بخش (متخصص) وظيفه درمان بيمار در تيم

$$
\text { يزشكى و انحلال تيم را برعهده دارد. }
$$

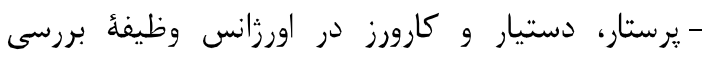
وضعيت اولئٔ بيمار را برعهده دارند. قبل از تحويل بيمار به سريرستار در بخش اصلى، يرونده بيمار را بهروزرسانى مى كنند. همجنين در بخش اصلى با توجه به تيم يزشكى كه در آن عضو هستند، به اطلاعات بيمار دسترسى دارند. 


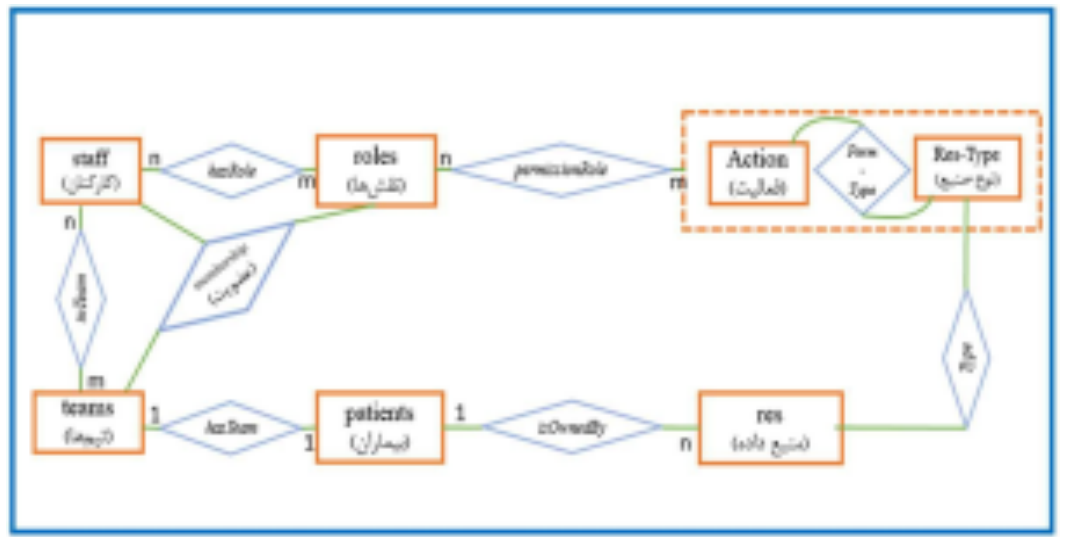

(شكل -F): مدل دادهاى كنترل دسترسى يايه در سلامت الكترونيكى

(Figure-4): Basic access control data model for e-health

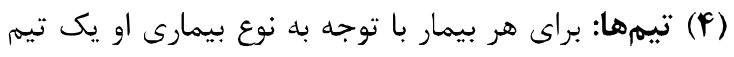

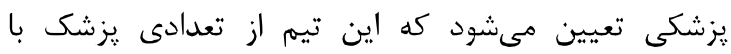
تخصصهاى مختلف، يرستار و كارورز تشكيل شده است.

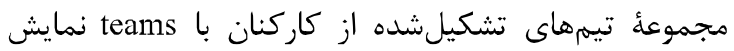

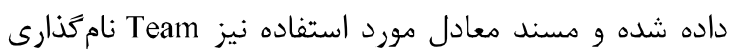
شده است. - است

(ه) منبع داده: يروندة هر بيمار از دادههاى مختلفى تشكيل

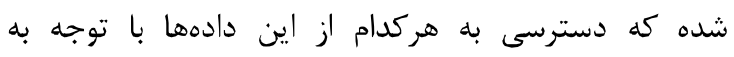

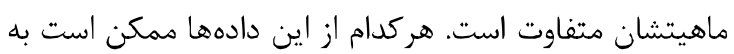

$$
\text { سه صورت دستهبندى شود: }
$$

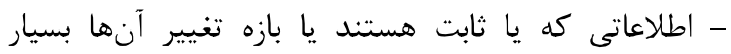

$$
\text { طولانى است مانند نام يا سن بيمار. }
$$

- اطلاعاتى كه در بازه كوتاهترى تغيير مى كنند. اطلاعات

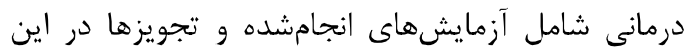

$$
\text { دسته جاى مى زيرند. }
$$

- اطلاعاتى كه در بازء كوتاهى از زمان تغيير مئن كند و شامل

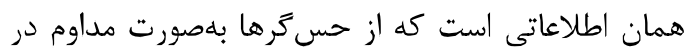

$$
\text { حال اندازهخيرى است. }
$$

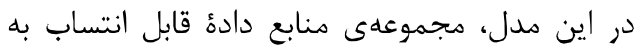

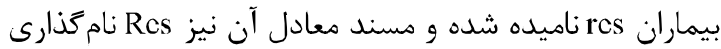

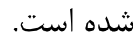

(థ) نوعنبع: هركدام از منابع داده داراى نوعى است كه اين

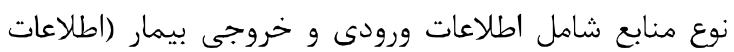
هويتى، اطلاعات حسگرها و اطلاعات بيمه درمانى)، اطلاعات

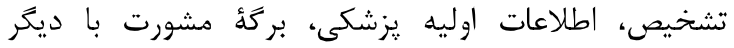

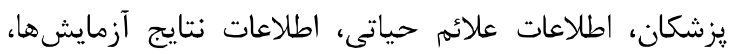

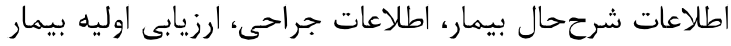

(1) بيماران: كاربرانى هستند كه وارد بيمارستان شده و از

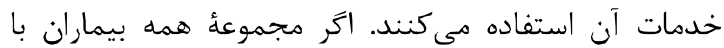
نمايش داده شوند و مسند معادل مورد استفاده

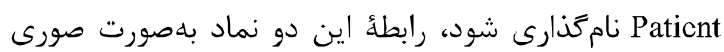

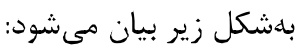

- $\quad$ Patient(x) = True $\leftrightarrow x \in$ patients (ץ) كاركنان (عوامل بيمارستانى): كاربرانى هستند كه در

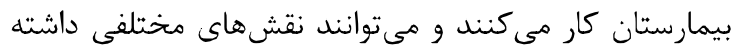

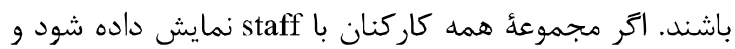
مسند معادل مورد استفاده Staff نامگذارى شود، رابطئ اين دو نماد بلهورت صورى بهشكل زير بيان مىشود: - $\operatorname{Staff}(x)=$ True $\leftrightarrow x \in \operatorname{staff}$ (Y) نقشها: نقشهايى كه در بيمارستان وجود دارد و به كاركنان منتسب مىشود. بلطوركلى مىتوان نقشها را در

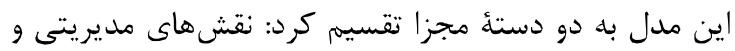

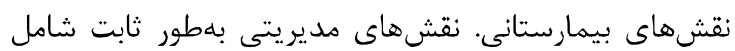
دو نقشِ مدير ارشد امنيتى (SU) و مدير امنيتى بخش (DSO)

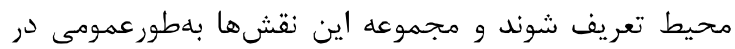

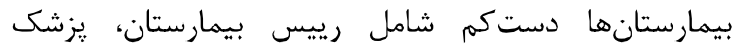

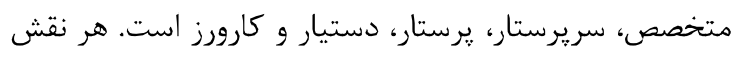
با انتساب به مجموعداى از نوعمجوزها تعريف مىشود. بايد در

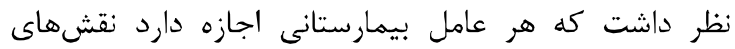
خاصى را با توجه به مدارى و كواهى هاى مورد تأييد وزارت بهداشت، درمان و آموزش يزشكى (مانند يزشكى يا يرستارى) عهدهدار شود. در اين مدل، مجموعء نقشهاي قابل انتساب

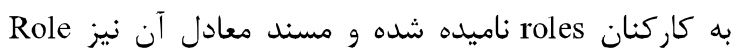
نامخذارى شده است. 
سريرستار) يك تيم بزشكى اختصاص داده مىشود. تابع

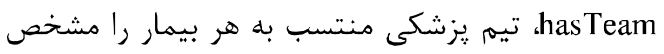

مى منمايد.

hasTeam: patients $\rightarrow$ teams

HasTeam $(\mathrm{p}, \mathrm{tm})=$ True $\leftrightarrow$ hasTeam $(\mathrm{p})=\operatorname{tm} \quad(r)$

$$
\text { . هر منبع داده، متعلق به يك بيمار است. }
$$

isOwnedBy: res $\rightarrow$ patients

IsOwnedBy $(d, p)=$ True $\leftrightarrow(d, p) \in$

isOwnedBy

رابطة permissionRole يك رابطة هندبه هند است كه

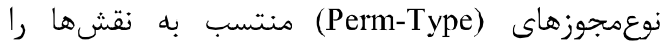

مشخص مى كند. توجه كنيد كه مفهوم نوعمجوز با مفهوم مجوز كه در مدلهاى نقشمبنا تعريف شده،

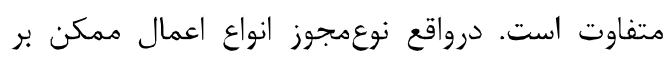
روى انواع منابع (يا انواع اشيا) را توصيف مى كند؛ در صورتى كه مجوز، مجازبودن عمل بر روى خود منابع (اشيا) ر ا مشخص مى كند. در اين مدل درواقع نوعمجوزها (و نه خود مجوزها) به نقشها منتسب مىشوند؛ سيس بر اساس نوعمجوزها و تيمى كه فرد در ان عضويت دارد، مجوزهاى روى منابع استنتاج

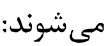

PermissionRole $\subseteq$ Perm-Type $\times$ roles assignedPermission : roles $\rightarrow 2^{\text {Perm-Types }}$ assignedPermission $(\mathrm{r})=$

$\{p t \in$ Perm-Type $\mid(p t, r) \in$ PermissionRole $\}$

AssignedPermission $(r, a, t)=$ True

$\leftrightarrow \quad(\mathrm{a}, \mathrm{t}) \in$ assignedPermission(r)

9. رابطة بين هر نوعنبع با منابع داده يك رابطه يك به جند است. يعنى هر منبع داده به يك نوع-منبع منتسب مىشود و هر نوع-منبع شامل جندين منبع داده است.

type: res $\rightarrow$ res-Type

$\operatorname{Typc}(\mathrm{d}, \mathrm{t})=\operatorname{Truc} \leftrightarrow \operatorname{typc}(\mathrm{d})=\mathrm{t}$

Vembership مابك رابطه بين سه مؤلفهُ كاركنان، تيمها و نقشها است كه مشخص مى كند هر عامل بيمارستانى در هر تيم با جه نقشى عضويت دارد: membership $\subseteq$ staff $\times$ team $\times$ roles membership $(\mathrm{s}, \mathrm{tm}, \mathrm{r}) \rightarrow \operatorname{HasRole}(\mathrm{s}, \mathrm{r}) \wedge$ $\operatorname{InTeam}(\mathrm{s}, \mathrm{tm})$

$\operatorname{Mcmbership}(\mathrm{s}, \mathrm{tm}, \mathbf{r})=$ Truc $\leftrightarrow$

$(\mathrm{s}, \mathrm{tm}, \mathrm{r}) \in$ membership
(اطلاعات خاص در زمان نخستين بازديد)، گزارش پرستار و

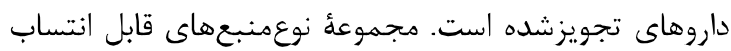
به منابع دادهاى با res-type مشخص شده و مسند معادل آن نيز Res-typc نام كذارى شده است.

فعاليتها: اعمالى هستند كه بر روى نوع منبعها (V) مىتوانند اجرا شوند؛ مانند خواندن و نوشتن. در اين مدل

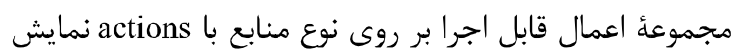
داده شده و مسند معادل ان Action ناميده شده است استر نوع مجوز: هر نوعجوز بهصورت مجموعهاى از اعمال (1) بر روى نوع منابع تعريف مىشود؛ لذا مجموعه كل

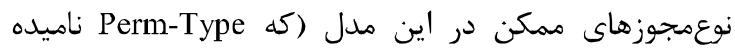
شده) بهصورت زير تعريف مىشود. توجه كنيد كه مجموعه توانى X ل استى:

- $\quad$ Perm-Type $=2^{\text {(actions×res-Type) }}$

علاوهبر مفاهيم يا موجوديتهاى بالا، روابطى در اين مدل تعريف شده است كه ارتباط بين موجوديتهاى مدل با موائ يكديگر را بيان مى كند. اين روابط در ادامه تعريف و به شكل صورى توصيف شدهاند. I. رابطهُ بين كاركنان و نقشها يك رابطهُ جند به است. يعنى هر يك از كاركنان ممكن است، نقشهاى مختلفى داشته باشند و هر نقشى به كاركنان مختلف منتسب شود. اين رابطه hasRole ناميده مىشود. تابع assignedRole

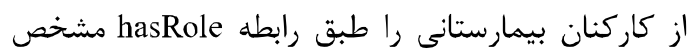
مى كند:

hasRole $\subseteq$ staff $\times$ roles

HasRolc $(\mathrm{s}, \mathrm{r})=$ True $\leftrightarrow(\mathrm{s}, \mathrm{r}) \in$ hasRole assignedRole : staff $\rightarrow 2^{\text {roles }}$ assignedRole $(s)=\{r \in \operatorname{roles} \mid(s, r) \in$ hasRole $\}$

r. رابطة بين تيمهاى يزشكى و كاركنان (با نام inTeam)

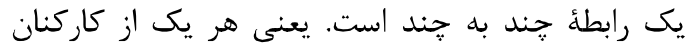
ممكن است، عضو جند تيمم ״زشكى باشند و هر تيم

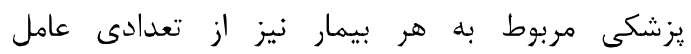
بيمارستانى تشكيل شده باشد.

inTeam $\subseteq$ staff $\times$ teams

$\operatorname{InTeam}(\mathrm{s}, \mathrm{tm})=$ True $\leftrightarrow(\mathrm{s}, \mathrm{tm}) \in$ inTeam

assignedTeam : staff $\rightarrow 2^{\text {teams }}$

assignedTeam $(\mathrm{s})=\{\mathrm{tm} \in$ teams $\mid(\mathrm{s}, \mathrm{tm}) \in$ inTeam\}

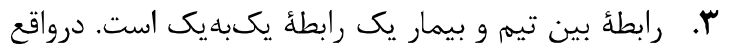
به هر بيمار (با توجه به حضور در بخش و تشخيص ربه ربه 
9 isMemberOfTeam(s) $=\{p \in$ patients $(\mathrm{s}, \operatorname{hasTeam}(\mathrm{p})) \in$ inTeam $\}$

IsMemberOfTeam $(s, p)=$ True $\leftrightarrow(\mathrm{s}, \mathrm{p}) \in$ isMemberOfTeam
A. تابع isMemberOfTeam بيمارانى را كه يك عامل بيمارستانى در تيم يزشكى آنها قرار دارد، مشخص

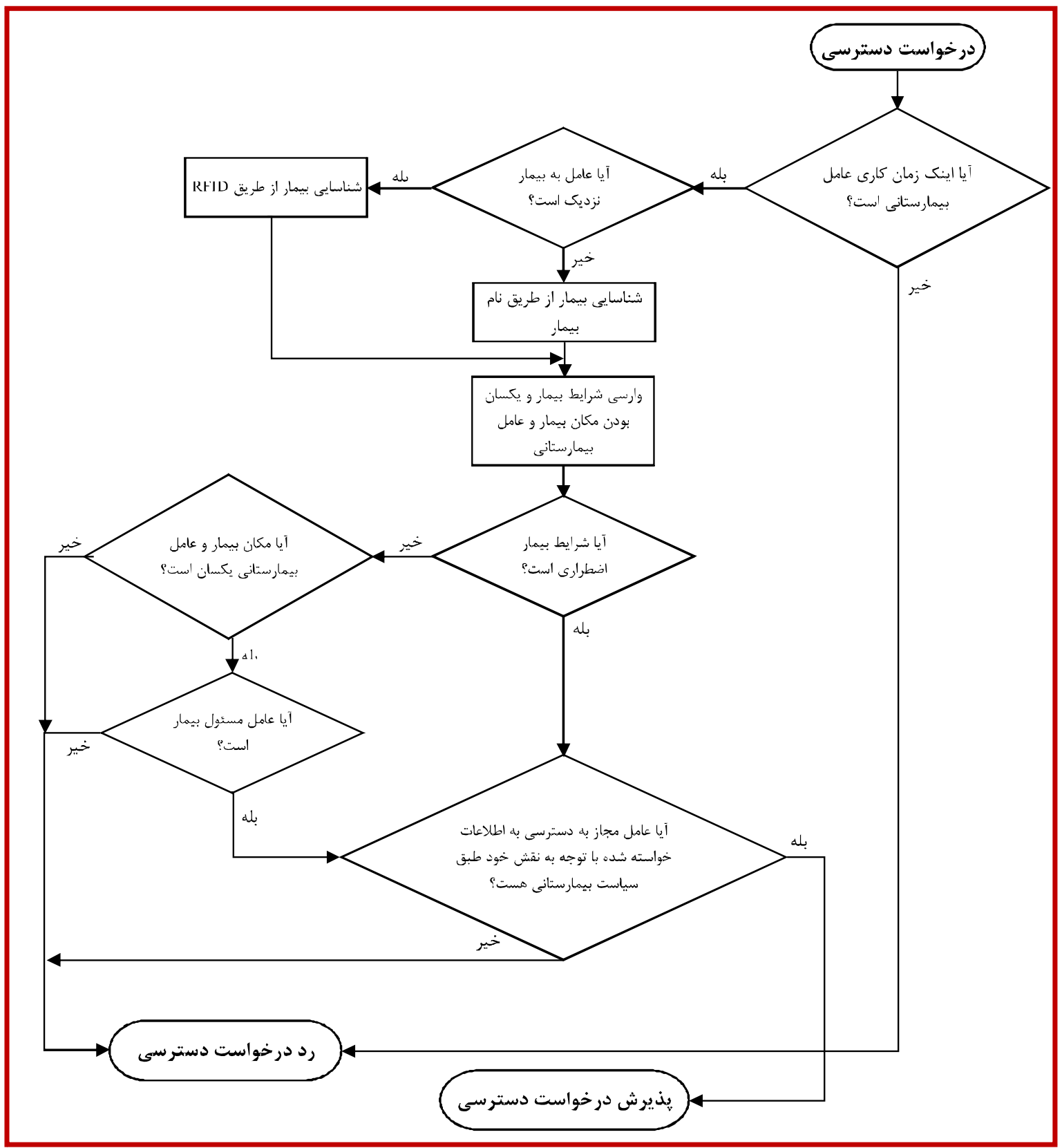

(شكل - (ه): فر آيند كنترل دسترسى

(Figure-5): Access control process

بررسى مىشود كه اينك زمان كارى عامل بيمارستانى هست يا نه؟ در صورت مثبتبودن نتيجه، بررسى مىشود اين عامل

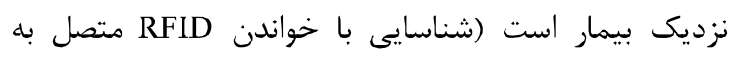

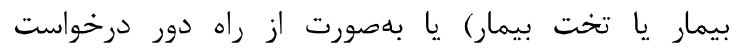

r-1-r - فر آيند كنترل دسترسى در اين مدل فرض بر اين است كه بيمار در بيمارستان

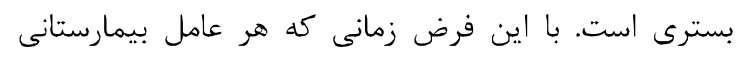
درخواست دسترسى به اطلاعات بيمار را داشته باشد، ابتدا 


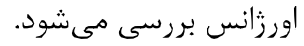

اكر طبق قواعد كنترل دسترسى تعريفشده در زورايخاه

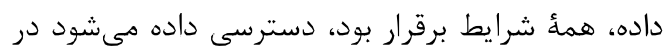

$$
\text { غير اينصورت دسترسى رد مىشود. }
$$

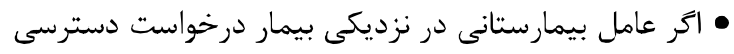

به اطلاعات او را داشته باشد:

RFID reader اكر در بخش اورزانس باشد با استفاده الهان

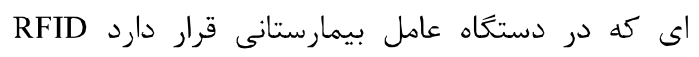

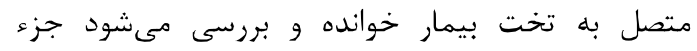

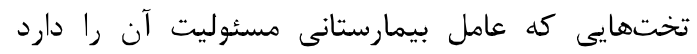

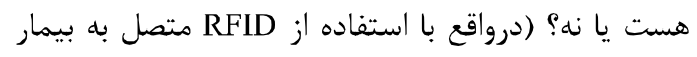

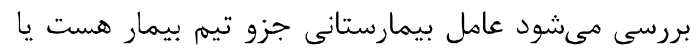

(d)

- شرايط اضطرارى و شرايط مكانى و زمانى كفتهشده در

$$
\text { حالت قبل بررسى مى إشود. }
$$

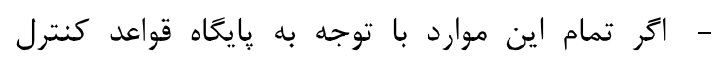

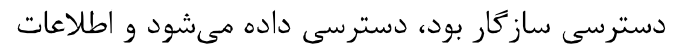

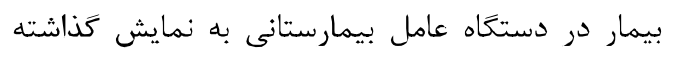

$$
\text { مىشود؛ در غير اينصورت دستر سى رد مىشود. }
$$

دسترسى به اطلاعات بيمار را با استفاده از شناسه (يا نام)

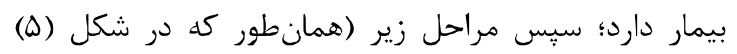

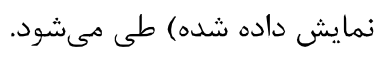

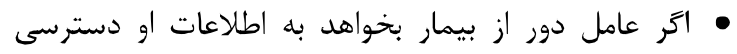

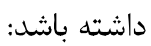

- ابتدا مكان بيمار بررسى مىشود كه آيا در اورزانس

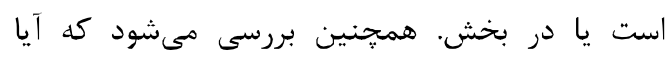

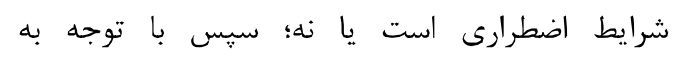

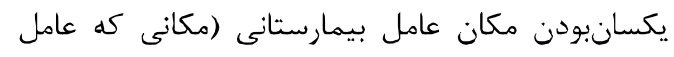

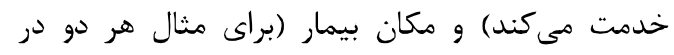

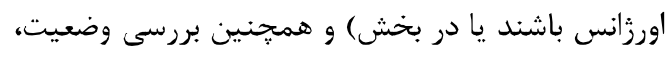

$$
\text { درخواست وارسى مىشود. }
$$

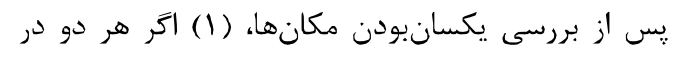

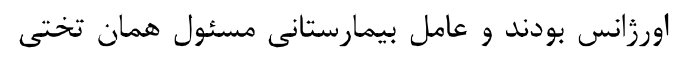

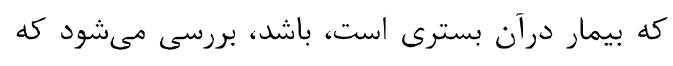

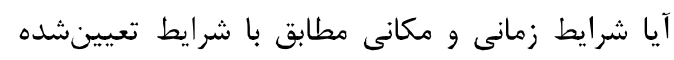

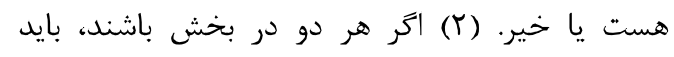

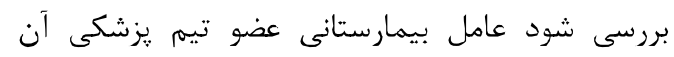

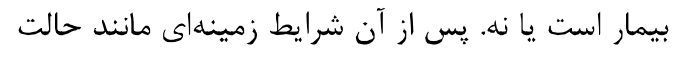

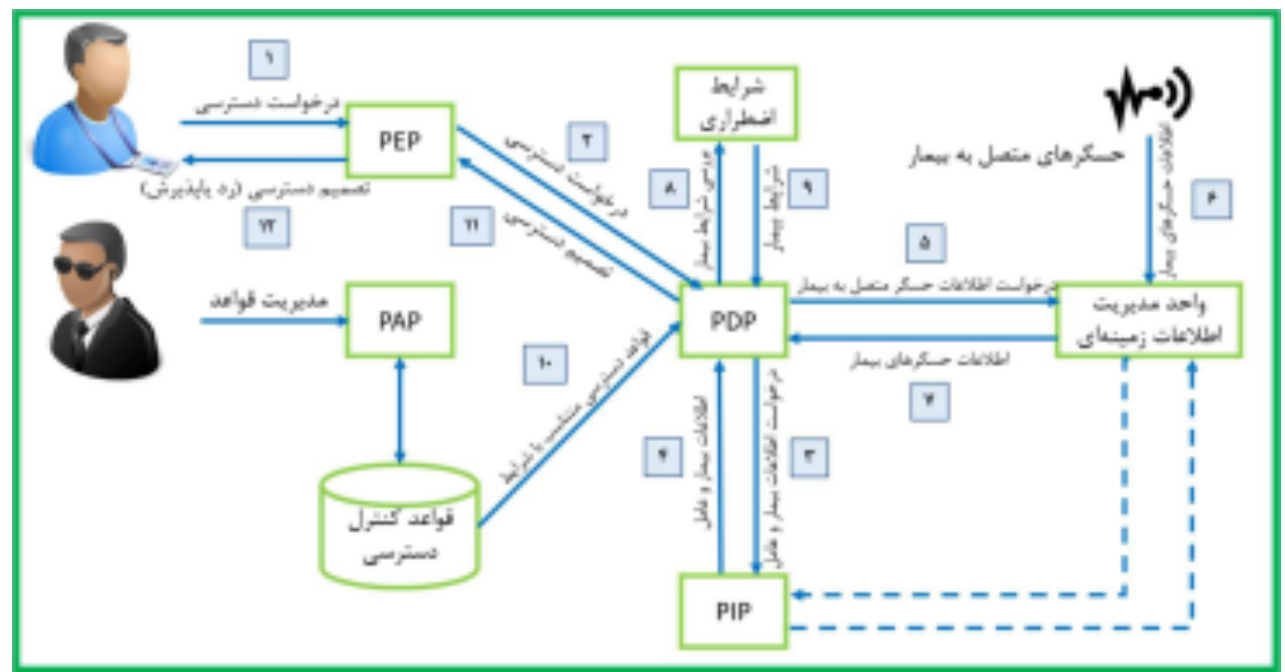

(شكل-)

(Figure-6): Access control framework

كاركنان جهت توصيف قواعد و خطمشىهاى امنيتى فراهم

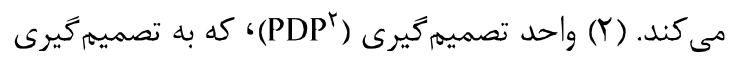

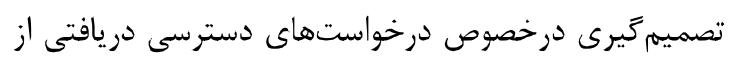

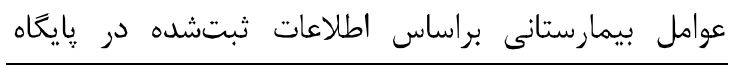

${ }^{1}$ Policy Administrator Point

2 Policy Decision Point

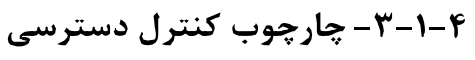

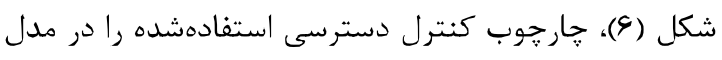
TbDAC تأمين كنترل دسترسى در سلامت الكترونيكى حضور دارند دارند كه عبارتند از:

(1) واحد مديريت خطمشى (PAP')، كه واسطى را براى 
براى بيان دقيقتر قواعد كنترل دسترسى بايد ابتدا

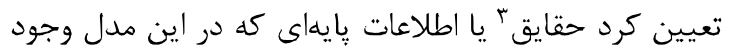

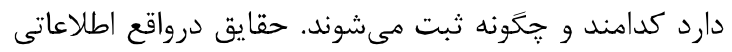

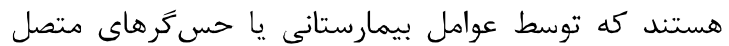
به بيمار ثبت مىشوند. • اطلاعاتى كه توسط سريرستار ثبت مي بـشود:

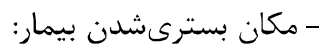

AssignedLocationP (P, PL)

مكان بسترىشدن بيمار P با Pاستفاده از مسند AsssignedLocationP

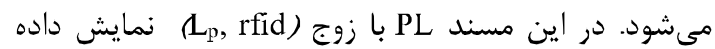

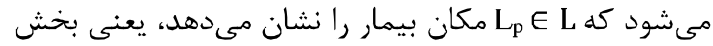

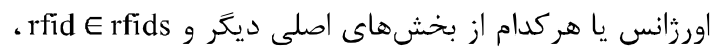
برجسب متصل به بيمار (در بخش اصلى) يا تخت بيمار (در إن بخش اورزانس) را نمايش مى دهد.

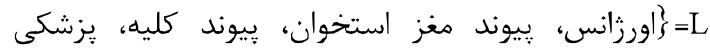
هستهاى، جراحى هغز و اعصاب، جراحى قلب و ييوند قلب، اطفال و م....

rfids = مجموعه برجسبهاى شناسايى كه افراد يا تختها

\section{PL $\in \mathrm{L} \times$ rfids}

$$
\text { به آن مجهز مي شوند. }
$$

$$
\text { - مكان تحت نظر (مسئوليت) عوامل بيمارستانى: }
$$

AssignedLocationS (S, SL)

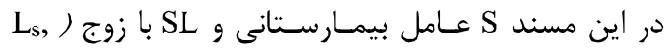

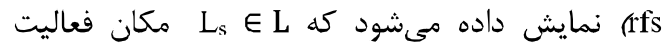

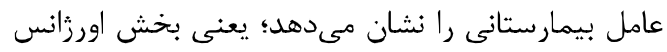

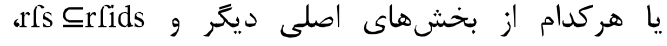

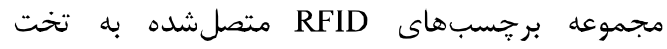
بيماران (در بخش اورزانس) و خود بيماران (دران بخشهاى اصلى) را كه عامل بيمارستانى مسئول $\mathrm{SL} \in \mathrm{L} \times 2^{\text {rfids }}$

$$
\text { رسيدگى به آنها است، نمايش مى دهد: }
$$

- عضويت بيمار P و عامل بيمارستانى S در يك تيم: IsMemberOfTeam (S, P)

$$
\text { - زمان كارى عوامل بيمارستان در بازه زمانى: }
$$

TimeTable (S, $\left.\mathrm{t}_{1}, \mathrm{t}_{2}\right)$

- برجسب RFID اى كه به هر بيمار مانند Pنسبت داده

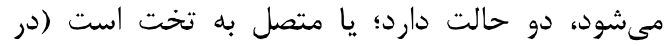

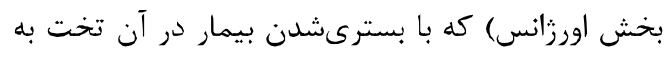

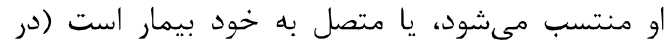

$$
\text { بخش هاى اصلى). }
$$

AssignedRFID (P, rfid)

${ }^{3}$ facts

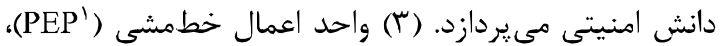

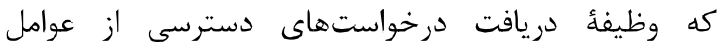

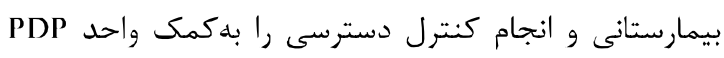

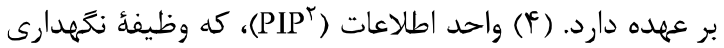
نكَهدارى اطلاعات عامل بيمارستانى درخواستدهنده و و بيمار

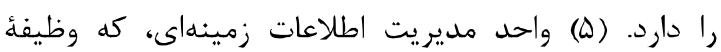
جمع آورى اطلاعات زمينهاى مانند مكان عامل بيمارستانى و واري

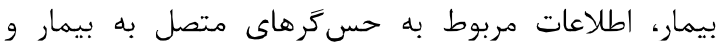
متصل به بيمار يا تخت بيمار را برعهله دارد. RFID

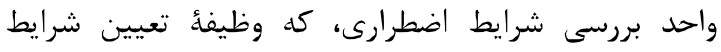

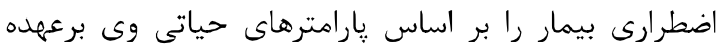
دارد. در شكل (9)، روند كنترل دسترسى از زمان دان درخواست

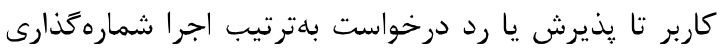
شده است.

ه-1-r- قواعد دسترسى در شرايط عادى

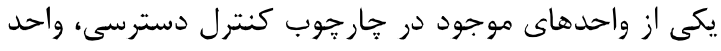

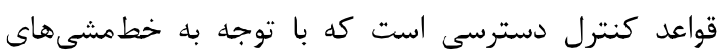
بيمارستان و مدل هاى كنترل دسترسى توسط مديريت قواعد

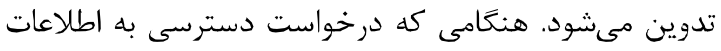
بيمار توسط يكى عامل بيمارستانى داده مىشود، بـ با استفاده از

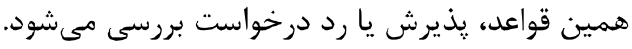
قواعد كنترل دسترسى را مىتوان در دو وضعيت مختلف درد درد

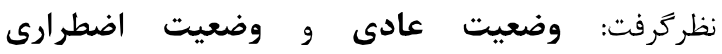
(اورزانس). هر كدام از اين شرايط ممكن است در قسمت اوررانس يا بخشهاى مختلف بيمارستان اتفاق بيافتد (شكل

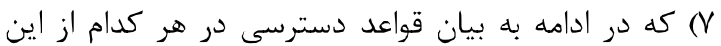

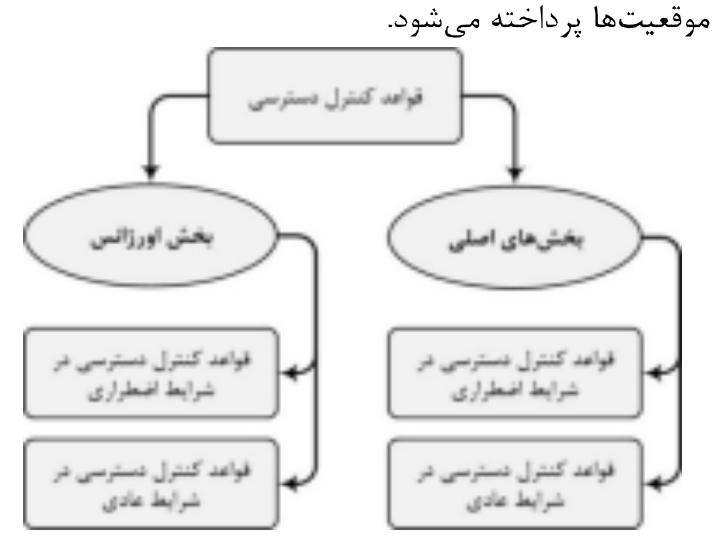

(شكل-V) انواع قواعد دسترسى : (1)

(Figure-7): Access control rules categories

\footnotetext{
${ }^{1}$ Policy Enforcement Point

${ }^{2}$ Policy Information Point
} 


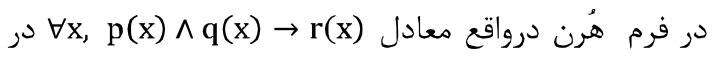
منطق مرتبه نخست است. مسأله استنتاج در فرم هرم هرنِ

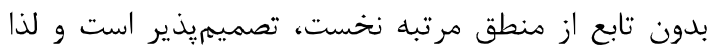

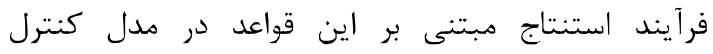
دسترسى بيشنهادى نيز تصميميذير است. • تعريف قاعده دسترسى در بخش اورزانس:

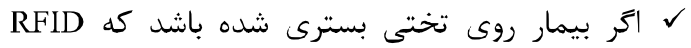

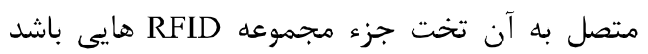

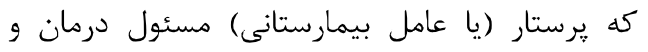

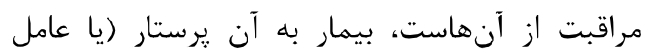

$$
\text { بيمارستانى) منتسب ميى انهود. }
$$

Patient $(\mathrm{p}) \wedge \operatorname{Staff}(\mathrm{s}) \wedge$ AssignedLocation $\mathrm{P}(\mathrm{p}$, $(1 \cdot)$ $\mathrm{PL}) \wedge \wedge$ ssignedLocations $(\mathrm{s}, \mathrm{SL}) \wedge \operatorname{InSubset}(\mathrm{PL}$, $\mathrm{SL}) \rightarrow \operatorname{Assign}(\mathrm{p}, \mathrm{s})$

ل اخر عامل بيمارستانى مسئول يك بيمار باشد، با توجه

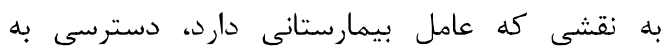
بخشهاى مختلف از اطلاعات بيمار به او داده مىشود.

$\Lambda \operatorname{ssign}(p, s) \wedge$ isOwnedBy( res, $p) \wedge$ Type ( res, res-Type) $\wedge$ hasRole $(s, r) \wedge$ CurrentTime $(\mathrm{t}) \wedge$ TimeTask $\left(\mathrm{s}, \mathrm{t}_{1}, \mathrm{t}_{2}\right) \wedge\left(\mathrm{t}_{1} \leq \mathrm{t} \leq \mathrm{t}_{2}\right) \wedge$ AssignedPermission ( $r$, a, res-Type) $\rightarrow$ CanAccess $(\mathrm{s}, \mathrm{a}, \mathrm{res})$

\section{• تعريف قاعدهُ دسترسى در بخش هاى اصلى:}

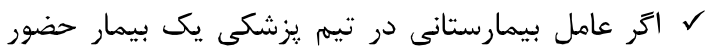

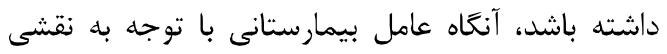
كه در آن تيم دارد به اطلاعات بيمار دسترسى خواهد

$$
\text { داشت. }
$$

HasTeam $(p, t m) \wedge$ Membership $(s, t m$,

r) $\wedge$ CurrentTime $(t) \wedge$ TimeTask $\left(s, t_{1}, t_{2}\right) \wedge\left(t_{1} \leq t\right.$ $\left.\leq \mathrm{t}_{2}\right) \wedge$ IsOwnedBy( res, p) $\wedge$ Type ( res, res-Type) $\wedge$ AssignedPermission ( $r$, a, res-Type $) \rightarrow$ CanAccess ( s, a, res)

\section{צ-1-" - قواعد دسترسى در شرايط اضطرارى}

مجموعهاى از شرايط و علايم حياتى مربوط به بيمار وجود سودايط

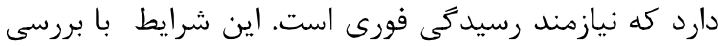
مقادير يارامترهاى حياتى بيمار (كه از طريق حسى درهائى كه

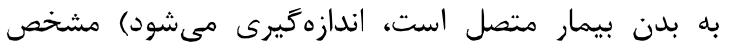

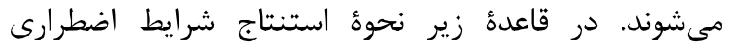
$\bigwedge_{\mathrm{i}}[\mathrm{Ci}(\mathrm{P}, \mathrm{V}) \wedge \mathrm{V} \Theta \mathrm{T}] \rightarrow \operatorname{IsEmergency}(\mathrm{P})$

$$
\text { توصيف شده است: }
$$

$O=\{=,<,>, \leq \geq\}$
اطلاعات قابل ثبت توسط حسگرها:

- اطلاعات حياتى بدن بيمار:

$\mathrm{C}_{\mathrm{i}}(\mathrm{P}, \mathrm{V})$

كه در آن مسند C نوعى از اطلاعات مانند دماى بدن مربوط به بيمار، ضربان قلب و فشار خون او است و V V

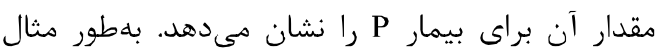
Pressure(Ahmadi, 14)

$$
\text { بيمار احمدى فشار خون عال را دارد. }
$$

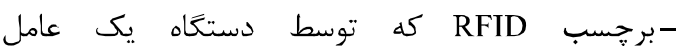

\section{RFID (rfid, S)}

$$
\text { بيمارستانى مانند S خوانده مىشوه: }
$$

كه در آن rfid، مقدار برجسب خواندهشه بلهوسيلة

مربوط به عامل بيمارستانى SFID reader

علاوهبر حقايق و اطلاعاتى كه ثبت مىشود، اطللاعاتى بـ ئه

نيز از طريق اين حقايق استنتاج مىشود كه در ادامه به

$$
\text { تعريف آنها میىيردازيم: }
$$

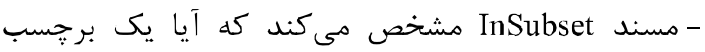

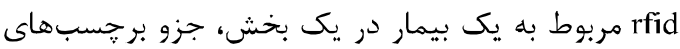

تحت مسئوليت يك عامل بيمارستانى هست يا نه:

$\mathrm{SL}=\left(\mathrm{L}_{\mathrm{s}}, \mathrm{rfs}\right) \wedge \mathrm{PL}=\left(\mathrm{L}_{\mathrm{p}}, \mathrm{rfid}\right) \rightarrow$

(InSubset $(\mathrm{PL}, \mathrm{SL})=$ True $\leftrightarrow\left(\mathrm{L}_{\mathrm{p}}=\mathrm{L}_{\mathrm{s}}\right) \wedge$

(rfid $\in \mathrm{rfs})$ )

قواعد درشرايط عادى در دو حالت قابل بررسى است:

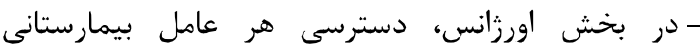
(يرستاران و يزشك اورزانس) به اطلاعات، از قبل تعيين شده است؛ به اين شكل كه هر عامل مسئول مجموعهاى

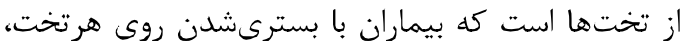

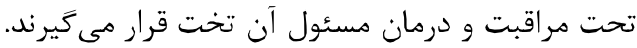
- در بخشهاى اصلى، دسترسى با عضويت در تيمهاى يزشكى مشخص مىشود. به اين شكل كه هر هر عامل بهل بيمارستانى كه عضو تيم يزشكى مربوط به يكى بيمار شود

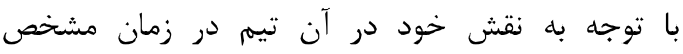
مىتواند به اطلاعات بيمار دسترسى داشته باشد. بلهور كلى در جدول (1) تمام مسندهاى استفادهشده در قواعد دسترسى آورده شده و در ادامه توصيف قواعد دسترسى در بخشهاى مختلف ارايه شده است. كفتنى است كه در توصيف قواعد دسترسى در ابن مقاله، از قاعدههاى به فرم هُرن بدون تابع ' استفاده شده است. توجه كنيد كه در فرم هُرن، بلطور ضمنى سور عمومى وجود دارد، يعنى به طور مثال قاعده (x)

${ }^{1}$ Function-free Horn Clause 


\begin{tabular}{|c|c|}
\hline مسند & توضيحات \\
\hline AssignedLocationP(p, PL) & Pان بيمار p در قالب PL \\
\hline AssignedLocationS (s, SL) & مكان انجام وظيفهى عامل بيمارستانى s در قالب SL \\
\hline Assign(p,s) & انتساب بيمار p به عامل بيمارستانى s \\
\hline TimeTask $\left(\mathrm{s}, \mathrm{t}_{1}, \mathrm{t}_{2}\right)$ & زمان شيفت كارى عامل بيمارستانى s در بازه t t \\
\hline CurrentTime(t) & زمان جارى را به t منتسب مى كند و همواره True برمى كرداند. \\
\hline CurrentDate(d) & تاريخ جارى را به d منتسب مى كند و همواره True برمى كر داند. \\
\hline HasRole(s,r) & انتساب نقش r به عامل بيمارستانى \\
\hline Role-Purpose(r, pu) & انتساب هدف pu به نقش r r \\
\hline InSubset (PL, SL) & مكان بيمار p زيردجموعه مكان تحت مراقبت عامل بيمارستانى \\
\hline IsMemberOfTeam $(\mathrm{s}, \mathrm{p})$ & عضو بودن عامل بيمارستانى s در تيم يزشكى بيمار p در بخش اصلى \\
\hline Preference(p, res-Type, pu) & res-Type در قرجيحات بيمار pu به به الب اختصاص هدف \\
\hline AssignedRFID (p, rfid) & p اختصاص برجسب rfid به بيمار p \\
\hline RFID (rfid, s) & Aناسايى برجسب rfid توسط عامل بيمارستانى sid \\
\hline IsOwnedBy(res, $\mathrm{p})$ & p اختصاص اطلاعات res به بيمار p \\
\hline Type(res, res-Type) & res-Type انتساب منبع قاده res به نوع \\
\hline AssignedPermission ( $r$, a, res-Type) & انتساب فحاليت a بر روى res-Type به نقش r r \\
\hline CanAccess (s, a, res) & امكان دسترسى عامل بيمارستانى s به فعاليت a بر روى منبع res \\
\hline HasTeam $(\mathrm{p}, \mathrm{tm})$ & انتساب تيم tm به بيمار p \\
\hline Membership (s, tm, r) & انتساب نقش r در تيم يزشكى tm به عامل بيمارستانى st \\
\hline Request (s, a, res) & 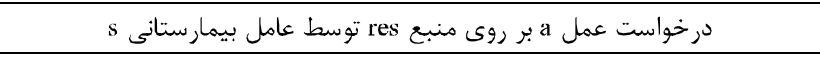 \\
\hline IsEmergency (p) & تعيين شرايط اضطرارى بيمار p \\
\hline HosPurpose (pu, res-Type) & res-Type تعريف سياست بيمارستان در قالب انتساب هدف به به \\
\hline Can $\Lambda$ ccessP $(\mathrm{s}, \mathrm{a}, \mathrm{res}, \mathrm{pu})$ & امكان دسترسى عامل بيمارستانى s به عمل a بر روى منبع res با هدف نسترسى \\
\hline PRequest(s, a, res, pu) & درخواست عمل a بر روى منبع res توسط عامل بيمارستانى s با هدف دسترسى \\
\hline Delegate $\left(\mathrm{s}_{1}, \mathrm{~s}_{2}, \mathrm{r}, \mathrm{tm}\right.$, startTime, endTime $)$ & 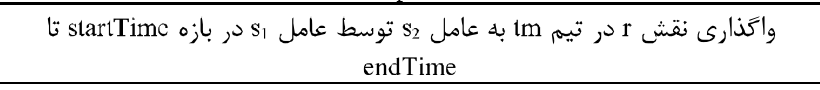 \\
\hline Fetch(s, a, res, pu) & واكشى اطلاعات براى عامل s با انجام عمل a بر روى منبع res با هدف دسترسى \\
\hline
\end{tabular}

(جدول -1): تعريف مسندها

(Table-1): Definition of predicates

زمانى كه يك عامل بيمارستانى درخواست دسترسى به

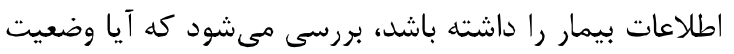

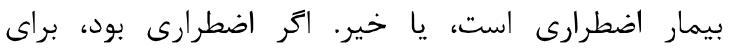

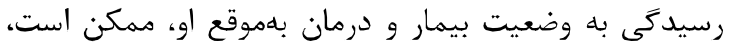

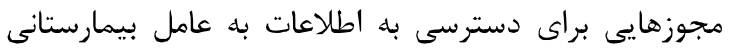
داده شود كه در وضعيت عادى اين مجوزها را نداشته است.

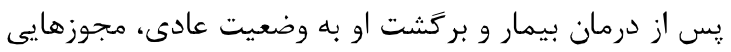

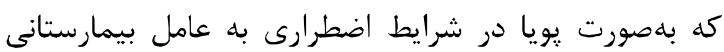

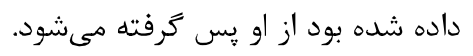

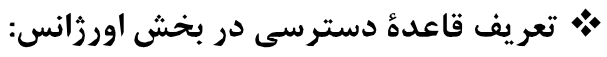

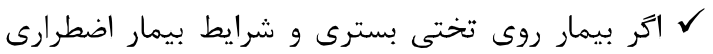

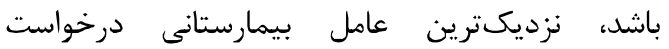

در اين قاعده، i

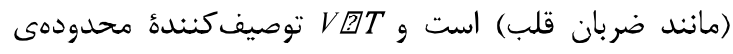

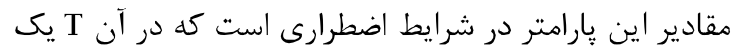

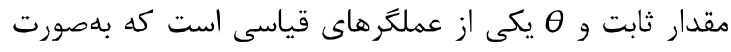

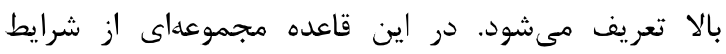
مرتبط با يارامترهاى حياتى مختلف در نظر كرفته شده است

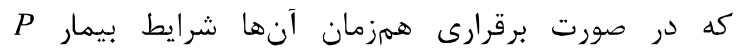

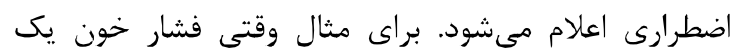

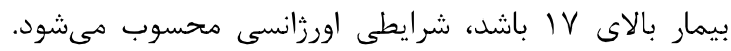

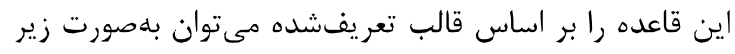
توصيف كرد: - (ين Pressure $(P, V) \wedge V>17 \rightarrow I s E m e r g e n c y(P)$ 
قوانين تصويبشده در سازمانهاى بالادستى براى

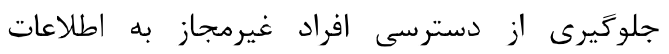
بيماران را در نظر داشته باشد [25] دان.

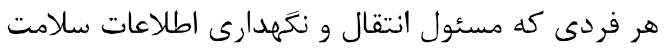

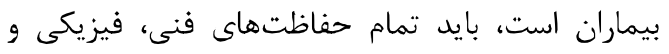

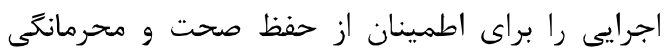

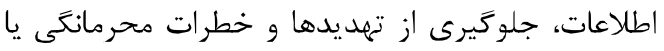

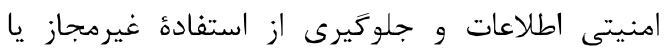
افشاى اطلاعات، اعمال كند [25]. عوامل بيمارستانى در شرايط اضطرارى و احياى بيمار،

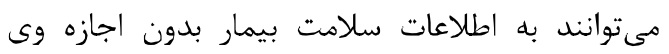
دستر سى داشته باشند [26].

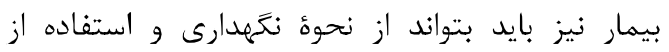

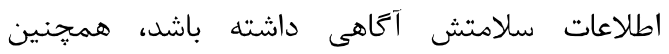

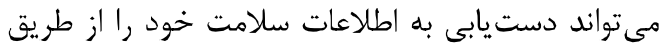
مديريت كليدهاى رمزكذارى كنترل كند [27].

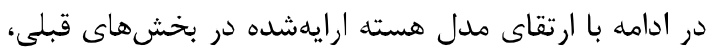

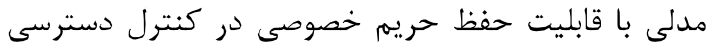
به اطلاعات سلامت الكترونيكى بيماران ارايه مىشود.

\section{I-Y-r-r- فر آيندهاى درمانى با حفظ حريم خصوصى}

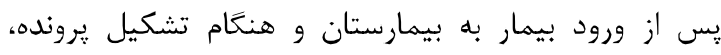

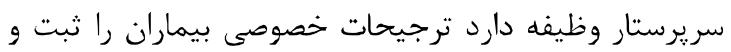
بر اساس آن تيم يزشكى و شرايط مناسب را براى برائ بيمار

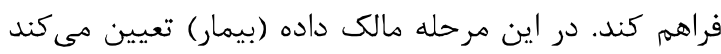

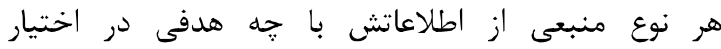

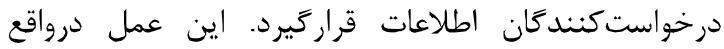

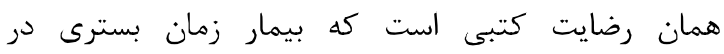

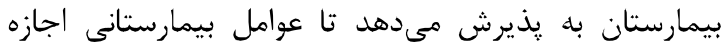

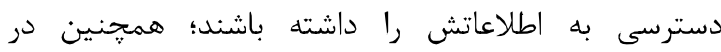
بيمارستانها خطمشى هايى براى خدماترسانى با كيفيت و سريعتر به بيماران با توجه به خطمشى هاى كلى وزئه وزارت

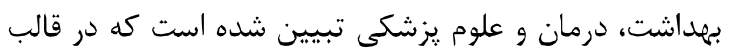
مجوزهاى دسترسى براى اهداف مختلف تعريف مى شيود.

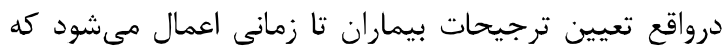
در اجراى رسالت اصلى بيمارستان خللى وارد نكردد. بهطور كلى بيمارستانها به دو نوع تقسيم مىشوند: بيمارستانهاى آموزشى - درمانى و بيمارستانهاى فقط دوران

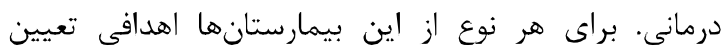

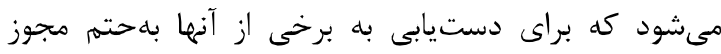

دسترسى به اطلاعات بيمار را مىدهد و با توجه به نقشى كه دارد و نزديكى او به بيمار (كه با استفاده از

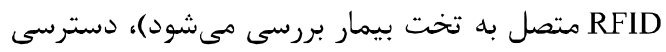

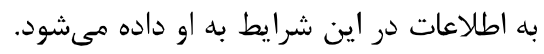

Request $(s, a$, res $) \wedge$ CurrentTime $(t) \wedge$

TimeTask $\left(s, t_{1}, t_{2}\right) \wedge\left(t_{1} \leq t \leq t_{2}\right) \wedge I_{s} O$ wnedBy $($ res , p) $\wedge$ Type (res, res-Type $\wedge$ IsEmergency $(p) \wedge$ RFID ( rfid, s) $\wedge$ AssignedRFID ( $p, r f i d) \wedge$ HasRole $(s, r) \wedge$ AssignedPermission ( $r$, a, res-Type) $\rightarrow$ CanAccess ( $s, a$, res)

توجه كنيد كه طبق اين قاعده با توجه به شرايط اضطرارى

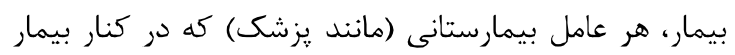

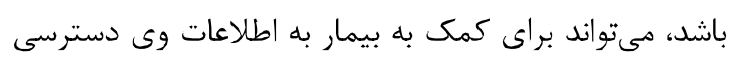

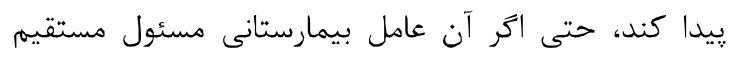

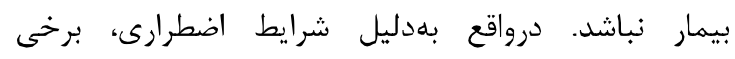

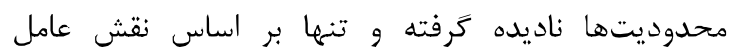
بيمارستانى دسترسى ها اعطا مى شوده.

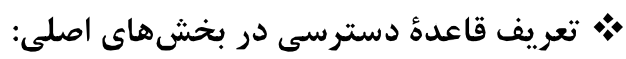

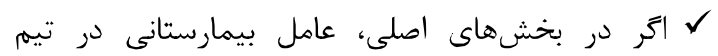

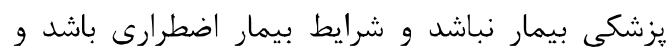

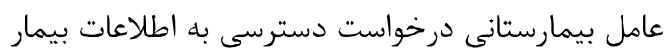

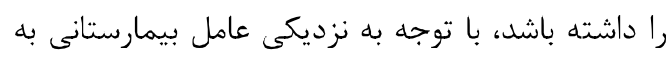

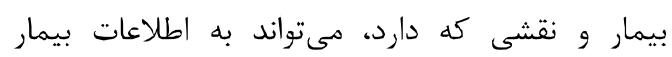
دسترسى داشته باشد.

Request $(s$, a, res $) \wedge$ CurrentTime $(t) \wedge$

TimeTask $\left(s, t_{1}, t_{2}\right) \wedge\left(t_{1} \leq t \leq t_{2}\right) \wedge I_{s}$ OwnedBy $($ res, p) $\wedge$ Type (res, res-Type $) \wedge I$ IsEmergency $(p) \wedge$ RFID (rfid, s) $\wedge$ AssignedRFID ( $p$, rfid) $\wedge$ HasRole $(s, r) \wedge$ AssignedPermission $(r$, a, res-Type $) \rightarrow$ CanAccess ( $s, a$, res)

\section{TbDAC 1 -r - مدل حافظ حريم خصوصى} حفظ و نكَهدارى اطلاعات و حريم خصوصى بيماران از جمله

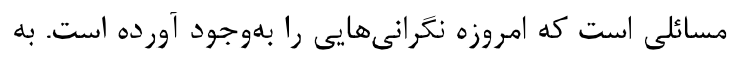
همين دليل در سال 1999 استاندارد HIPAA (قانون انتقال

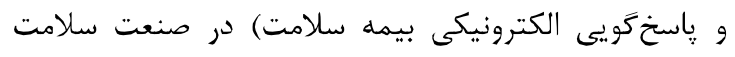

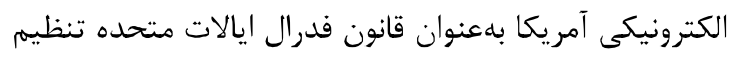
شد. در بخش مربوط به استانداردهاى امنيتى اين قانون آمده

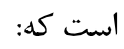
سازمان بايد در راهاندازى سامانه ثبت اطلاعات مربوط

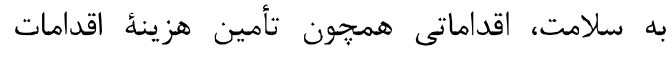

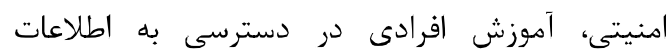
سلامت بيماران و سازوكارهايى جهت تضمين رعاديت درست 
هنكامى كه بيمار زير سن قانونى است و يا در زمانى كه

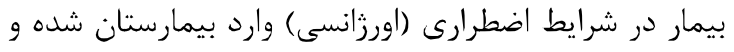

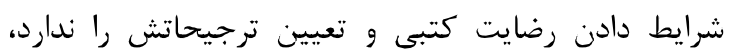
والدين يا فاميل درجة يك او تعيين مى كنند كه هركدام از

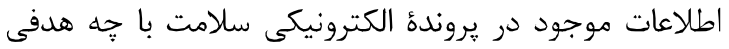

$$
\text { مى تواند در دسترس درخواست كنند مان قرار كيرد. }
$$

\section{TbDAC 1 r-r-r-r- تعريف مدل دادهاى} براى حفظ حريم خصوصى در اين مدل، دو مؤلفهُ هدف و

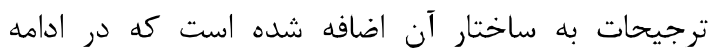

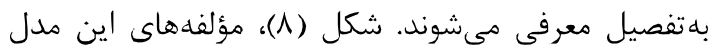

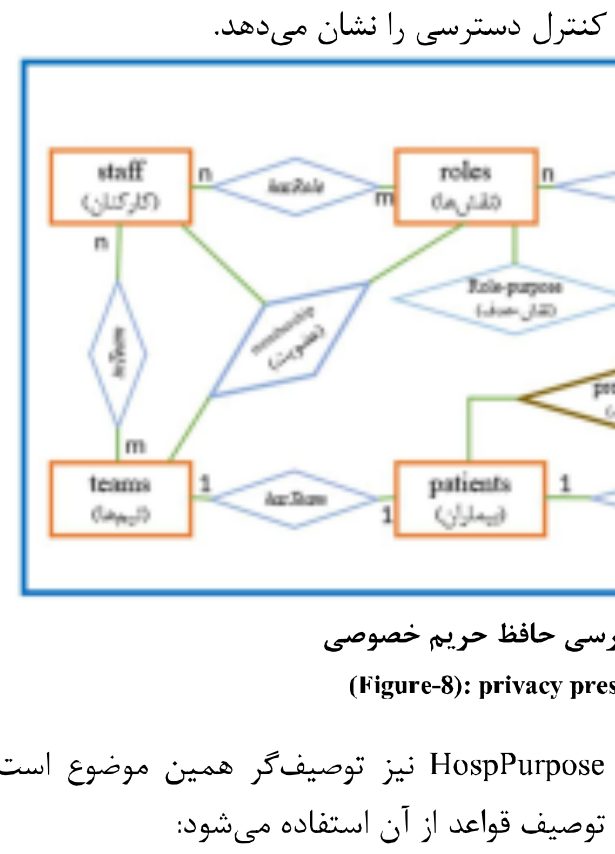

توصيف قواعد از آن استفاده مىشود:

hospPurpose $\subseteq$ purposes $\times$ res-type

$\operatorname{HospPurpose}(\mathrm{pu}, \mathrm{rt})=$ True $\leftrightarrow(\mathrm{pu}, \mathrm{rt}) \in$

hospPurpose

رابطة hospPurpose درواقع با توجه به خطمشىهاى بيمارستان و نيازمندىهايى كه براى دسترسى به دادههاى بيماران براى انجام بهتر رسالت خود دارد تعريف مىشود و

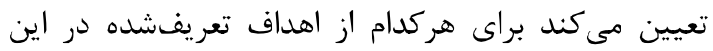

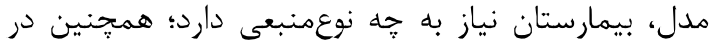

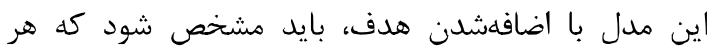

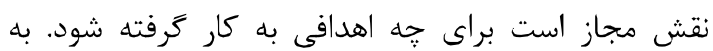
همين منظور رابطة مجأ بهصورت زير تعريف

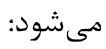
role-Purpose $\subseteq$ roles $\times$ purposes Role-Purpose $(r, p)=$ True $\leftrightarrow(r, p) \in$ role-Purpose
دسترسى به نوعمنبعهاى مشخصى از بيماران بايد وجود داشته باشد؛ مانند هدف درمانى؛ اما براى برخى اهداف ماف مانئد

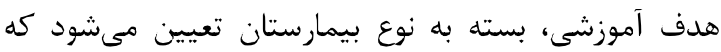
مجوز دسترسى به اطلاعات بيماران لازم است يا نه. بهعنوان بهان مثال براى بيمارستانهاى آموزشى - درمانى اكر بيمار اجازئ

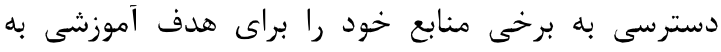

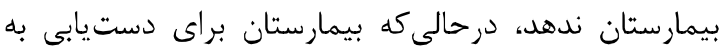

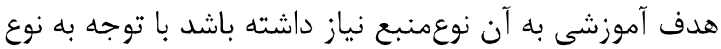
بيمارستان اين ترجيح بيمار در نظر ترفته نمىشود؛ اما اتر همين شرايط در بيمارستان فقط درمانى باشد، ترجيح بيمار ثبت شده و بيمارستان اجازه ندارد از منابع بيمار براى هدف آموزشى استفاده كند.

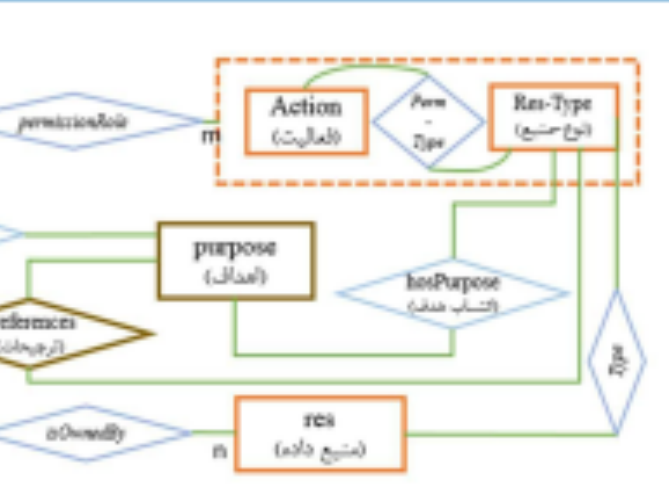


r-Y-r- فرآيند كنترل دسترسى حافظ حريم خصوصى

زمانى كه هركدام از عوامل بيمارستانى درخواست خود راسي

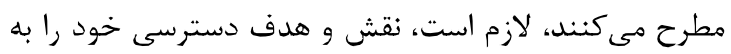

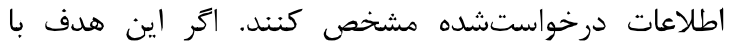

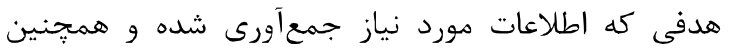

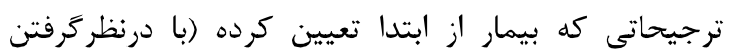

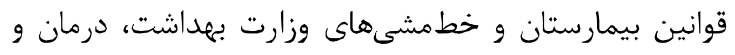
علوم يزشكى) هطابقت داشته باشد، درخواست يذيرفته و وران درغيراينصورت رد مىشود.

F-F-F - قواعد دستر سى در شر ايط عادى

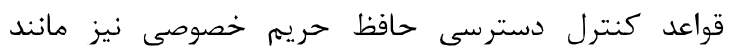
حالت هسته در دو وضعيت عادى و اضطرارى مورد ارزيابى نئ

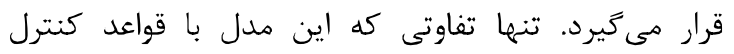
دسترسى در مدل قبل دارد اين است كه هنعَام درخواست

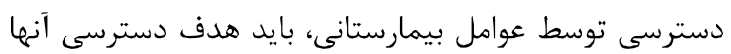

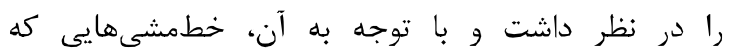

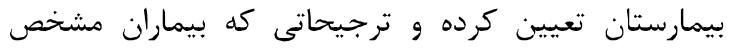

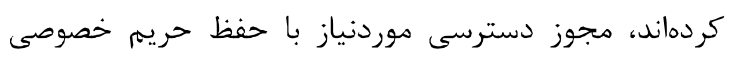
بيمار به عامل بيمارستانى اختصاص يابد.

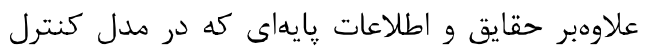

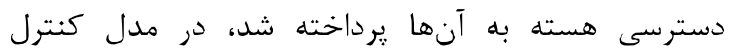

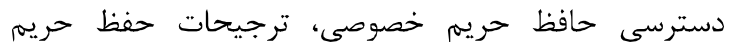

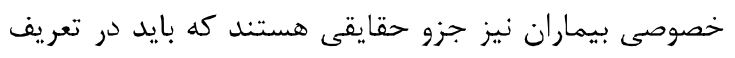
قواعد دسترسى مورد توجه قرار گيرند؛ لذا حقايقى با استفاده

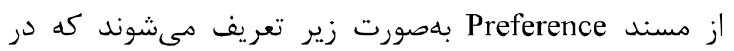
فرآيند كنترل دسترسى به كار خرفته مىشوند: Preference(P, Res-Type, Pu)

بس از تعريف اين ترجيحات توسط بيمار، با توجه بـ

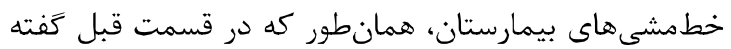

شد، در صورت لزوم ترجيحات باز تعريف مى شوندان

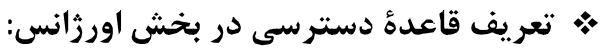

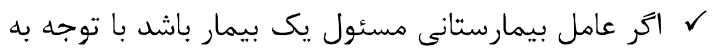

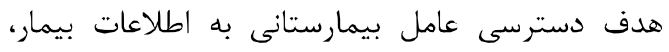

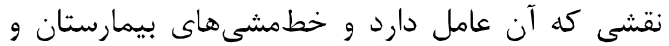

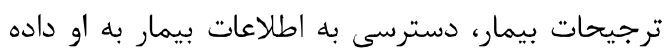

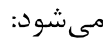
Assign (p, s) $\wedge$ CurrentTime (t) $\wedge$

TimeTask $\left(s, t_{1}, t_{2}\right) \wedge\left(t_{1} \leq t \leq t_{2}\right) \wedge$ IsOwnedBy $($ res, $p) \wedge \operatorname{Type}($ res, res-Type $) \wedge$ HasRole $(\mathrm{s}, \mathrm{r}) \wedge$ Role-Purpose $(\mathrm{r}, \mathrm{pu}) \wedge$
هدف دسترسى (Access Purpose) كه يِشتر عنوان شده بود نيز هدفى است كه عامل بيمارستانى هنگام درخواست دسترسى به اطلاعات بيمار آن را مشخص مى كند و در زمان بررسى درخواست بررسى مىشود كه ائه اين هدف،

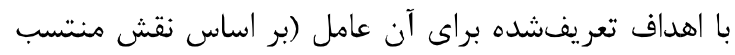

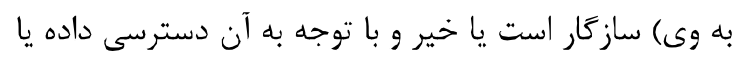
رد مىشود. درعمل هنعامى كه عامل وارد سامانه مىشود،

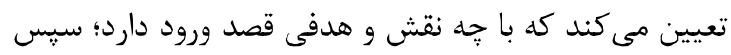
بررسى مىشود كه با اين نقش تعيينشده، عامل مجوز دسترسى به اطلاعات با هدف تعيينشده را دارد يا نه؟ كه در برد صورت مجازبودن ادامةٌ روند درخواست براى عامل انجام

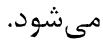
ترجيحات: در اين مدل هر بيمار هنغام تشكيل يرونده

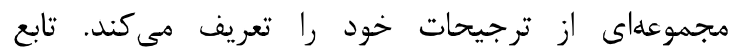
preferences مى كند و بهصورت صورى زير تعريف مىشود: preferences: patients $\rightarrow 2$ res-typex purposes

$\operatorname{Preference}(\mathrm{p}, \mathrm{rt}, \mathrm{pu})=\operatorname{Truc} \leftrightarrow(\mathrm{rt}, \mathrm{pu}) \in$ preferences $(p)$

بايد توجه شود ترجيحاتى كه بيماران براى حفظ حريم

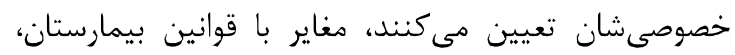

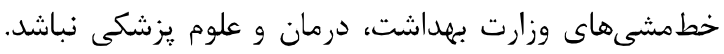

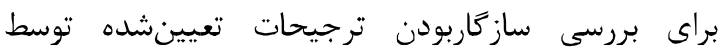
بيماران با خط مشىهاى تعريفى بيمارستان، لازم است بررسى شود كه براى هر نوع منبع دادهاى كه بيمارستان

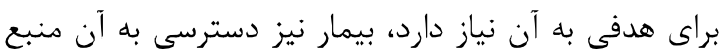
رادر ترجيحاتش براى هدف موردنظر مجاز دانسته باشد. $\forall p \in$ patients, $\nexists$ pu $\in$ purposes, (pu, rt) $\in$

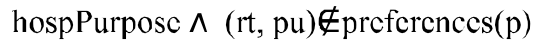

اتر اين رابطه درست نباشد يعنى منبعى وجود داشته باشد

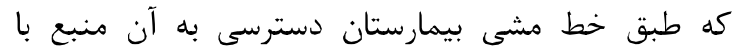
هدفى خاص موردنياز باشد، اما بيمار در ترجيحاتش إنى دسترسى به آن منبع را براى هدف موردنظر غيرمجاز بداند با

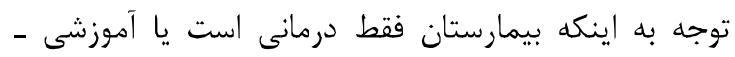
درمانى، تعيين مىشود كه ترجيحات بيمار درنظر كرفته شود انئه

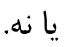

يس از اين بررسى، ترجيحات بيمار با توجه به نتيجل رابطأ بالا باز تعريف مىشود. 
• تعريف قاعدة دسترسى در بخش هاى اصلى:

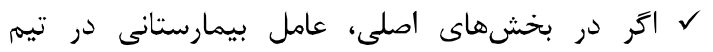

يزشكى بيمار نباشد و شرايط بيمار، اضطرارى و عاهل

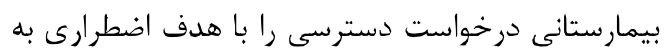

اطلاعات بيمار داشته باشد، با توجه به نزديكى عامل

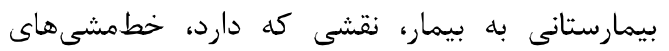

بيمارستان و ترجيحات بيمار، دسترسى به اطلاعات بهات

$$
\text { بيمار به او داده مي شون. }
$$

PRequest ( $s, a$, res, pu) $\wedge$ CurrentTime (t)

(YI)

$\wedge \operatorname{TimeTask}\left(s, t_{1}, t_{2}\right) \wedge\left(t_{1} \leq t \leq t_{2}\right) \wedge$

IsOwnedBy $($ res, $p) \wedge$ Type $($ res, res-Type $) \wedge$

RFID ( rfid, s) $\wedge$ AssignedRFID ( p, rfid) $\wedge$

IsEmergency $(p) \wedge$ HasRole ( s, r) $\wedge$ Role-Purpose

$(\mathrm{r}, \mathrm{pu}) \wedge$ AssignedPermission $(\mathrm{r}, \mathrm{a}$, res-Type $) \wedge$

HosPurpose $(\mathrm{pu}$, res-Type $) \wedge$ Preference $(\mathrm{p}$, res-

Type, pu) $\rightarrow$ CanAccessP ( s, a, res, pu)

r-r- مدل با قابليت وكالت دسترسى TbDAC2

در زمانهايى ممكن است، يزشك بهدليل مرخصى، مدتى را

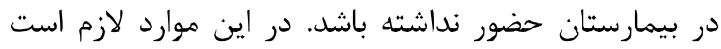

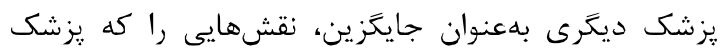

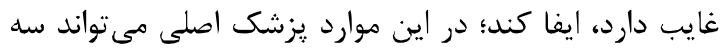

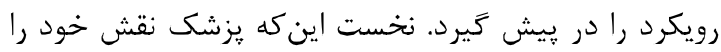

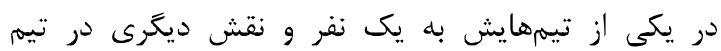
ديخرش را به شخص ديخرى وكالت دهد. دوم اين كه بز بزشك

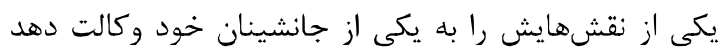
كه در اين حالت يزشك وكيل در همدُ تيمهايى كه يزشك آنس

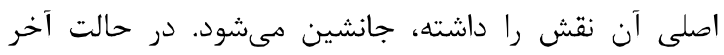
يزشك همةٔ نقشهايش را در همة تيمهايى كه در آنها عضو

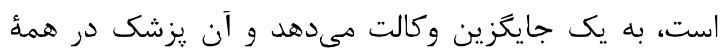
تيمهايى كه يزشك اصلى در آن عضو بوده نقشهايش را را ايفا

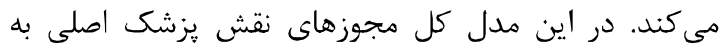

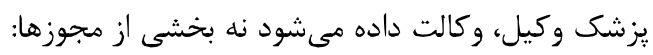

delegates $\subseteq$ staff $\times$ staff $\times$ roles $\times$ teams $\times$ datetime $\times$ datetime

$\left(\mathrm{s}_{1}, \mathrm{~s}_{2}, \mathrm{r}, \mathrm{tm}\right.$, startTime, endTime) $\in$

delegates $\leftrightarrow\left(s_{1}, t m, r\right) \in$ membership $\wedge\left(s_{2}, r\right) \in$ hasRolc

Delegate $\left(\mathrm{s}_{1}, \mathrm{~s}_{2}, \mathrm{r}, \mathrm{tm}\right.$, startTime, endTime $)=$

True $\leftrightarrow$ CurrentDate $(d) \wedge\left(s_{1}, s_{2}, r, t\right.$, startTime, endTime $\in$ delegates $\wedge$ (startTime $\leq \mathrm{d} \leq$ endTime)

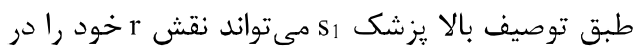

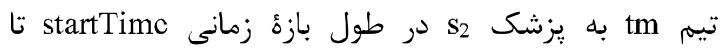
endTime
HospPurpose ( pu, res-Type) $\wedge$ Preference $(p$, resTypc, pu) $\wedge$ AssignedPcrmission ( $r$, a, res-Typc) $\rightarrow$ CanAccessP (s, a, res, pu)

$$
\text { • تعريف قاعده دسترسى در بخشهاى اصلى: }
$$

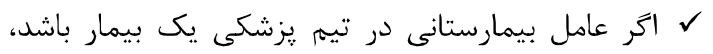

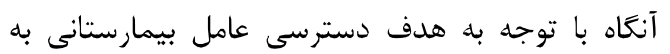

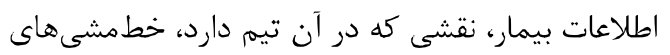

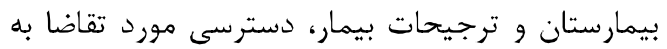

$$
\text { عامل بيمارستانى داده خواهد شد: }
$$

IsOwnedBy( res, p) $\wedge$ Type( res, res-Type)

$\wedge$ CurrentTime $(\mathrm{t}) \wedge$ TimeTask $\left(\mathrm{s}, \mathrm{t}_{1}, \mathrm{t}_{2}\right) \wedge\left(\mathrm{t}_{1} \leq \mathrm{t} \leq\right.$ $\left.t_{2}\right) \wedge \operatorname{HasTeam}(\mathrm{p}, \mathrm{tm}) \wedge \operatorname{Membership}(\mathrm{s}, \mathrm{tm}, \mathrm{r}) \wedge$ Role-Purpose (r, pu)^ HospPurpose (pu, res-

Type) $\wedge$ Preference ( p, res-Type, pu)

$\wedge$ AssignedPermission $(r$, a, res-Type $) \rightarrow$

CanAccessP ( $\mathrm{s}$, a, res, pu)

ه-r-r-r- قواعد دسترسى در شرايط اضطرارى كنترل دسترسى در شرايط اضطرارى در مدل حافظ حريمم خصوصى مانند مدل هستة وجود دارد در اين است كه جون در اين مدل مد بيماران ترجيحاتى را تعيين كردهاند، همجنين طبق تعريف Purpose هر نوعنبعى براى اهداف خاصى جمع آورى شده است، ممكن است درخواستى كه عامل بيمارستانى دارد در شرايط

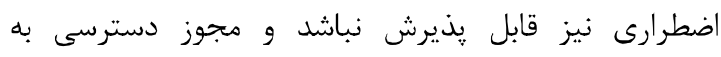

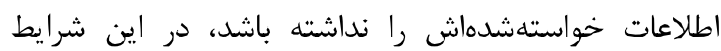
درخواست او رد مىشود.

\section{• تعريف قاعده دسترسى در بخش اورزانس:}

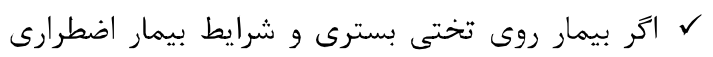

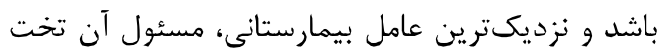

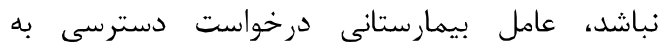

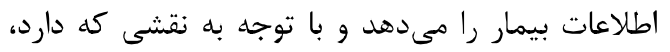
هدف دسترسى اضطرارى او به اطلاعات بيمار، نزديكى

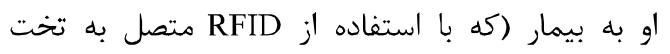

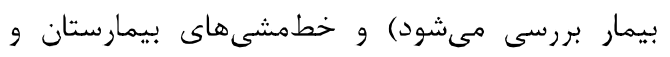

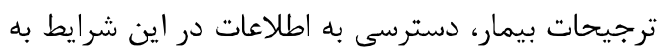

$$
\text { او داده مىشود: }
$$

PRequest ( s, a, res, pu) $\wedge$ CurrentTime $(t) \wedge$

TimeTask $\left(s, t_{1}, t_{2}\right) \wedge\left(t_{1} \leq t \leq t_{2}\right) \wedge$ IsOwnedBy( res, p) $\wedge$ Type (res, res-Type) $\wedge \operatorname{RFID~(rfid,~s)~}$ $\wedge$ AssignedRFID $(p$, rfid $) \wedge \operatorname{IsEmergency~}(p) \wedge$ HasRole $(\mathrm{s}, \mathrm{r}) \wedge$ Role-Purpose $(\mathrm{r}, \mathrm{pu}) \wedge$

HospPurpose $(\mathrm{pu}$, res-Type $) \wedge$ Preference $(\mathrm{p}$, resType, pu) ^ AssignedPermission ( $r$, a, res-Type) $\rightarrow \operatorname{Can} A \operatorname{ccess} P(\mathrm{~s}, \mathrm{a}, \mathrm{res}, \mathrm{pu})$ 
است به جاى مقادير r و t علامت ق* جايكزين شود. در حالتى

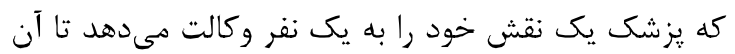

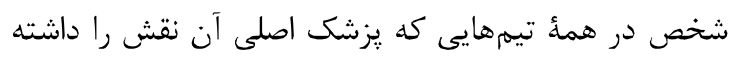

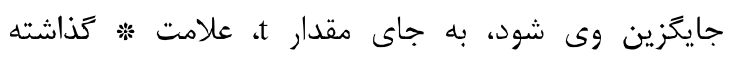

در توصيف بالا مسند CurrentDate(d) تاريخ فعلى راني به متغير d منتسب مى كند و همواره True برمى كرداند. شكل (9)، اين مدل را نشان مي مدهد.

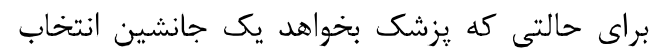

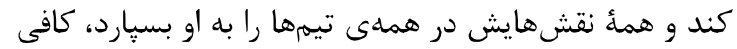

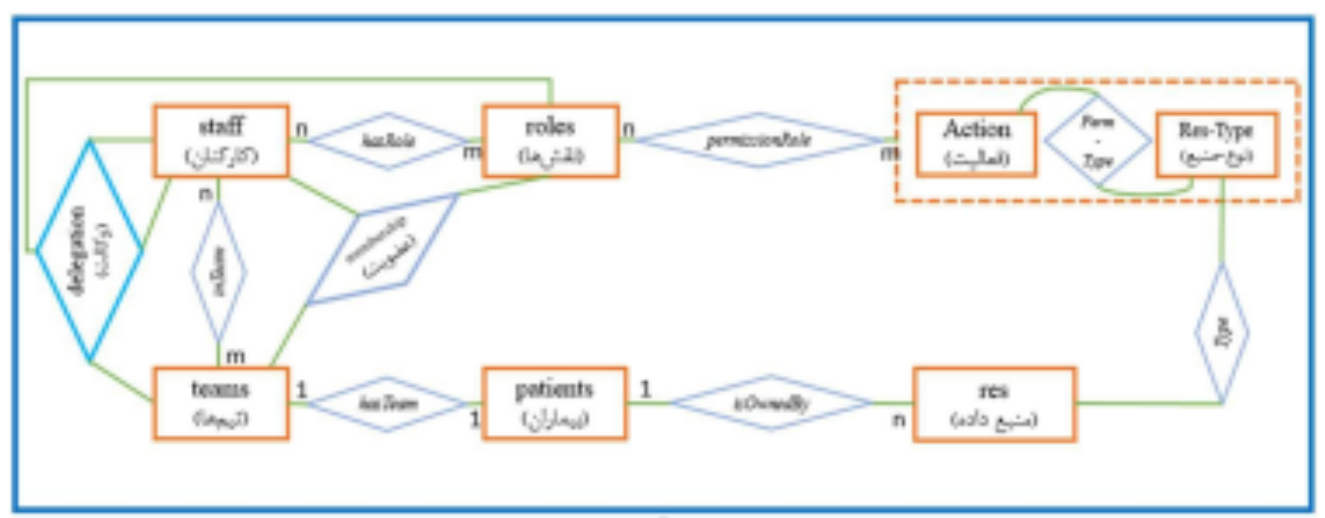

(شكل -9): مدل دادهاى كنترل دسترسى با قابليت وكالت دسترسى :(9)

(Figure-9): access control data model with access delegation

DassignedTeam $\left(\mathrm{s}, \mathrm{t}_{\mathrm{c}}\right)=\left\{\mathrm{tm} \in\right.$ teams $\mid \exists \mathrm{s}^{\prime} \in$ staff, $\exists$ $r \in$ roles, $\exists$ tm $\in$ teams, (s', s, r, tm, startTime, endTime $) \in$ delegates $\wedge\left(\right.$ startTime $\leq t_{c} \leq$ endTime $\left.)\right\}$ و كل تيمهاى يك كاربر در زمان t أز رابطة زير بهدست مى آيد:

AssignedTeams $\left(\mathrm{s}, \mathrm{t}_{\mathrm{c}}\right)=$ assignedTeam $(\mathrm{s}) U$ DassignedTeam $\left(s, t_{c}\right)$

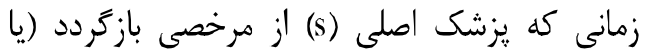
اتمام زمان وكالت) نقش وكالت داده شده به هر وكيل او در هر تيم بايد از وكيل بازيس گرفته شود. براى اين منظور

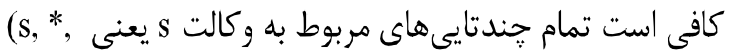

$$
\text { delegates } 11, *, *, *)
$$

ممكن است، در بازماى كه يزشك اصلى حضور ندارد،

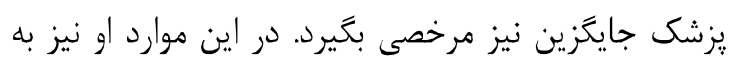

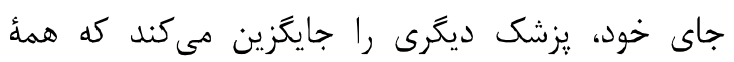
نقشهايش به او واكذار مىشود، حتى نقشهايى كه بلصورت دئري

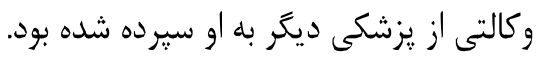

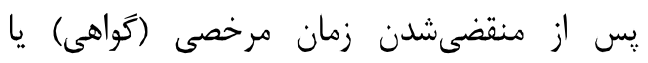
بازگشت يزشك اصلى، گواهى مرخصى باطل مى لشود و تمام

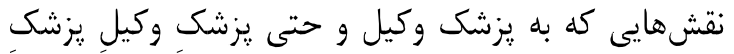

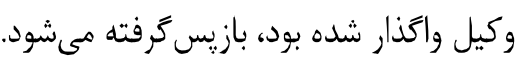

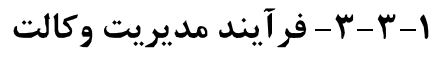

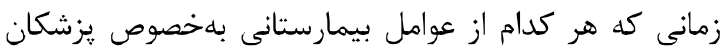

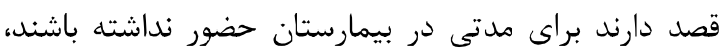

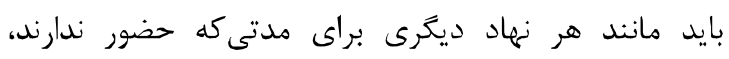

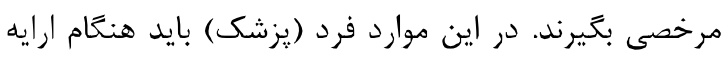

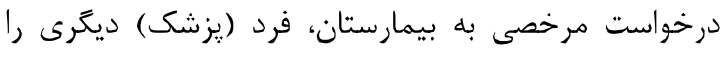

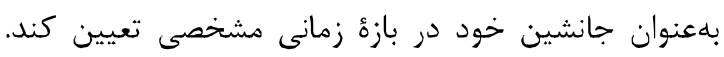

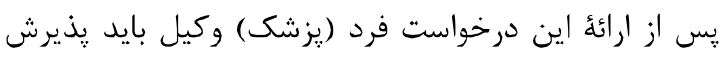

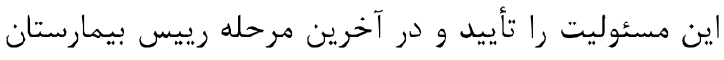

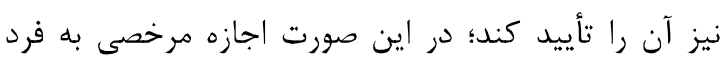

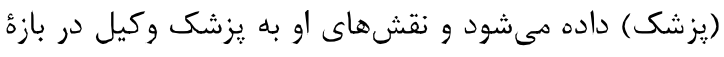

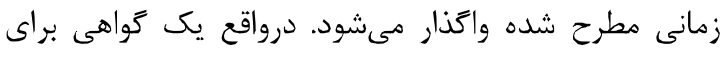

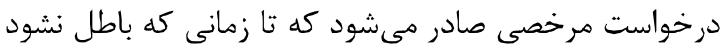

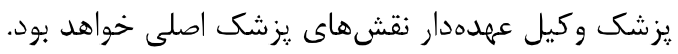
نقشهايى را كه به يك عامل بيمارستانى وكالت داده

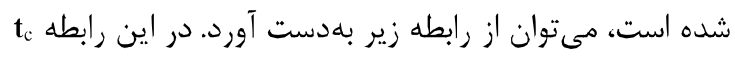

$$
\text { زمان فعلى در نظر ترفته شده است: }
$$

DassignedRole $\left(s, t_{c}\right)=\left\{r \in\right.$ roles $\mid \exists s^{\prime} \in$ staff, $\exists r \in$ roles, $\exists \mathrm{tm} \in$ teams, (s', s, r, tm, startTime, endTime) $\in$ delegates $\Lambda$ ( startTime $\leq t_{c} \leq$ endTime $\left.)\right\}$

هم:جنين تيمهايى كه يك عامل بيمارستانى در زمان

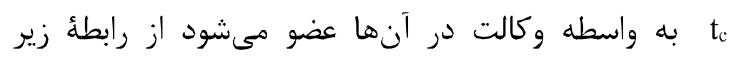
بهدست مى آيد: 


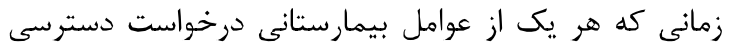

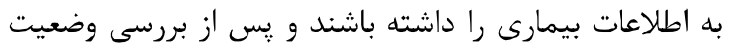

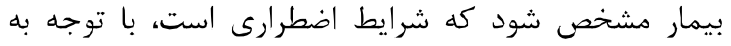

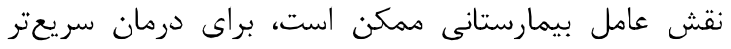

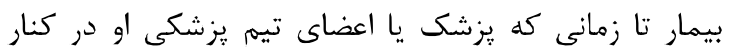

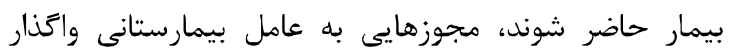
شود كه در وضعيت عادى آنها را نداشته است.

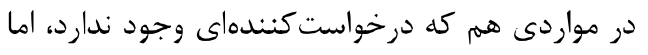

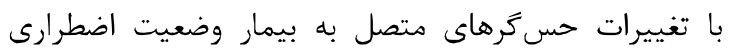

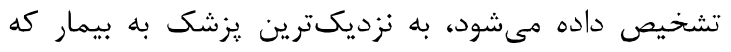

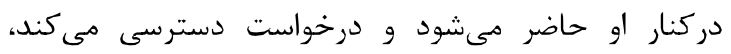

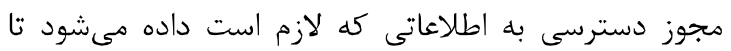

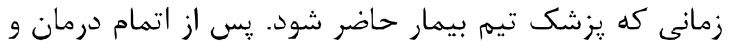
بازتشت بيمار به وضعيت عادى، تمام مجوزهايى كه دئ در اين

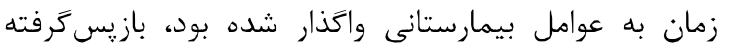
مىشود. در هر حال جون در شرايط اضطرارى موضوع

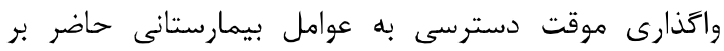
بالين بيمار (كه لزوماً عضو تيم يزشكى نئ نيستند) مطرح است؛

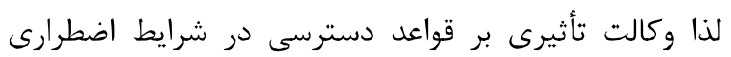

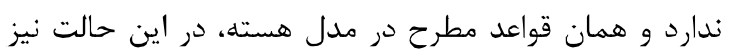

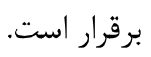

\section{$\operatorname{TbDAC}_{3}$ مد-F}

اين مدل تركيبى از دو مدل كنترل دسترسى حافظ حرد حريم

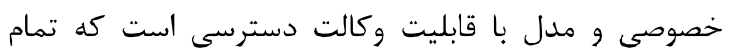
مؤلفهها و روابط را براى اعمال كنترل دسترسى در دراليت نظر

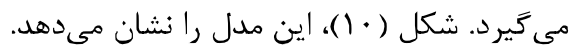

\section{ف}

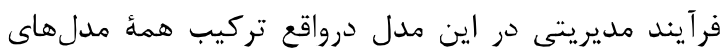

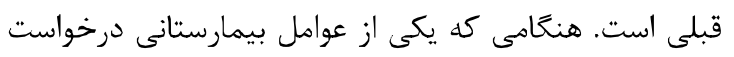

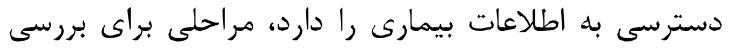
اين درخواست توسط واحد تصميمَيرندة دسترسى (PDP)

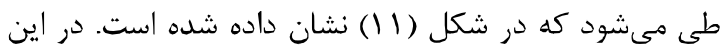
فرآيند شرايط اضطرارى هم در نظر كرفته شئ شده است.

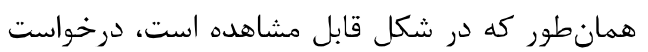

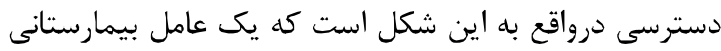

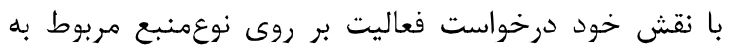
يك بيمار را با هدف دسترسى خاصى دارد.

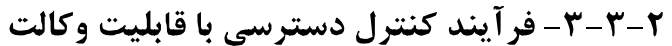

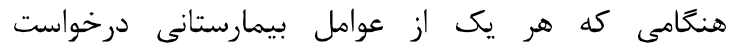

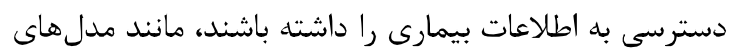

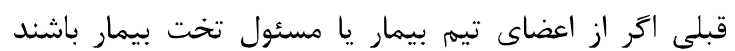
مىتوانند به اطلاعاتش دسترسى داشته باشند. تنها تفاوتى

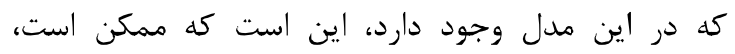

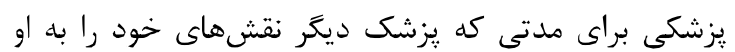

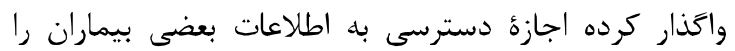

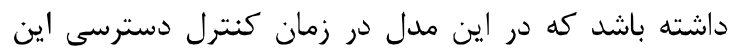
تغييرات در يايكاه دانش امنيتى با توجه به برايكاه قواعد

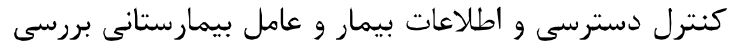

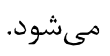

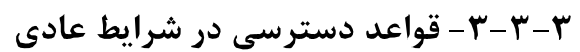

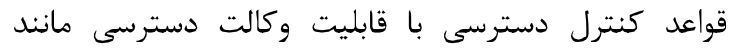

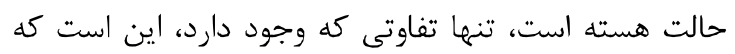

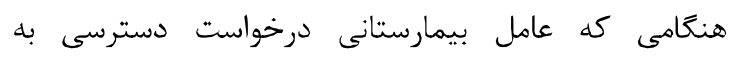

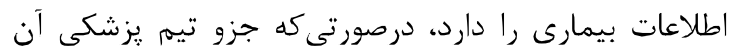

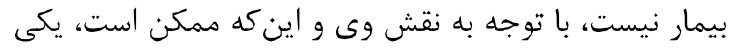

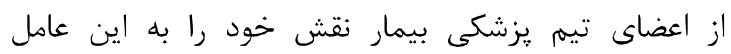

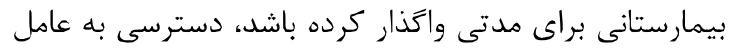

$$
\text { بيمارستانى داده مى شود. }
$$

• قاعدة دسترسى در بخش اورزانس:

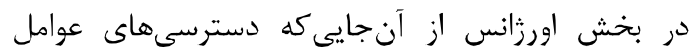
بيمارستانى براساس نوبت كارى و مجموعه تختهايى إنى إنى

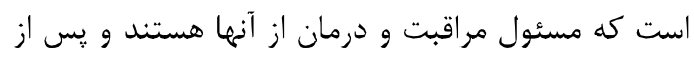

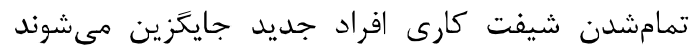

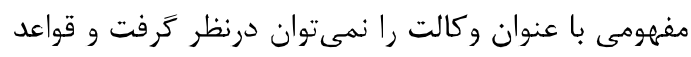
دسترسى بهطوردقيق مانند همين حالت در مدل هسته

\section{• معريف قاعدهُ دسترسى در بخشهاى اصلى:}

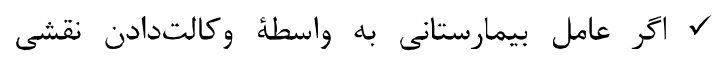

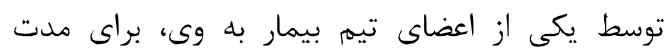

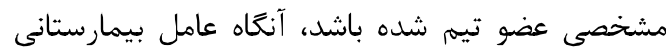

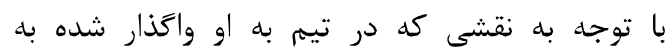

$$
\text { اطلاعات بيمار دسترسى خواهد داشت: }
$$

Delegate ( s', s, r, tm, startTime, endTime) $\wedge$ Membership $\left(s^{\prime}\right.$, tm,$\left.r\right) \wedge$ Current Time $(\mathrm{t}) \wedge \operatorname{TimcTask}\left(\mathrm{s}, \mathrm{t}_{1}, \mathrm{t}_{2}\right) \wedge\left(\mathrm{t}_{1} \leq \mathrm{t} \leq \mathrm{t}_{2}\right) \wedge$ HasTeam ( $\mathrm{p}, \mathrm{tm}) \wedge$ IsOwnedBy $($ res, $\mathrm{p}) \wedge$ Type( res, res-Type) $\wedge$ AssignedPermission ( $r$, a, res-Type $) \rightarrow$ CanAccess ( $\mathrm{s}, \mathrm{a}, \mathrm{res})$ 
درغير اينصورت بررسى مىشود عامل بيمارستانى با اين

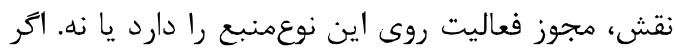

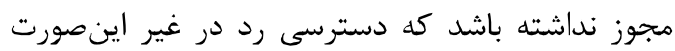

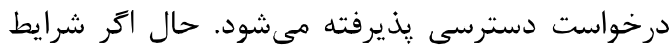

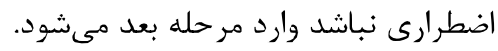

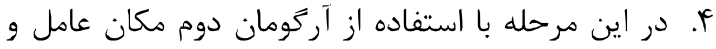

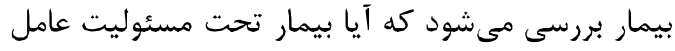
بيمارستانى است يا خير اكر عامل بيمارستانى مسئول

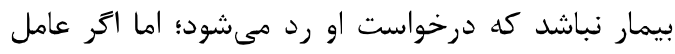

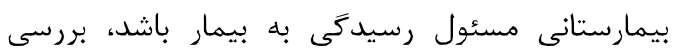

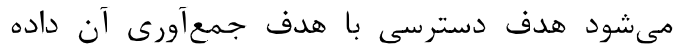
(فعاليت روى نوع-منبع) سازكار است يا نه؟ همدرفنين شرايط و ترجيحات بيمار، شرايط زمانى و ساير قوانين

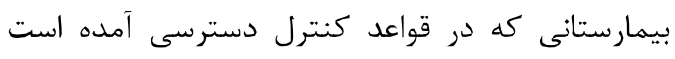

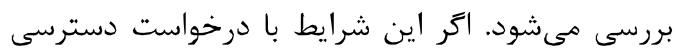

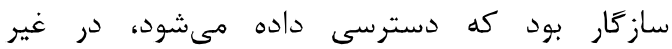
اينصورت دسترسى رد خواهد شد.
I. در نخستين مرحله بايد بررسى شود كه اينك زمان

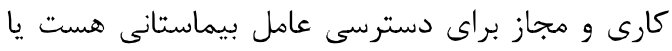

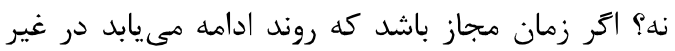
اينصورت درخواست رد مىشود.

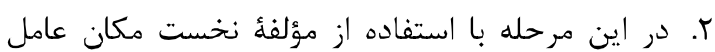

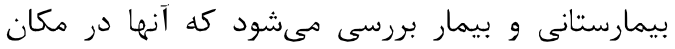

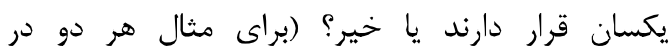
اورزانس يا هر دو در بخش يكسان) اتر يكسان نباشد دارد

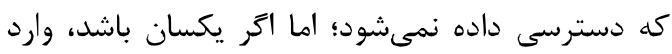
مرحلة بعد مىشود. r. در اين مرحله با استفاده از اطلاعاتى كه توسط

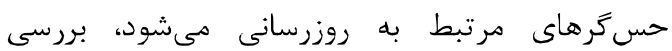
مىشود كه آيا شرايط اضطرارى است يا نه؟ اتر شرايط

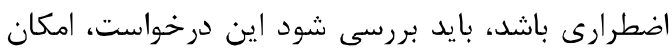

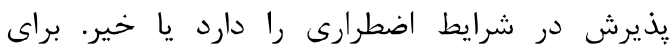

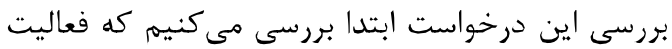

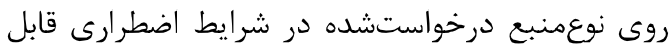

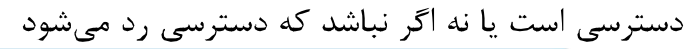

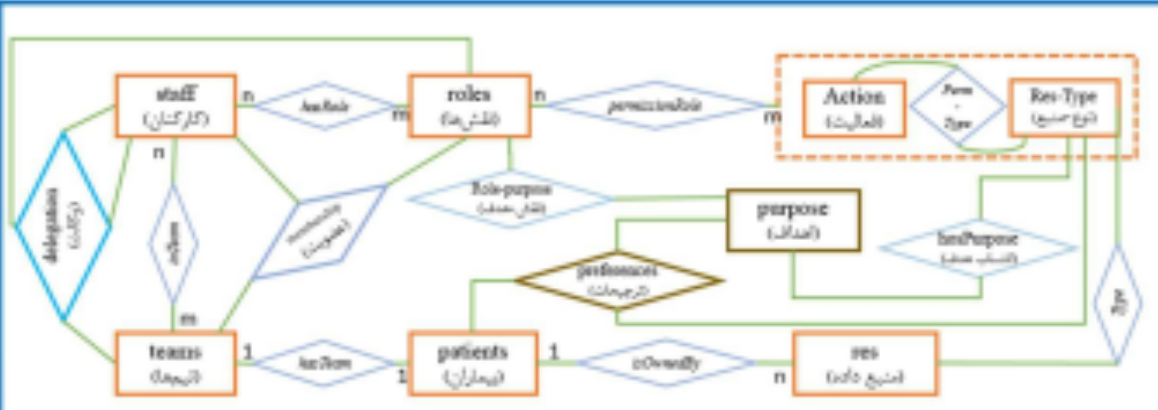

(شكل-• •): مدل دادهاى كنترل دسترسى حافظ حريمم خصوصى با قابليت وكالت دسترسى

(Figure-10): privacy protection access control data model with access delegation

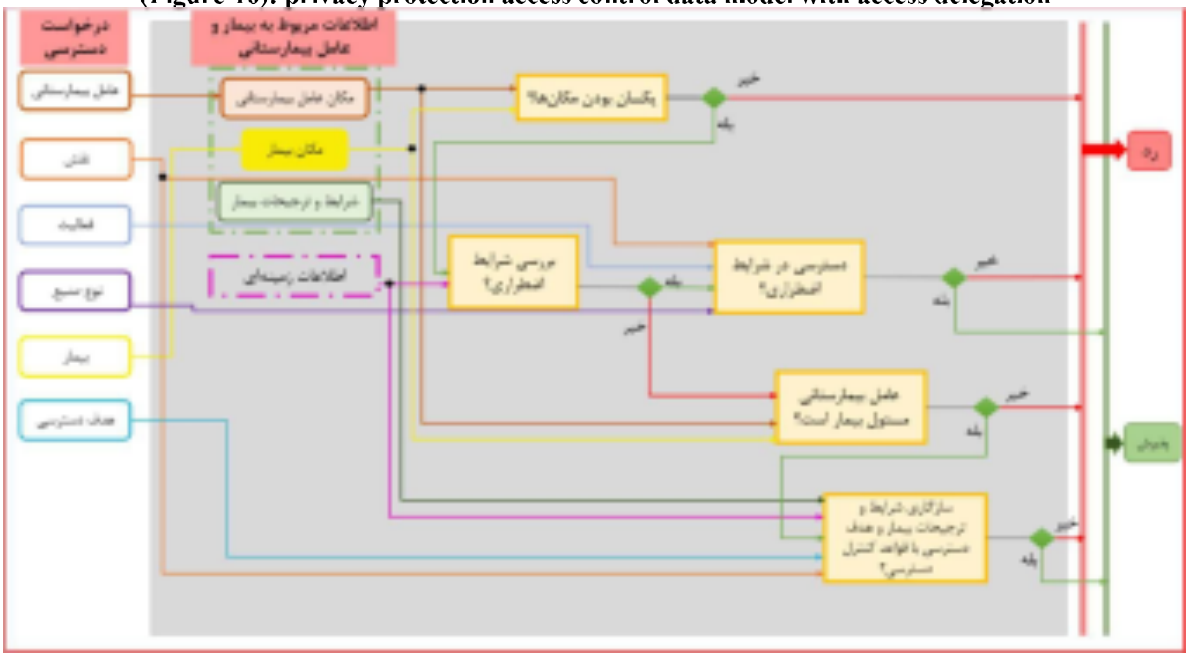

PDP شكل -11): فر آيند رسيدكى به درخواست كنترل دسترسى توسط

(Figure-11): the process of handling an access control request by PDP 
IsMemberOfTeam $(s, p) \wedge$ CurrentTime $(t)$

$\wedge \operatorname{TimeTask}\left(\mathrm{s}, \mathrm{t}_{1}, \mathrm{t}_{2}\right) \wedge\left(\mathrm{t}_{1} \leq \mathrm{t} \leq \mathrm{t}_{2}\right) \wedge$

IsOwnedBy ( res, p) $\wedge$ Type ( res, res-Type $) \wedge$

$\operatorname{HasTcam}(\mathrm{p}, \mathrm{tm}) \wedge$ Membership $(\mathrm{s}, \mathrm{tm}, \mathrm{r}) \wedge$

Role-Purpose (r, pu) $\wedge$ HospPurpose ( pu,

$\wedge$ res-Type)^ Preference ( $p$, res-Type, pu)

AssignedPermission (r, a, res-Type) $\rightarrow$

Fetch ( s, a, res, pu)

$$
\text { • قاعده واكشى خودكار در بخش اورزانس: }
$$

RFID (rfid, s) $\wedge$ AssignedRFID (p, rfid) $\wedge$

Assign (p, s) $\wedge$ IsOwncdBy $($ res, $p) \wedge$ Type $($ res, res-Type) $\wedge$ HasRole (s, r) $\wedge$ Role-Purpose (r, pu)

$\wedge$ HospPurpose $(\mathrm{pu}$, res-Type $) \wedge \operatorname{Preference}(\mathrm{p}$, res-Type, pu) $\wedge$ CurrentTime $(\mathrm{t}) \wedge$ TimeTask $\left(\mathrm{s}, \mathrm{t}_{1}, \mathrm{t}_{2}\right) \wedge\left(\mathrm{t}_{1} \leq \mathrm{t} \leq \mathrm{t}_{2}\right) \wedge$ AssignedPermission $(\mathrm{r}, \mathrm{a}, \mathrm{res}-\mathrm{Typc}) \rightarrow \operatorname{Fetch}(\mathrm{s}, \mathrm{a}, \mathrm{rcs}, \mathrm{pu})$

كفتنى است كة استنتاج امكان واكثى به معناى

استنتاج امكان دسترسى نيز هست و لذا بلهورت كلى قاعدة

$$
\text { زير نيز برقرار است: }
$$

Fetch (s, a, res, pu) $\rightarrow$ CanAccessP (s, a, res, pu)

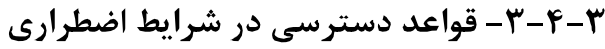
شرايط اضطرارى در اين مدل كنترل دسترسى تركيبى از دو

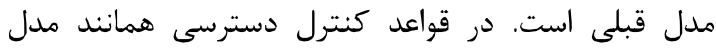
كنترل دسترسى با قابليت وكالت دسترسى، وكالت در فرآ ديند

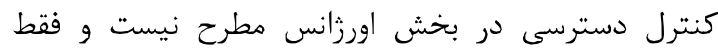
قسمت حافظ حريم خصوصىبودن در بخش اورزانس اعمال مىشود؛ اما در بخشهاى اصلى بايد در نظر داشت كه عامل

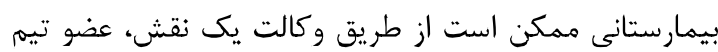

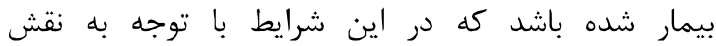

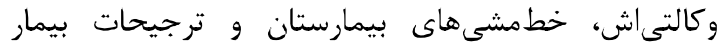

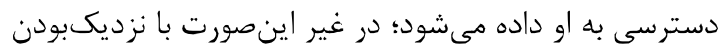
عامل بيمارستانى به بيمار و نقش عامل، دسترسى وى تعيين مىشود. • معريف قاعدة دسترسى بخش در اورزانس: ل اگر بيمار روى تختى بسترى و شرايط بيمار اضطرارى

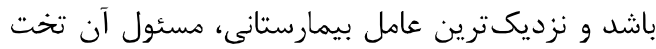

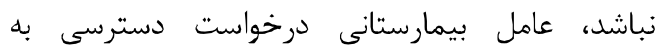
اطلاعات بيمار را مىدهد و با توجه به نقشى كه دارد، هدف دسترسى اضطرارى او به اطلاعات بيمار، نزديكى

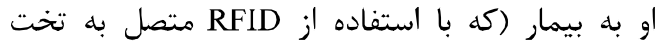

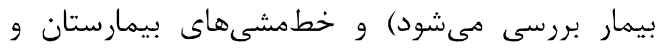

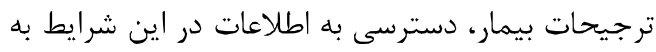

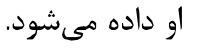

قواعد كنترل دسترسى حافظ حريم خصوصى با قابليت وكالت دسترسى از تركيب دو قاعده قبلى حاصل شده است.

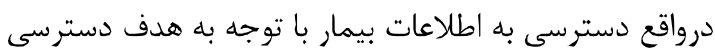
عامل بيمارستانى به اطلاعات، خطمشىهاى بيمارستان،

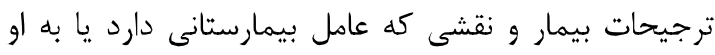

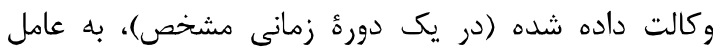

$$
\text { بيمارستانى داده مىشود. }
$$

• قاعدهُ دسترسى در بخش اورزانس:

ل اخر عامل بيمارستانى مسئول يك بيمار باشد با توجه به

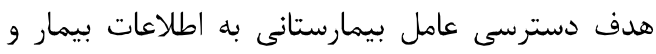

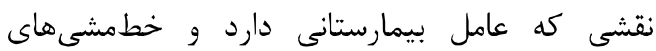
بيمارستان و ترجيحات بيمار، دسترسى به اطلاعات

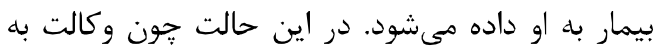
شكلى كه ما تعريف كرديم، قابل تعريف نيست، قاعده دهو داده

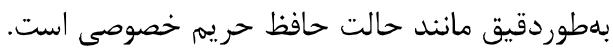
• تعريف قاعدهُ دسترسى در بخشهاى اصلى: ل اءر عامل بيمارستانى در تيم يزشكى بيمار حضور

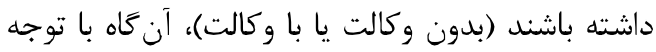
به هدف دسترسى عامل بيمارستانى به اطلاعات بيمار، نقشى كه در آن تيم دارد (يا به او وكالت داده شده)، خطمشىهاى بيمارستان و ترجيحات بيمار، امكان دسترسى وى بd اطلاعات بيمار مشخص خواهد شد.

$\operatorname{IsMemberOfTeam}(\mathrm{s}, \mathrm{p}) \wedge \operatorname{IsOwnedBy}(\mathrm{res}, \mathrm{p}) \wedge(\mathrm{I} \omega)$

Type(res, res-Type) $\wedge$ HasTeam $(p$, tm $) \wedge$

Membership (s, tm, r) $\wedge$ Role-Purpose $(r, p u) \wedge$ HospPurpose (pu, res-Type) $\wedge$ Preference $(\mathrm{p}$, resType, pu) $\wedge$ CurrentTime $(\mathrm{t}) \wedge \operatorname{TimeTask}\left(\mathrm{s}, \mathrm{t}_{1}, \mathrm{t}_{2}\right)$ $\wedge\left(\mathrm{t}_{1} \leq \mathrm{t} \leq \mathrm{t}_{2}\right) \wedge$ AssignedPermission ( $\mathrm{r}$, a, resType) $\rightarrow$ CanAccessP (s, a, res, pu)

ل بلهصورت كلى اكر عامل بيمارستانى نزديك به بيمارى

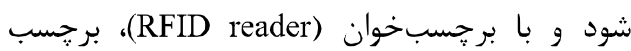
RFID كه بيمار و عامل بيمارستانى در يك تيم باشند يا بيمار به عامل موردنظر منتسب شده باشد با توجه به نقش عامل در تيم بيمار، خطمشىهاى بيمارستانى و

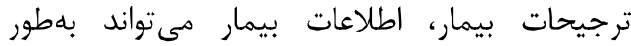
خودكار واكشى شده و در اختيار عادل بيمارستانى قرار مى • قاعده واكشى خودكار در بخش هاى اصلى: 
- تعريف نوعمنبعها (Res-Type)، آعمال (Action) و

نوعجوزها (Perm-Type).

- تعريف نقشها (roles) و انتساب نوعمجوزها به نقشها

.(permissionRole)

- تعريف كاركنان (staff) و انتساب نقشهاى هجاز به آنها

(hasRole)

$$
\text { همين قالب صورت مي يذيرد. }
$$

- تعريف مجموعه اهداف دسترسى ممكن (purpose).

- تعيين حيطه مديريتى مديران امنيتى بخشها با استفاده

از تابع canAssign كه باصصورت زير تعريف مىشود: canAssign : staff $\rightarrow 2^{\text {staff }}$

اين تابع مشخص مى كند كه يك فرد (كه داراى نقش مدير

امنيتى بخش است)، حق مديريت بر روى جه كاركنانى را دارد. اين حق مديريت، امكان انتساب نقش را به كاركنان

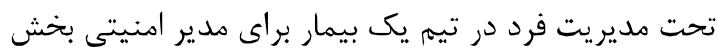
فراهم مى كند. كفتنى است كه در تعريف بالا اين محدوديت

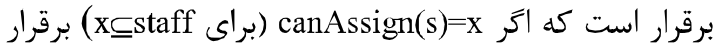

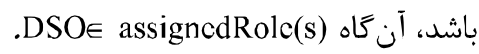
تعريف قواعد توصيفكنندهُ شرايط اضطرارى و قواعد دسترسى بر اساس قوانين و مقررات بيمارستانى. البته اين قواعد در بيمارستانها تاحد زيادى به يكديگر شباهت دارند و لذا درعمل اين قواعد، ازييشتعريفشده و ثابت هستند؛ امّا جهت افزايش انعطافيذيرى مدل، اختيار تغيير در اين قواعد براى مدير ارشد امنيتى در نظر گرفته

مدير امنيتى بخش (DSO): با ورود هر بيمار لازم است

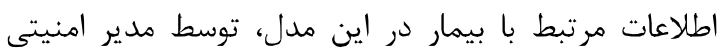

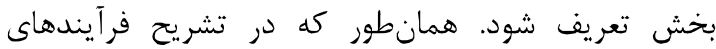
بيمارستانى در اين مقاله آمده است، نقش مدير امنيتى هر بخش در بيمارستانها عموما به سريرستار آن بخش واكذار

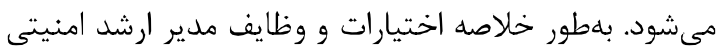

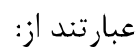

- ثبت اطلاعات بيمار (Patient) و ترجيحات حريم خصوصى وى (preferences) - تعريف تيم زيزشكى بيمار (hasTcam) و تعريف اعضاى تيم يزشكى (inTeam).

- تعيين نقش عوامل بيمارستانى در تيم يزشكى بيمار (membership)

$$
\text { canAssign }
$$

PRequest(s, a, res, pu) $\wedge$ CurrentTime $(\mathrm{t}) \wedge$

TimeTask $\left(\mathrm{s}, \mathrm{t}_{1}, \mathrm{t}_{2}\right) \wedge\left(\mathrm{t}_{1} \leq \mathrm{t} \leq \mathrm{t}_{2}\right) \wedge \operatorname{IsOwnedBy}($ res, p) $\wedge$ Type $($ res, res-Type $) \wedge$ RFID (rfid, s) $\wedge$ AssignedRFID $(p$, rfid $) \wedge$ IsEmergency $(p) \wedge$ HasRole (s, r) $\wedge$ Role-Purpose $(r, p u) \wedge$ HospPurpose $(\mathrm{pu}$, res-Type $) \wedge \operatorname{Preference}(\mathrm{p}$, res-Type, $\mathrm{pu}) \wedge$ AssignedPermission (r, a, res-Type) $\rightarrow$ CanAccessP(s, a, res, pu)

\section{• تعريف قاعدهُ دسترسى در بخشهاى اصلى:}

ل اگر عامل بيمارستانى و بيمار در يك تيم يزشكى

نباشند و نقشى از آن تيم هم به عامل وكالت داده نشده

باشد، با توجه به نزديكى عامل بيمارستانى به بيمار،

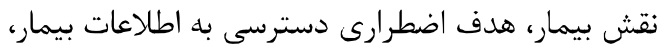

خطمشىهاى بيمارستان و ترجيحات كاربر، دسترسى

$$
\text { به عامل بيمارستانى داده مىشود: }
$$

PRequest $(\mathrm{s}, \mathrm{a}, \mathrm{res}, \mathrm{pu}) \wedge$ CurrentTime $(\mathrm{t}) \wedge$

TimeTask $\left(\mathrm{s}, \mathrm{t}_{1}, \mathrm{t}_{2}\right) \wedge\left(\mathrm{t}_{1} \leq \mathrm{t} \leq \mathrm{t}_{2}\right) \wedge$ IsOwnedBy(res, p) $\wedge$ Type $($ res, res-Type $) \wedge \operatorname{RFID}($ rfid, s $) \wedge$ AssignedRFID(p, rfid) $\wedge \operatorname{IsEmergency}(p) \wedge$ HasRole $(s, r) \wedge$ Role-Purpose $(r, p u) \wedge$

HospPurpose (pu, res-Type) $\wedge$ Preference $(p$, resType, pu) $\wedge$ AssignedPermission(r, a, res-Type) $\rightarrow$ CanAccessP(s, a, res, pu)

\section{Q-}

در توصيف خانواده مدل كنترل دسترسى TbDAC، با تشريح كامل فرآيندهاى بيمارستانى و كنترل دسترسى، بهطور ضمنى به نحوه مديريت كنترل دسترسى نيز تا حد زيادى اشاره شد. در ادامه بهطور مشخص نحوه مديريت كنترل دسترسى و نحوه درج اطلاعات موردنياز در كنترل

$$
\text { دسترسى مورد تشريح قرار مى }
$$

در مدل يبشنهادى دو نقش مديريتى براى مديريت

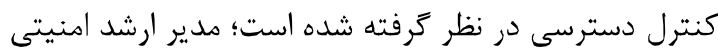
(كه در كل سيستم يك نفر است) و مدير امنيتى بخش (كه در سيستم بيمارستانى بdطورمعمول همان سريرستار بخش

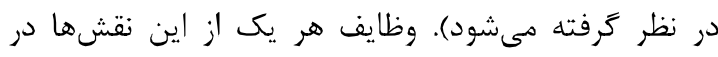
مديريت كنترل دسترسى به شرح زير است. مدير ارشد امنيتى (SU): مدير ارشد امنيتى در نصب و راهاندازى اوليه سامانه كنترل دسترسى مشخص مىشود و بيشترين اختيارات مديريت امنيت را دارد. ضمن آنكه حيطه مديريتى مديران امنيتى بخشها نيز توسط مدير

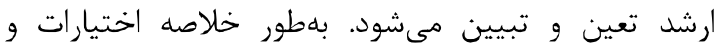
وظايف مدير ارشد امنيتى عبارتند از: 
محيط مورد نظر را مورد ارزيابى قرار داد. آزمون توانمندى

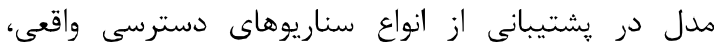

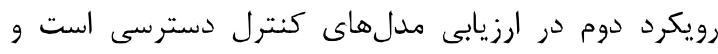

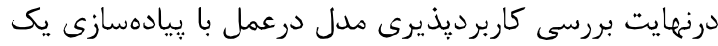

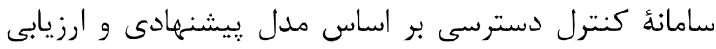

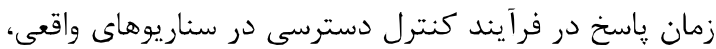
رويكرد سوم در ارزيابى مدل ييشنهادى است. در ادامه اين داين

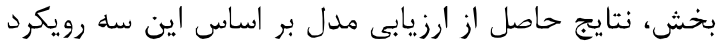
ارايه شده است.

- تعريف و حذف وكالت دسترسى (delegation) پيس از طى فرآيند توصيفشده جهت اعطاى وكالت و تأييد رييس

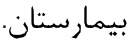

\section{F - ارزيابى و مطالعه موردى} مدل ارايهشده از جند ديدكاه مورد ارزيابى قرار كرفته شده

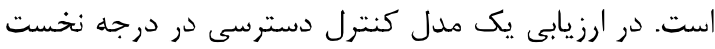

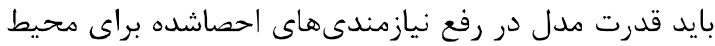

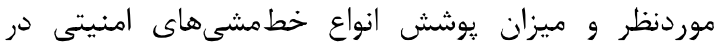

(جدول-Y): ارزيابى كيفى مدل كنترل دسترسى بيشنهادى در قياس با مدلهاى مشابه در سلامت الكترونيكى

(Table-2): Evaluation of the proposed access control model in comparison with related models in e-health

\begin{tabular}{|c|c|c|c|c|c|c|}
\hline خصافظ حريم & انعطاف يذيرى & دسترسى اضطرارى & دسترسى وكالت & آكاه از محيط & مدل استفاده شده & قابليتهاى مدل \\
\hline$x$ & $x$ & $\times$ & $\times$ & $\checkmark$ & تر كيب RBAC و RMAC & جرجيديس و همكاران [16] \\
\hline$x$ & $\checkmark$ & $x$ & $\checkmark$ & $\checkmark$ & TBAC & نرايانان [23] \\
\hline$\checkmark$ & $\times$ & $\checkmark$ & $\times$ & $\checkmark$ & STEM-RBAC & جور جيكاكيس [18] \\
\hline$\checkmark$ & $x$ & $\times$ & $\times$ & $\times$ & P-RBAC & نى و همكاران [19] \\
\hline$\checkmark$ & $x$ & $x$ & $x$ & $\times$ & PBAC & يانگ و همكاران |20| \\
\hline$\checkmark$ & $\checkmark$ & $x$ & $x$ & $x$ & MPP- $\triangle \mathrm{B} \Lambda \mathrm{C}$ & سيكورانزا و همكارش [8] \\
\hline$\times$ & $\checkmark$ & $\checkmark$ & $\times$ & $\checkmark$ & RBAC, MAC تركيب & تو يه و همكارش [22] \\
\hline$\times$ & $\checkmark$ & $\checkmark$ & $\checkmark$ & $\checkmark$ & تركيب RBAC و DAC & خن و همكارش |13| \\
\hline$\checkmark$ & $\checkmark$ & $\checkmark$ & $\checkmark$ & $\checkmark$ & 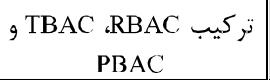 & مدل بيشنهادى TbDAC \\
\hline
\end{tabular}

به عامل، بر اساس منابع اطلاعاتى مرتبط با بيمار موردنظر، بهصورت هجموعهاي از هجوزها عينيت مى ئيابد.

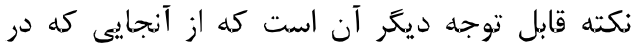

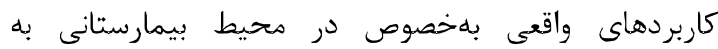

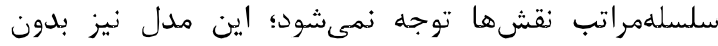

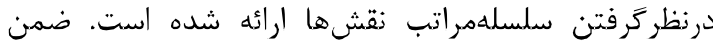

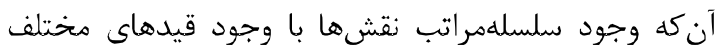

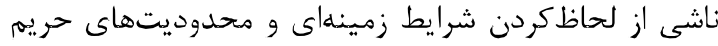

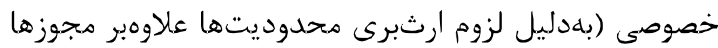

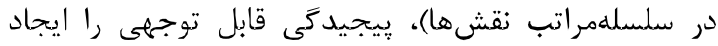

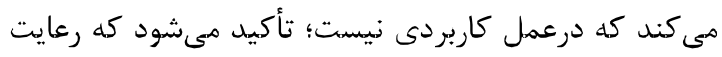

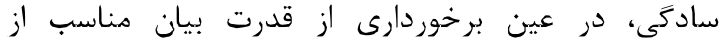

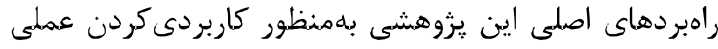
اين مدل در كاربرد اينترنت اشيا در سلاهت الكترونيكى بودهد و لذا ارايه يك مدل قدر تمند ولى بيجيده هدنظر نبوده است. كفتتى است كه با درنظركرفتن زمان و مكان بيمار و و عامل بيمارستانى و همجنين اطلاعات حياتى بدن بيمار براى

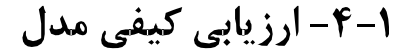

ارزيابى كيفى مدل در قياس با مدلهاى مشابه ارايهشده در إردي جدول (T) ارايه شده است. همانطوركه در اين جدول آمده، مدل ارايهشده بهكونهاى طراحى شده است كه نيازمندهاى

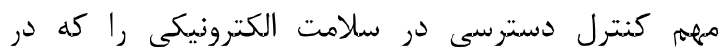
مدل هاى مشابه ديكر يوشش داده نشده بود، ارضا كند. يكى از نكاتى كه در نگاه زخست درخصوص اين مدل قابل طرح است، رابطه آن با مدلهاى كلاسيك نقشمبنا

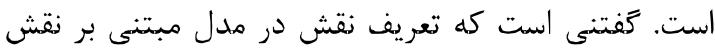
(RBAC) مدل RBAC

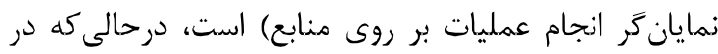

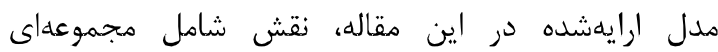

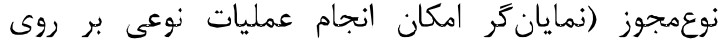
نوعمنابع) است و فقط يس از عضويت يك عامل در تيمه

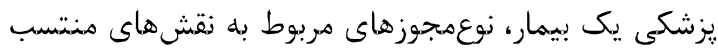


- hasRole $=\{($ ahmadi, Nurse $)$, (salami, Doctor $)$, (salami, General practitioner), (tahami, heart specialist Doctor) $\}$

- role-Purpose $=\{($ Nurse, treatment $)$, (Doctor, Emergency), (Gencral practitioner, Emergency), (heart specialist Doctor, treatment)

- hasTeam $=\{$ (vahidi, Team 3$)\}$

- assignedPermission $=\{($ Nurse, Read, Test $),($ Doctor, Read, I/O Sensor), (heart specialist Doctor, Read, Test), (General practitioner, Read, Test)\} hospPurpose $=\{($ Treatment, Test $),($ Emergency , I/O Sensor), (Emergency, Test)

- preferences $=\{$ (alavi, Test, Treatment $),($ fathi, I/O Sensor, Emergency), (vahidi, Test, Treatment), (vahidi, Test, Emergency)\}

\section{سناريوى نخست:}

عامل بيمارستانى، احمدى يك زيرستار است و در بخش اورزانس بيمارستان خدمت مى كند؛ مجموعه تختهايى كه

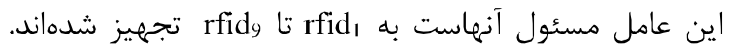
ساعت كارى احمدى از ساعت V تا ها لا است. بيمارى بـ نام علوى در بخش اورثانس و روى تختى با rfid احمدى درخواست دسترسى به نتايج آزمايش علوى را با

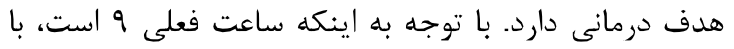

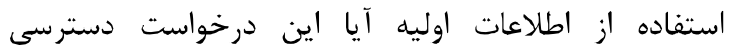
يذيرفته مىشود يا خير؟

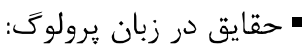

ataff (ahmadi).

patient (alari).

haspole (ahadad, Eurse).

role_Purpose inurse, treatment!

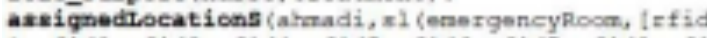

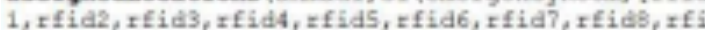
(19) ))

assignedtocationp (alavi, D1 (energencyRocn, rfidz)

).

iacwnedey (text alari lecord, alari) .

type (test alavi hecosd, test).

hosp Parpose (treatrent, test).

proference (alavi, test, treatment) ?

aseignedidernialion (nuras, read, text) .

tine rask (ahuadi, ?,15).

current Time $\langle 9\rangle$.

insabset $(p 1[\mathrm{~L}, \mathrm{Y}), \mathrm{s} 1(\mathrm{LP}, \mathrm{L})) \mathrm{z}$

$$
\text { ه قواعد كنترل دسترسى مورد نياز: }
$$

I. $=-1$ ip,

menbex $\{Y, L\}$.

assign $(P, 8):-$

pationt $(D)$,

seaft $(\mathrm{s})$,

assignediocation P (P, PL),

ansignedt.ocaticens $(\Omega, s L)$,

insubset $(01$, BL $)$.

camhecessP(8, A, Res, Pa) :-

anaign $(D, \Omega)$,

currentsire (z),

timetask $(8, \mathrm{Tz}, \mathrm{Tz})$,

$71=c z$,

$7=<-2$

i sonnedisy $(R-5, P 1$.

trpe (nex, Rex_trpe),

haskole $\mid 8, \mathrm{~B})$.

rolo Purpose (R, Pa) .

hoapDurpose (Du, Des_type),

preforenoe $\langle$ D, Ples tripe, Fui,

sssignedPernission \{R, R, Res typel.

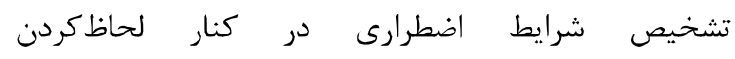
محدوديتهاى مرتبط با حفظ حريمم خصوصى بيمار در فرآيند كنترل دسترسى، مىتوان كفت كه اين هدل بهلحاظ مفرديط

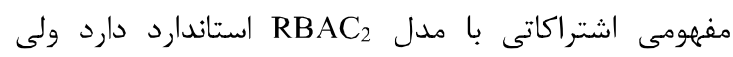
بهدليل تفاوت مدل ييشنهادى با مدل مBAC2 در مفهوم

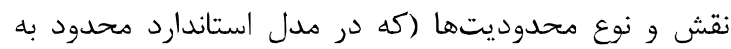

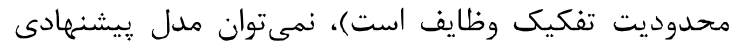

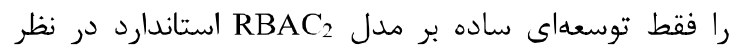
كرفت. توجه كنيد كه تركيب مفهوم نقش با مفهوم تيم در

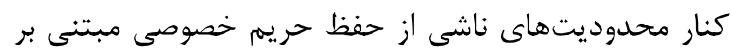

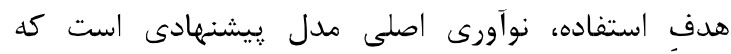

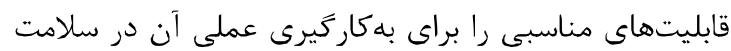
الكترونيكى به همراه داشته است.

\section{r-F- T- آزمون مدل بر اساس سناريوهاى

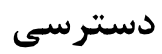

براى اين كه كاربرد مدل كنترل دسترسى ارائهشده در محيط سلامت الكترونيكى سنجيده شود، لازم است، قواعد كنترل

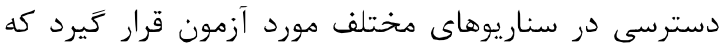

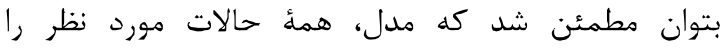

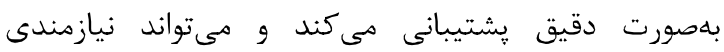

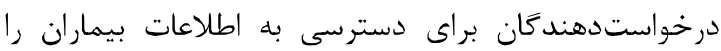

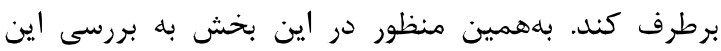

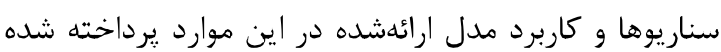
است. كفتنى است كه اين سناريوها بر اساس قواعد كنترل دسترسى مدل TbDAC اين سناريوها در زبان يرولوى با استفاده از ابزار مربوطه مورد بررسى قرار كرفته است.

اين سناريوها بر اساس اطلاعات مربوط به يك بيه بيمارستان است كه مؤلفههاى آن در زير فهرست شده بره است:

- staff $=\{$ ahmadi, salami, tahami, amiri, javadi $\}$

- roles $=\{$ Nurse, Doctor, heart specialist Doctor, General practitioner ?

- patients $=\{$ alavi, fathi, vahidi $\}$

- locations $=\{$ emergencyRoom, heartSection $\}$

- teams $=\{$ team 3$\}$

- res-Type $=\{$ Test, I/O Sensor $\}$

- res $=\{$ Test alavi's Recored, Sensor fathi's Recored, Test vahidi's Recored $\}$

- actions $=\{$ read $\}$

- assignedLocation $\mathrm{P}=\{($ alavi, (emergencyRoom, rfid2)), (fathi, (emergencyRoom, rfid12)) \}

- assignedLocationS $=\{$ (ahmadi, (emergencyRoom, \{rfid1,..., rfid9\})), (salami, (emergencyRoom, $\{$ rfid1, rfid2, .., rfid10 $))\}$ 
canaccessp ( $3, \mathrm{~A}$, Bes, Duj :-

pRequest $(8, \lambda$, Res, Pu) ,

currentTine (T),

tineTask $(3, \mathrm{~T} 1,72)$,

$T 1=<\mathrm{T}$,

$\mathrm{T}=<\mathrm{r} 2$,

is Ownedidy (Res, P),

type (Res, Res_type),

rfid(RFID, 8),

assignedRFID (P, RFID),

isEnergency (P),

haskole $(3, \mathrm{R})$,

role_Durpose (R, Du) ,

hospPurpose (Pu, Res_type),

preference (P, Res type, Pu\},

assignedpernission (R, $\mathrm{A}$, les_type) .

با استفاده از حقايق بالا و قواعد كنترل دسترسى در اورزانس در شرايط اضطرارى رابطه (f)،، استنتاج مىشود كه اطلاعات دريافتى از حسكرهاى متصل به فتحى مى تواند با هدف اضطرارى در اختيار سلامى قرار كيرد. P. canfoccessP(salami, read sensor_fathi_Record, emergency) true.

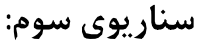

عامل بيمارستانى تهامى با نقش يزشك متخصص قلب در يكى از بخشهاى اصلى بيمارستان حضور دارد. تيم يزشكى

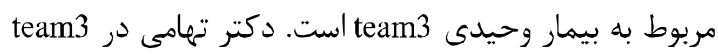
عضو بوده و نقش يزشك متخصص را در اين تيم دارد. دكتر

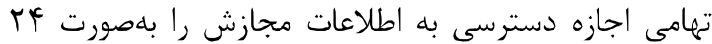
ساعته دارد. اگر دكتر تهامى درخواست دسترسى به نتايج آزمايشهاى وحيدى را با هدف درمانى داشته باشد، با توجه به اينكه ساعت فعلى 11 است، با استفاده از اطلاعات اوليه

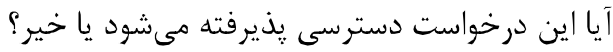

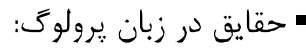

staff (tahami) ,

pationt (vahidi) .

hasTeam (vahidi, tean 3).

manberahip (tahami, tean 3, heart_specialist_ Doctor).

role_purpose thesrt_specialist_Doctor, tres tment).

isounedBy (test_vahidi_Record, vahidi).

type (test_vahidi Record, test) ,

hosplurposo (treatrent, test) .

preference (vahidi, test, treatment) .

assignedPermission (hesrt_specialist_Docto

${ }_{\text {, read, test) . }}$.

tineTask (tahasi, 0,24$)$.

currentFine (11).
با استفاده از حقايق بالا و قواعد كنترل دسترسى در بخش

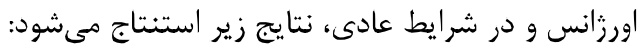
طبق مسند InSubset رابطه (1) از آنجايیىكة مكان علوى و احمدى يكسان است و rfid منتسب به علوى عضو مجموعأ نظر احمدى قرار مى گيرد (رابطه ب).

InSubset((emergencyRoom, rfid $\left._{2}\right)$,

(emergencyRoom, $\left.\left\{\mathrm{rfid}_{1}, \mathrm{rfid}_{2}, \ldots, \mathrm{rfid}_{9}\right\}\right)$ )

Assign(alavi, ahmadi)

با توجه به اطلاعات موجود و قاعده دسترسى رابطه (r)

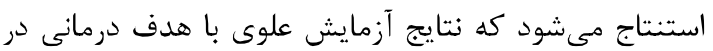
اختيار احمدى قرار مى خيرد. ?- canAccess:P(ahmadiread test alavi Record treatment). true.

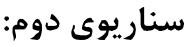

عامل بيمارستانى سلامى با نقش يزشك در درون بخش اورزانس

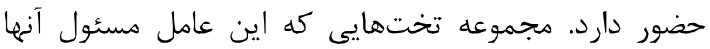

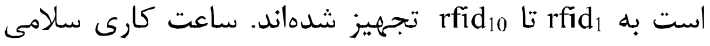

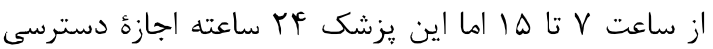

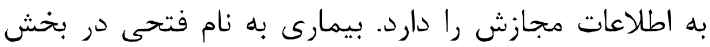

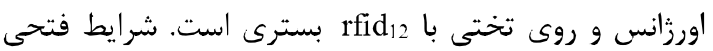
اضطرارى است. سلامى درخواست دسترسى به اطلاعات حسكرهاى متصل به فتحى را با هدف درمانى (در شرايط

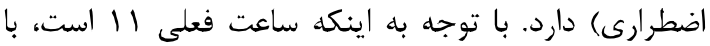

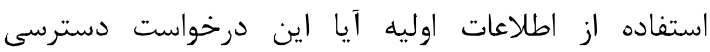
يذيرفته مىشود يا خير؟

فرض كنيد كه با توجه به اطلاعات دريافتى از حسگرهاى متصل به بيمار شامل فشار خون (زير V) و ضربه بان

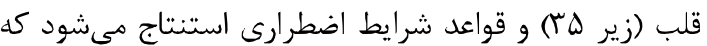

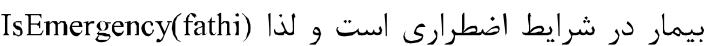
برقرار است. با اين اوصاف بر اساس اطلاعات موجود، حقايق زير در هايعاه دانش امنيتى برقرار است:

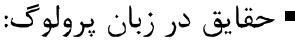

staff isaland) :

patient |futhi|

rfidirefidia, eaisis.

anigredorro itathi, rfidaz?

rasoole (salash, sooter).

role. Durpose [doctor, onergency].

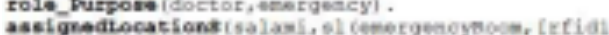

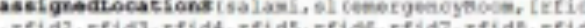
Tridaphy imigredlocation (fath1, pl (eosergencyhocen, rfldiz)

1. Inownediry (wankor_fath__koord, fathi). isknetgeney (tathi)

type (sensor_tathi_kecord, 1/o_anesox).

hospourpose (emergency, i/o_Senuor]

preferance ifachs, 1/o_zensor, tuergency]

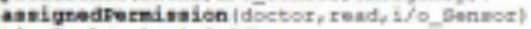

tiastakk (saland, 0,24$)$.

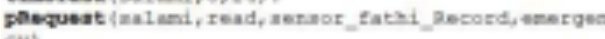
(c)

currentrime(12). 
staff (tahani)

staff (anici) ,

pationt (vahidi) .

delegate (tahami, amiri, heart specialist Do

ctor, $\operatorname{team} 3$, date $\{97,5,30\}$, dat $\bar{t} \in(97,6,6)\}$.

hasTean (vahidi, toam 3).

haselele (tahami, beart_opecialist_Doctor) ,

isownedBy (test_rahidi_Record, vahidi).

type (test vahidi Record, test).

roleburpose (heart__epecialist_Doctor, treat

mont).

hospparpose (treatment, test) .

preference [vahidi, test, treatnent]

assignedPernission (heart_specialist_Docto

Y, read, cest).

currentDate (date $\{97,6,4)\}$,

currentsime $(12)$.

tineTask (ani $r 1,0,24)$.

• قواعد كنترل دسترسى مورد نياز:

membership $(S, T m, R)$ :-

delegate (S2, $\mathrm{S}, \mathrm{R}, \mathrm{Tm}, \mathrm{D1}, \mathrm{D} 2)$.

iskemberorTeam $(S, P)$; -

pationt (P),

hastean $(D, T m)$,

membership $(9, \% \mathrm{~m}, \mathrm{R})$.

candccess $\mathrm{P}(\mathrm{B}, \mathrm{A}, \mathrm{Res}, \mathrm{Du})$ :-

isMemberofTean $(S, P)$,

currentrime $(T)$.

timeTask $(s, T 1, T 2)$,

$\mathrm{F} 1=<\mathrm{T}$,

F=cT2,

isownedBy $\langle$ Res, P),

type (Res, Res_type),

hastean $(D, T x)$,

membership (S, $\mathrm{Fm}, \mathrm{R})$.

rolepurpose (R, Pu),

hospDurpose (Pu, Res_type),

preference (D, Res type, Du),

assignedpermission (R, A, Res_type) .

با استفاده از حقايق بالا و قواعد كنترل دسترسى در

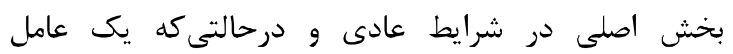

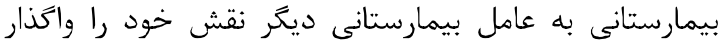
كرده، نتايج زير استنتاج مى شيود.

طبق مسند Delegate رابطه (V)، از آنجايى كه دكتر

تهامى نقش تزشك متخصص قلب را در تيم سه به دكتر اميرى واكذار كرده و تاريخ كنونى بين تاريخ شروع و وايان

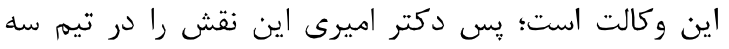
عهدهدار مىشود. همجنين از آنجايى كه اين عضويت استنتاج شد و وحيدى نيز عضو تيم سه است، يس طبق رابطه (A) نتيجه مىشود اميرى در تيم :زئشى وحئ وحيدى است.

Membership (amiri, Team 3 ,

heart specialist Doctor)

IsMemberOfTeam (amiri, vahidi)

حال با توجه به اطلاعات موجود و قاعده دسترسى رابطه (9) استنتاج مىشود كه نتايج آزمايش وحيدى با هدف درمانى در اختيار اميرى مىتواند قرار بخيرد.

$$
\text { • قواعد كنترل دسترسى مورد نياز: }
$$

isMemberofTeam $(S, P)$ :-

patient $\{P\}$,

hastean (P, Tr),

membership $(S, T \mathrm{~m}, \mathrm{R})$.

Candocess D (S, A, Res, Pu) :is Nemberorsean $(S, D)$.

is OwnedBy (Res, D),

type (Res, Res_type),

has7ean [D, Ta).

mombership $(\mathrm{S}, \mathrm{Tn}, \mathrm{B})$,

role Durpose (R, Du),

hosp Durpose (Du, Res_type),

preterence $(\mathbb{P}$, Res_type, Du $)$ '.

currentrine (T)

timezask $(8, T 1, T 2)$,

Timer,

$T=<\mathrm{r} 2$,

assignedPernission ( $R, A, R e s$ type).

با استفاده از حقايق بالا و قواعد كنترل دسترسى در بخش اصلى در شرايط عادى، نتايج زير استنتاج مىشود. طبق مسند IsMemberOfTeam رابطه (ه)، از آنجايى كه تيمم مربوط به وحيدى team3 است و دكتر تهامى نيز در اين تيمى سه نقش يزشك متخصص را دارد، يس دكتر تهامى در تيم يزشكى وحيدى است.

IsMemberOfTeam (tahami, vahidi)

با توجه به اطلاعات موجود و قاعده دسترسى رابطه (ક) استنتاج مىشود كه نتايج آزمايش وحيدى با هدف درمانى

$$
\text { در اختيار تهاهى قرار مى گيرد. }
$$

?- canAccessP(tahami, read, fest_vahidi_Record, treatment).

true.

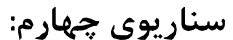

عاملهاى بيمارستانى تهامى و اميرى در يكى از بخشهاى اصلى بيمارستان حضور دارند. اطلاعات مانند سناريوى قبل است. دكتر تهامى از تاريخ • س/ه/

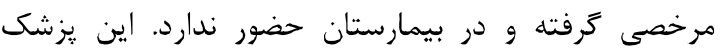
نقش خود را در team3 به دكتر اميرى وكالت داده است. با توجه به اينكه دكتر تهامى اجازه دسترسى به اطلاعات مجازش را بهصورت FF ساعته داشت، دكتر اميرى نيز اين اجازه را دارد. آر دكتر اميرى درخواست دسترسى به نتايج آزمايشهاى وحيدى را با هدف درمانى داشته باشد، با توجه

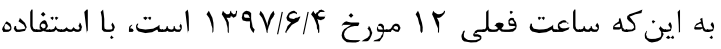
از اطلاعات اوليه آيا اين درخواست دسترسى يذيرفته

$$
\text { مىشود؟ }
$$

" حقايق در زبان يرولوك: 


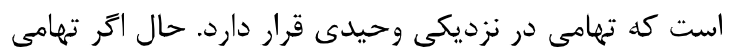

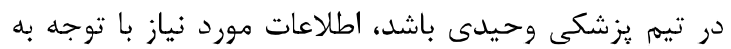

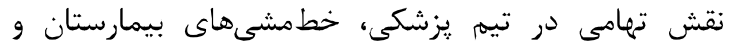

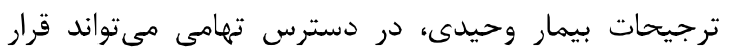
كيرد

staff (tahori) .

patient (vahidi) .

rfid (rfid45, tahami).

assignedRFID (vahidi, YRid45).

iaMomberofroam (tahami, vahidi).

has Toam (vahidi, team 3 ).

membership (tahami, team, 3, heart_specialist_ Doctor).

iscomeday (test_vahidi_Record, vahidi).

eype (test_rahidi_Recor̃d, test).

roleparpose theart specialist Doctor, treat ment).

hospluxpose (tereatment, test).

preforence (vahidi, test, treatment) .

assignedPernission (heart_specialist_Docto

$z_{\text {r read, test). }}$

timetask (tahami, 0, 24).

currentrine (13).

$$
\text { • ق قواعد كنترل دسترسى مورد نياز: }
$$

fetch $(S, A, R e s, P u)$ :-

rfid (RFID, S),

assignedRFID (D, RFID),

ismemberofTeam $(S, D)$,

currentTime (T),

timeTask $(\xi, T 1, T 2)$,

$T 1=<\mathrm{T}$,

$\mathrm{T}=<\mathrm{T} 2$,

isownedBy (Res, P),

type (Res, Res_type),

hasTeam $(P, T m)$,

membership (S, Tm, R),

rolepurpose (R, Pu),

hospPuxpose (Pu, Res_type),

preference (P, Res_type, Pu),

assignedDermission (R, A, Res_type) .

با استفاده از حقايق بالا و قواعد كنترل دسترسى در بخش إنش اصلى در شرايط عادى رابطه (1)، نتيجأ زير استنتاج

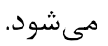

?- fetch(tahami,read,test_vahidi_Record,treatment).

true.

\section{F-F- هيادهسازى سامانه كنترل دسترسى و

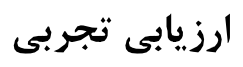

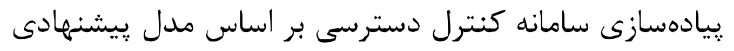

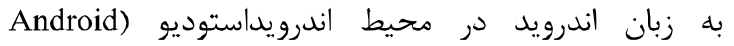
Studio

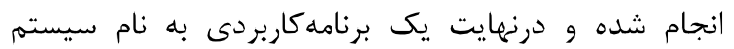
يروندة الكترونيكى سلامت بيمارستان ايجاد شده است.
7- canAccessP(amin, read,test_vahidi_Record,treatment). true.

$$
\text { سناريوى ينجم: - (عاري }
$$

عامل بيمارستانى جوادى با نقش بزشك عمومى درئ در يكى از

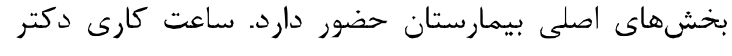

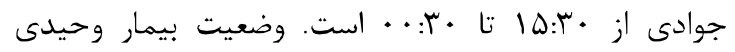

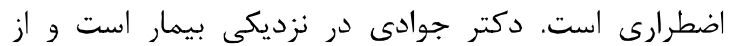
طريق RFID reader برجسب RFID منتسب به به بيمار

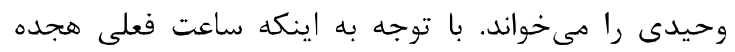

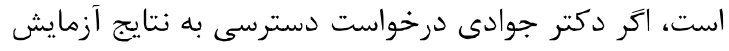
وحيدى را داشته باشد، با استفاده از اطلاعات اوليه آيا اين آناين

$$
\begin{aligned}
& \text { درخواست دسترسى يذيرفته مىشود؟ } \\
& \text { • حقايق در زبان يرولوكى: }
\end{aligned}
$$

staff (javadi).

patient (vahidi).

rrid(rfid45, javadi).

asaignedPFID (vahidi, YRid45).

iscomedBy (test_vahidi_Record, vahidi) .

type (test rahidi Becor̃d, test).

istrergeney (vahidi),

hasRole (javadi, general_practitioner) .

rolePurpose (general_practitioner, energenc

y).

hosppurpose (emergency, test).

preference (vahidi, test, ecnergency).

assignedpermission (general_practitioner, r ead, test).

plequest (jayradi, read, test_yahidi_Record,e mexgencyl -

timorask (javadi, 15, 24) .

currentTime $\langle 10\rangle$.

$$
\text { • قواعد كنترل دسترسى مورد نياز: }
$$

CanAccessP (S, A, Res, Pu) :-

pReguest (S, A, Res, Pu),

isownedBy (Res, P),

type (Res, Res_type),

Ifid (RFID, $s$ ),

assignedRFID (P, RFID),

isEmergency $(P)$,

hasRole $(S, R)$,

rolepurpose (R, Du) ,

hospPurpose (Pu, Res_type) '.

preference (P, Res_type, Pu),

currentriae $(T)$,

timeTask $(S, T 1, T 2)$,

$\mathrm{T} 1 \mathrm{~m}<\mathrm{T}$,

$\mathrm{T}=<\mathrm{T} 2$,

assignedPermission (R, A, Res_type) .

با استفاده از حقايق بالا و قواعد كنترل دسترسى در بخش

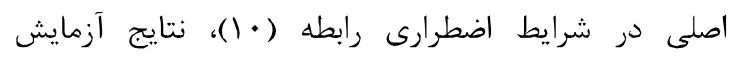

وحيدى در شرايط اضطرىى در اختيار جوادى قرار مى كيرد. P. canAccessP(javadi,read, test_vahidi_Record,emergency). true.

سناريوى ششه:

عامل بيمارستانى تهامى در بخش اصلى قرار دار دارد. اخر تهامى إنى برجسب RFID منتسب به وحيدى را بخواند به اين معنا 
به اينكه بيمار در شرايط اضطرارى باشد يا نباشد و بسته به

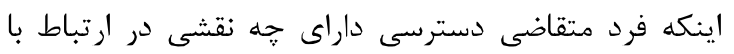

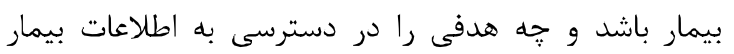

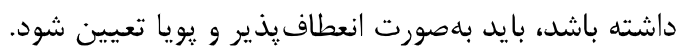

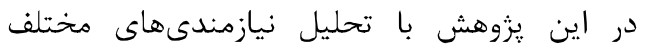

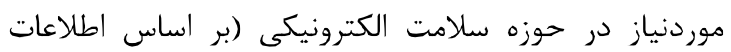

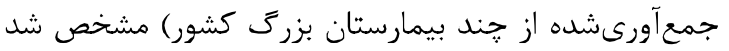

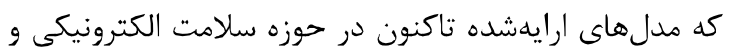

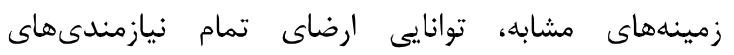
مطرحشده در كنترل دسترسى به اطلاعات بيماران رانيان را ندارند.

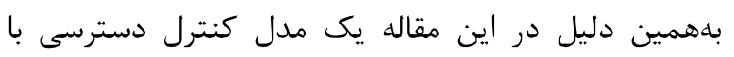

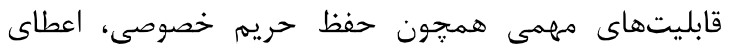

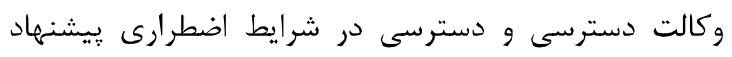

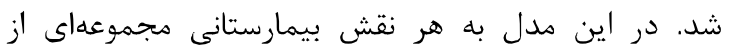

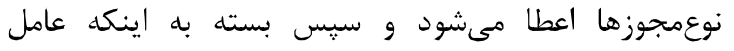

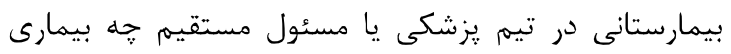

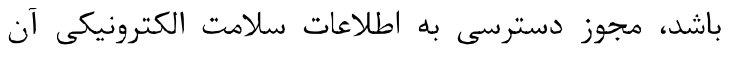

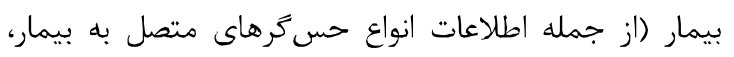

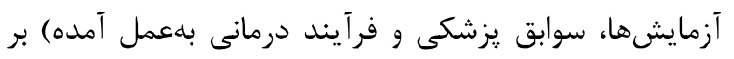

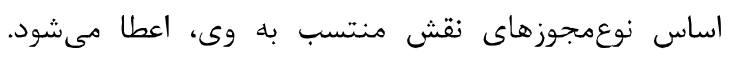
حفظ حريم خصوصى بيمار در اين مدل بر اساس ترجيحات

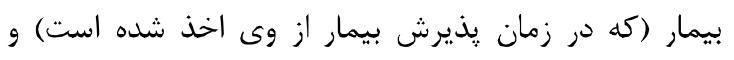

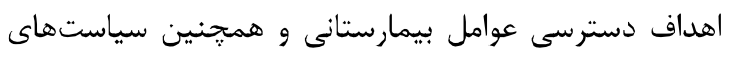

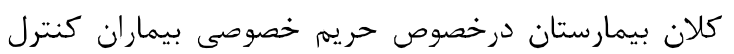

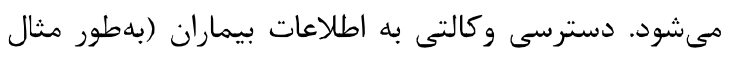

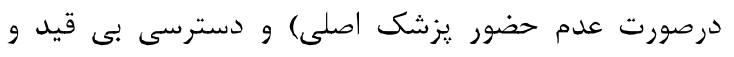
شرط موقت در شرايط اضطر ارى نيز از خصوصيات ديكر مدل

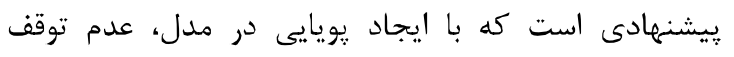

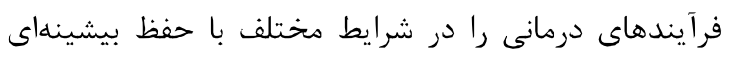

سياستهاى دسترسى و حريم خصوصى ممكن مى دسازد.

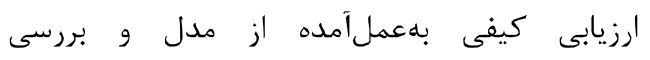

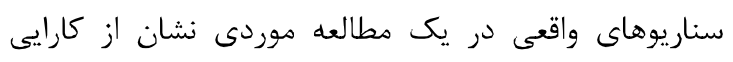

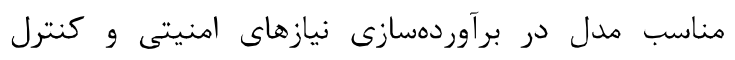

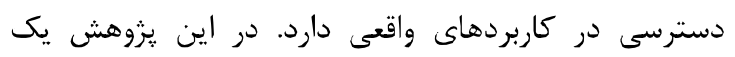

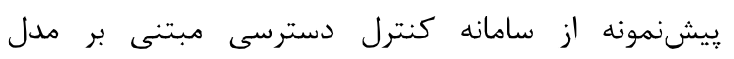

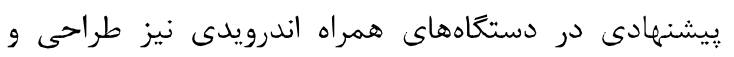

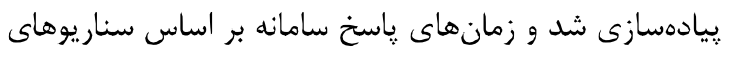

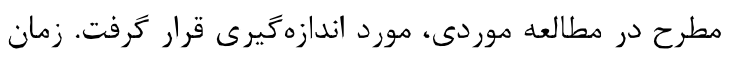

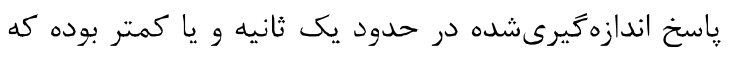

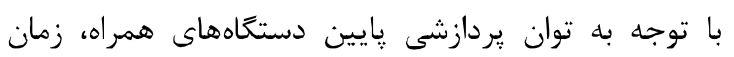

استفاده از اين سامانه در مطالعه موردى و سناريوهاى

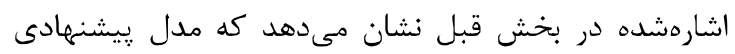

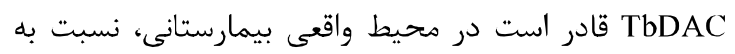

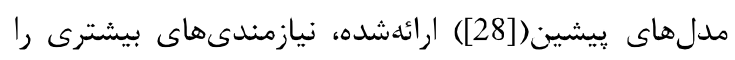

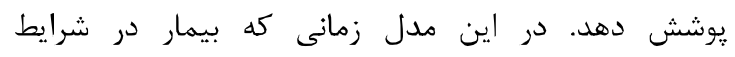

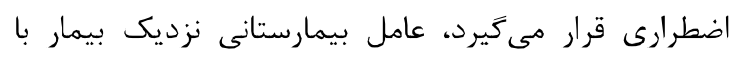

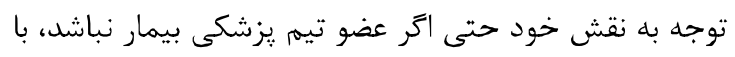

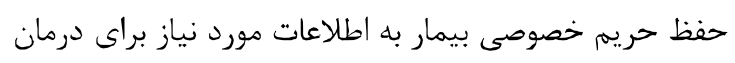

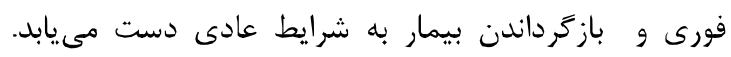

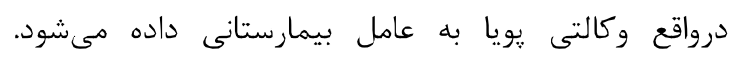

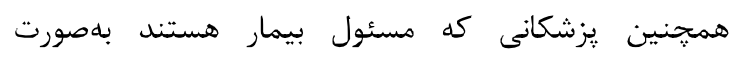

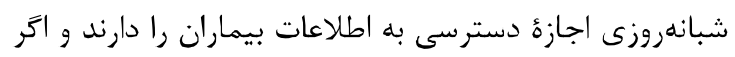

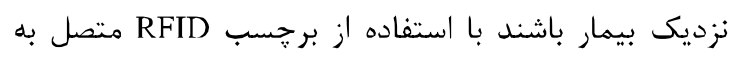

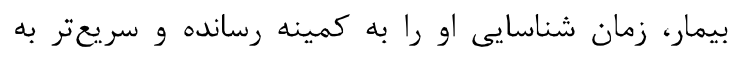

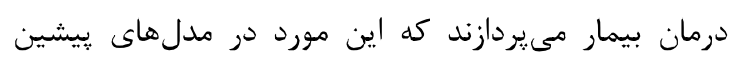
درنظر ترفته نشده بود. زمان قاسخ به درخواست عامل بيمارستانى در اجراى بوداى

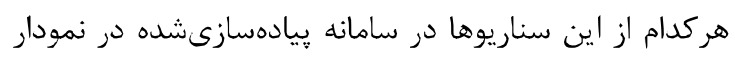

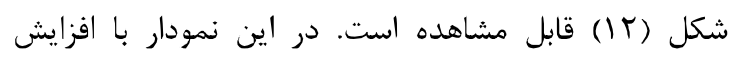
تعداد درخواستها، زمان ياسخ نيز افزايش مى ميابد.

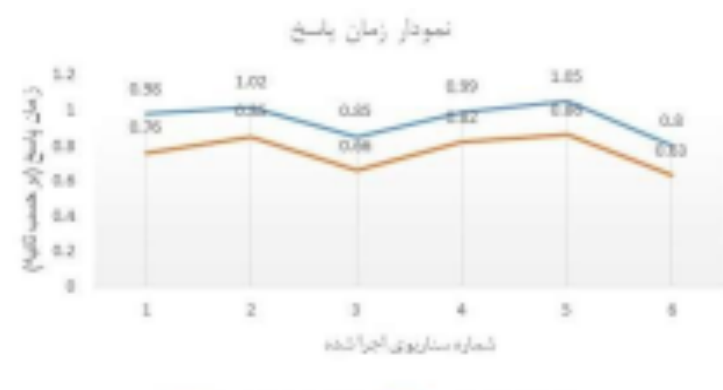

(شكل-r|): نتيجه ارزيابى زمان ياسخ به درخواستها (Figure-12): Evaluation of response times of requests

\section{ه- نتيجه تيرى}

كسترش استفاده از فناورىهاى نوين و بلهيت بهور خاص اينترنت

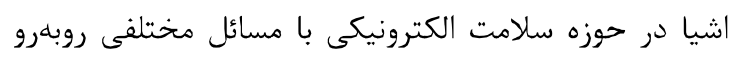

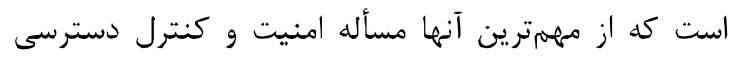
نيازمندى كاى امنيتى مختلفى در سلامت الكترونيكى مطرح

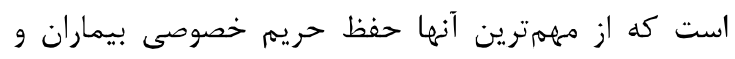

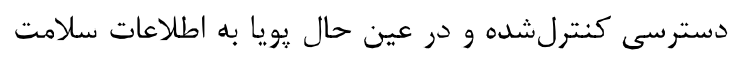
آنها طبق شرايط بيمار است؛ بهطورى كه دسترسى افراد بسته 
Healthcare Informatics Research, vol.1, pp.1951 , Jun2017.

[10] H. S. G. Pussewalage and V. A. Oleshchuk, "An attribute based access control scheme for secure sharing of electronic health records," in Proceedings of $18^{\text {th }}$ IEEE International Conference on e-Health Networking, Applications and Scrvices (Healthcom), Sept.2016, pp.1-6.

[11] M.Sicuranza and A.Esposito, "An access control model for casy management of patient privacy in her systems," in Proceedings of $8^{\text {th }}$ International Conference for Internet Technology and Secured Transactions (ICITST2013), Dec.2013, pp.463-470.

[12] A. Ouaddah, H. Mousannif, A. A. Elkalam, and A. A. Ouahman, "Access control in the internet of things: Big challenges and new opportunities," Computer Networks, vol.112, no.Supplement C, pp.237-262, 2017.

[13] M.F.F.Khan and K.Sakamura, "A secure and flexible e-health access control system with provisions for emergency access overrides and delegation of access privileges," in Proceedings of $18^{\text {th }}$ International Conference on Advanced Communication Technology (ICACT), pp.541546, Jan2016.

[14] M. Jayabalan and T. O’Daniel, "Access control and privilege management in electronic health record: a systematic litcrature revicw," Journal of Medical Systems, vol.40, p.261, Oct2016.

[15] M.F.F.Khan and K.Sakamura, "Context-aware access control for clinical information systems," in Proceedings of 2012 International Conference on Innovations in Information Technology (IIT), March.2012, pp.123-128.

[16] C. K. Georgiadis, I. Mavridis, G. Pangalos, and R. K. Thomas, "Flexible team-based access control using contexts," in Proceedings of the Sixth ACM Symposium on Access Control Models and Technologies, SACMAT'(01, (NewYork, NY, USA), pp.21-27, 2001.

[17] M. Yarmand, K. Sartipi, and D. Down, "Bchavior-based access control for distributed healthcare environment," in Computer-Based Medical Systems, 2008. CBMS'08. 21 ${ }^{\text {st }}$ IEEE International Symposium on, pp.126-131, June2008.

[18] E. Georgakakis, S. Nikolidakis, D. Vergados, and C. Douligeris, "Spatio temporal emergency role based access control (stem-rbac): A time and location aware role based access control model with a break the glass mechanism," in Computers and Communications (ISCC): 2011 IEEE Symposium on, pp. 764-770, June2011.

[19] Q.Ni, A.Trombetta, E.Bertino, andJ.Lobo, "Privacy-aware role based access control," in

$$
\begin{aligned}
& \text { بسيار مناسبى محسوب مىشود. البته بايد توجه داشت كه } \\
& \text { ييادهازى كامل يك سامانه كنترل دسترسى در محيط } \\
& \text { واقعى نيازمند بهره }
\end{aligned}
$$

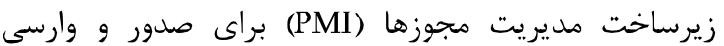

$$
\begin{aligned}
& \text { كواهىهاى نقشها (بهطور مثال كواهى ديجيتالى طبابت يا } \\
& \text { يرستارى از سوى وزارت بهداشت) و وكالتهاى الكترونيكى هونى } \\
& \text { (رسمى و حقوقى) قابل اعطا در اين مدل است. ارايه يك } \\
& \text { طرح عملياتى مناسب بر اساس اين دو زيرساخت با توجه به }
\end{aligned}
$$

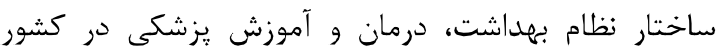

$$
\begin{aligned}
& \text { مىتواند در ادامه اين يثوهش در آينده مدنظر قرار گيرد. }
\end{aligned}
$$

\section{6- References}

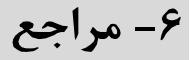

[1] I. B. Ida, A. Jemai, and A. Loukil, "A survey on security of IoT in the context of ehealth and clouds," in Proceedings of $11^{\text {th }}$ International Design Test Symposium (IDT), pp.25-30, Dec2016.

[2] A. J. Jara, A. F. Alcolea, M. A. Zamora, A. F. G. Skarmeta, and M. Alsaedy, "Drugs interaction checker based on iot," in Proceedings of 2010 Internet of Things (IOT), pp.1-8, Nov2010.

[3] A, Kevin, "That 'internet of things' thing," RFID journal, vol. 22, pp.97-114, Jul2009.

[4] D.Lu and T.Liu, "The application of iot in medical systcm," in Proceedings of 2011 IEEE International Symposium on IT in Medicine and Education, vol.1, pp.272-275, Dec2011.

[5] R. Marti, J. Delgado, and X. Perramon, "Security specification and implementation for mobile ehealth services," in Proceedings of 2004 IEEE International Conference on e-Technology, eCommerce and e-Service, March.2004, pp.241248.

[6] F. Rezaeibagha and Y. Mu, "Distributed clinical data sharing via dynamic access-control policy transformation," International Journal of Medical Informatics, vol.89, no.Supplement C, pp.25-31, 2016.

[7] I. lakovidis, "Towards Personal Health Record: Current Situation, Obstacles and Trends in Implementation of Electronic Healthcare Record in Europe," International Journal of Medical Informatics, vol.52, pp.105-115, 1998.

[8] M.Sicuranza, A.Esposito, and M.Ciampi, "A vicw-based access control model for her systems," in Proceedings of Intelligent Distributed Computing VIII, pp.443 452, Springer, 2015.

[9] M. Abomhara, H. Yang, G. M. Køien, and M. B. Lazreg, "Work-based access control model for cooperative healthcare environments: Formal specification and verification," Journal of 


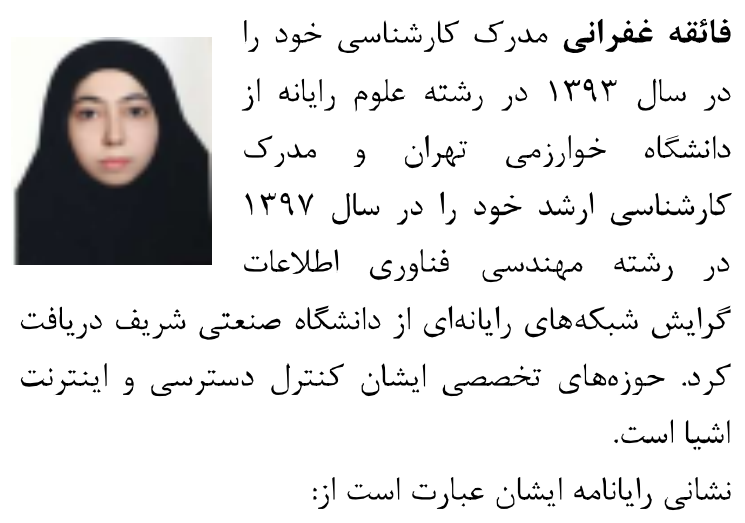

ghofrani@ce.sharif.edu

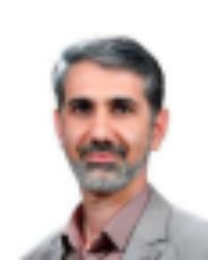

مرتضى امينى دكتراى تخصصى خوه را

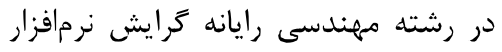

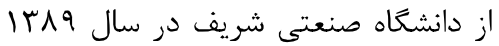
دريافت كرد. ايشان در حال حال حاضئر

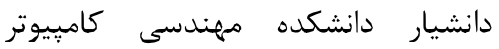
دانشعاه صنعتى شريف و زمينههاى يزروهشى ايشان امنيت

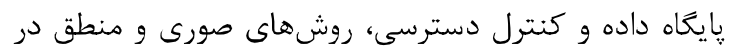

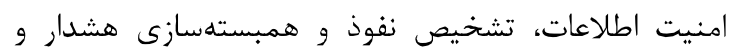
كنترل جريان اطلاعات در اندرويد است. از جمله افتخارات

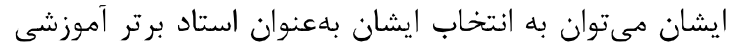
دانشكده مهندسى كامييوتر دانشكاه صنعتى شريف دران در سال

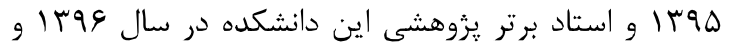

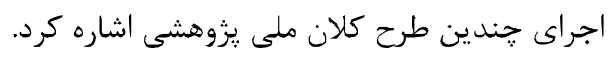

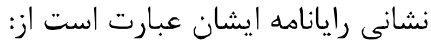

amini@sharif.edu
Proceedings of $12^{\text {th }}$ ACM Symposium on Access Control Models and Technologies, SACMAT '07, pp.41-50, ACM, 2007.

[20] N. Yang, H. Barringer, and N. Zhang, "A purpose-based access control model," in Proceedings of Third International Symposium on Information Assurance and Security, pp.143148, Aug2007.

[21] K. Seol, Y.-G. Kim, E. Lee, Y.-D. Seo, and D.K. Baik, "Privacy preserving attribute-based access control model for XML-based electronic health record system,"' IEEE Access, vol. 6, pp. 9114-9128, 2018.

[22] Majeed, Abdul, "Attribute-centric anonymization scheme for improving user privacy and utility of publishing e-health data," Journal of King Saud University-Computer and Information Sciences, March 2018.

[23] P.Gope and R.Amin, "A novel reference security model with the situation based access policy for accessing ephr data," Journal of Medical Systems, vol.40, p.242, Sep2016.

[24] H. Narayanan and M. Giine, "Ensuring access control in cloud provisioned healthcare systems," in Consumer Communications and Networking Conference (CCNC): 2011 IEEE, Jan.2011, pp.247-251.

[25] US Department of Health and Human Services, "Public Law 104-191: Health Insurance Portability and Accountability Act of 1996," Retrieved November 24 (2003): 2003.

[26] J. Jing, A. Gail-Joon, H. Hongxin, J. Michael, and Z.Xinwen, "Patient-centric authorization framework for electronic healthcare services," computers \& security, vol.30, no.2-3, pp.116127, 2011.

[27] M.A. Doostari, M. Miabi, and M. Momeni, "Proposing a privacy and anonymity protocol in ehealth using public key infrastructure", in Proceedings of the 4th International Conference on Applied Research in Computer Engineering and Signal Processing, Tehran, Iran, 2016.

[TV] [وستارى, محمدعلى؛ مريم ميابى جغال و مسعود

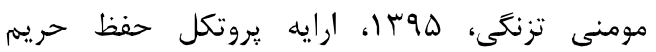

خصوصى و كمنامى در سلامت الكترونيك با استفاده از

زيرساخت كليد عمومى، جهارمين كنفرانس بين المللى

يزوهش هاى كاربردى درمهندسى كامييوتر و يردازش

سيخنال، تهران، دانشگاه صنعتى مالك اشتر - دانشعاه

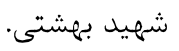

[28] F. hashemibeni, "Privacy preserving access control in iot for ehealth," Master's thesis, Sharif University of Technology, September 2015. 